\title{
VERIFICATION OF THE DEFENSE WASTE PROCESSING FACILITY'S (DWPF) PROCESS DIGESTION METHOD FOR THE SLUDGE BATCH 7B BLEND SAMPLE
}

\author{
D. R. Click \\ T. B. Edwards \\ B.J. Wiedenman
}

August 29, 2011

Analytical Development

Savannah River National Laboratory Aiken, SC 29808

Prepared for the U.S. Department of Energy Under Contract Number DE-AC09-08SR22470

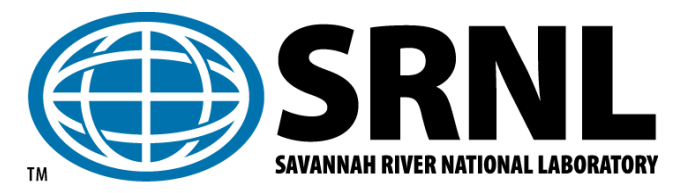


This page intentionally left blank 


\section{DISCLAIMER}

This work was prepared under an agreement with and funded by the U.S. Government. Neither the U.S. Government or its employees, nor any of its contractors, subcontractors or their employees, makes any express or implied:

1. warranty or assumes any legal liability for the accuracy, completeness, or for the use or results of such use of any information, product, or process disclosed;

2. representation that such use or results of such use would not infringe privately owned rights; or

3. endorsement or recommendation of any specifically identified commercial product, process, or service. Any views and opinions of authors expressed in this work do not necessarily state or reflect those of the United States Government, or its contractors, or subcontractors.

Printed in the United States of America

Prepared For

U.S. Department of Energy 
This page intentionally left blank 
Key Words:

method development, analytical process, $S B 7$,

waste compliance

Retention:

Permanent

\title{
VERIFICATION OF THE DEFENSE WASTE PROCESSING FACILITY'S (DWPF) PROCESS DIGESTION METHOD FOR THE SLUDGE BATCH 7B BLEND SAMPLE
}

\author{
D. R. Click
}

T. B. Edwards

B.J. Wiedenman

August 29, 2011

Analytical Development

Savannah River National Laboratory

Aiken, SC 29808

Prepared for the U.S. Department of Energy Under Contract Number DE-AC09-08SR22470

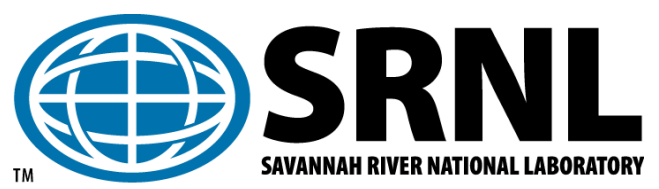




\section{REVIEWS AND APPROVALS}

D.R. Click, Author, Analytical Development, SRNL

T.B. Edwards, C-Author, ACES, SRNL

B.J. Wiedenman, Co-Author, Analytical Development, SRNL

D.P. Lambert, Technical Reviewer, E\&CTP Research Programs, SRNL

C.C. Herman, Manager, DWPF Programs, SRNL

C.M Gregory, Manager, Spectroscopy and Separations, Analytical Development, SRNL Date

J.E. Occhipinti, Manager, Waste Solidification Engineering, SRR
Date

Date
Date

Date
Date

\section{Date}


This page intentionally left blank 


\section{TABLE OF CONTENTS}

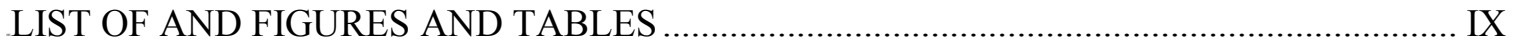

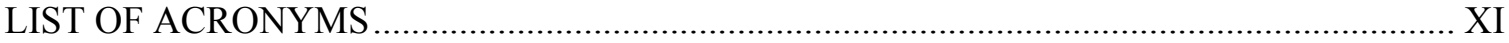

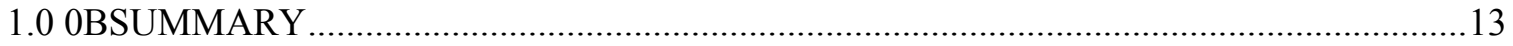

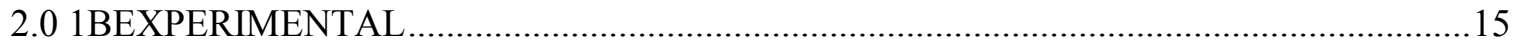

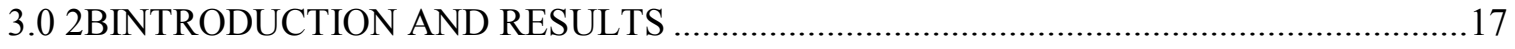

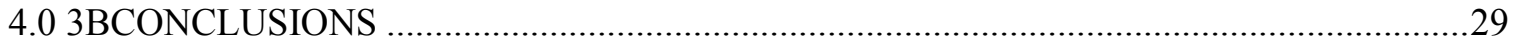

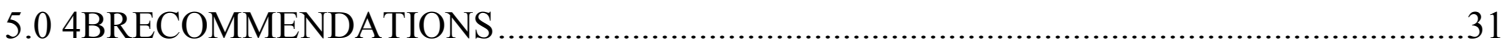

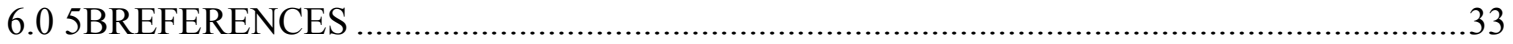

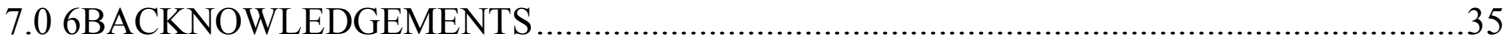

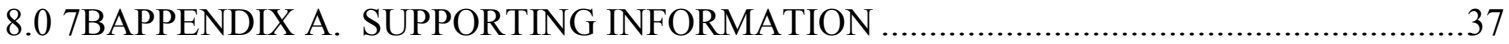


SRNL-STI-2011-00475, REVISION 0

This page intentionally left blank 


\section{LIST OF AND FIGURES AND TABLES}

Table 3-1. Elemental concentrations of SB7b SRAT Receipt radioactive sludge slurry obtained from ICP-AES analysis of Aqua Regia, DWPF Cold Chem method and Sodium Peroxide/Hydroxide Fusion digestions.

Values are presented on a weight percent (wt\%) of total dried solids basis.

Table 3-2 Statistical comparison of Aqua Regia, DWPF Cold Chem method and Sodium Peroxide/Hydroxide Fusion digestions of SB7b SRAT Receipt sludge. Digestion methods not having similar bold font or those that are not underlined are statistically different at the 5\% significance level. The less than sign indicates

the digestion method with the lowest and highest mean concentration from ICP-AES measurements. .....20

Table 3-3. Elemental concentrations of SB7b SRAT Product radioactive sludge slurry obtained from ICP-AES analysis of Aqua Regia, DWPF Cold Chem method and Sodium Peroxide/Hydroxide Fusion digestions. Values are presented on a weight percent $(\mathrm{Wt} \%)$ total dried solids basis.

Table 3-4. Statistical comparison of Aqua Regia, DWPF Cold Chem method and Sodium Peroxide/Hydroxide Fusion digestions of SB7b SRAT Product sludge. Digestion methods not having similar bold font or those that are not underlined are statistically different at the 5\% significance level.

Table 3-5. Elemental concentrations of ARG standard from ICP-AES analysis of Aqua Regia, and Sodium Peroxide/Hydroxide Fusion digestions performed concurrently with SB7b SRAT Receipt Sample. Values are presented on a weight percent $(\mathrm{Wt} \%)$ total solids basis.

Table 3-6. E concentrations of ARG standard from ICP-AES analysis DWPF Cold Chem method digestions performed concurrently with SB7b SRAT Receipt Sample. Values are presented on a weight percent $(\mathrm{Wt} \%)$ total solids basis.

Table 3-7. Elemental concentrations of ARG standard from ICP-AES analysis of Aqua Regia, and Sodium Peroxide/Hydroxide Fusion digestions performed concurrently with SB7b SRAT Product sample. Values are presented on a weight percent $(\mathrm{Wt} \%)$ total solids basis.

Table 3-8. Continuation of elemental concentrations of ARG standard from ICP-AES analysis of Aqua Regia, DWPF Cold Chem method and Sodium Peroxide/Hydroxide Fusion digestions performed concurrently with SB7b SRAT Product sample. Values are presented on a weight percent $(\mathrm{Wt} \%)$ total solids basis.....27 
This page intentionally left blank 


\section{LIST OF ACRONYMS}

$\begin{array}{ll}\text { AD } & \text { Analytical Development } \\ \text { AR } & \text { Aqua Regia } \\ \text { ARG } & \text { Analytical Reference Glass } \\ \text { CC } & \text { Cold Chem } \\ \text { DI } & \text { De-Ionized } \\ \text { DOE } & \text { Department of Energy } \\ \text { DWPF } & \text { Defense Waste Processing Facility } \\ \text { ICP-AES } & \text { Inductively Coupled Plasma - Atomic Emission Spectroscopy } \\ \text { LWO } & \text { Liquid Waste Operations } \\ \text { PF } & \text { Sodium Peroxide/Hydroxide Fusion } \\ \text { SB } & \text { Sludge Batch } \\ \text { SME } & \text { Slurry Mix Evaporator } \\ \text { SRAT } & \text { Sludge Receipt and Adjustment Tank } \\ \text { SRNL } & \text { Savannah River National Laboratory } \\ \text { WAPS } & \text { Waste Acceptance Product Specification }\end{array}$


This page intentionally left blank 
SRNL-STI-2011-00475, REVISION 0

\subsection{SUMMARY}

For each sludge batch that is processed in the Defense Waste Processing Facility (DWPF), the Savannah River National Laboratory (SRNL) performs confirmation of the applicability of the digestion method to be used by the DWPF lab for elemental analysis of Sludge Receipt and Adjustment Tank (SRAT) receipt samples and SRAT product process control samples. DWPF SRAT samples are typically dissolved using a room temperature $\mathrm{HF}-\mathrm{HNO}_{3}$ acid dissolution (i.e., DWPF Cold Chem Method, see DWPF Procedure SW4-15.201) and then analyzed by inductively coupled plasma - atomic emission spectroscopy (ICPAES).

This report contains the results and comparison of data generated from performing the Aqua Regia (AR), Sodium Peroxide/Hydroxide Fusion (PF) and DWPF Cold Chem (CC) method digestions of Sludge Batch $7 b$ (SB7b) SRAT Receipt and SB7b SRAT Product samples. The SB7b SRAT Receipt and SB7b SRAT Product samples were prepared in the SRNL Shielded Cells, and the SRAT Receipt material is representative of the sludge that constitutes the SB7b Blend, the sludge expected to be in Tank 40.

Observations and results from the SRAT Receipt digestions include the following:

- Brown/red solids and white solids remained in the solutions generated from the CC digestion after all acid addition steps and dilutions were performed. The brown/red colored solids eventually dissolved.

- A statistically larger average $\mathrm{Al}$ concentration is seen in the PF digestions compared to the $\mathrm{AR}$ and $\mathrm{CC}$ methods with an $\sim 3 \%$ and an $\sim 6 \%$ relative difference in the means, respectively.

- There is not a statistical difference in the means for Th between the AR and PF digestion results but a statistical difference in the means is noted between the mean of the $\mathrm{CC}$ digestions and the $\mathrm{AR}$ and PF means with an $\sim 22 \%$ and an $\sim 16 \%$ relative difference in the means, respectively.

- A statistical difference in the means is noted for $U$ between the PF results compared to the AR and $\mathrm{CC}$ results. The PF mean is $\sim 5 \%$ lower than the $\mathrm{AR}$ results and $\sim 7 \%$ lower than the $\mathrm{CC}$ result.

- A statistical difference of means is noted for the minor elements $\mathrm{Cr}, \mathrm{Cu}, \mathrm{K}, \mathrm{Li}, \mathrm{Mg}, \mathrm{Ti}$ and $\mathrm{Zr}$ between two or more of the digestion methods.

- There is not a statistical difference in the means for $\mathrm{Fe}, \mathrm{Mn}$, or $\mathrm{Ni}$, nor is there a statistical difference in the mean $\mathrm{Na}$ concentration obtained by the AR and $\mathrm{CC}$ digestion methods.

Observations and results from the SRAT Product digestions include the following:

- Brown/red solids and white solids remained in the solutions generated from the CC digestion after all acid addition steps and dilutions were performed. The brown/red colored solids eventually dissolved.

- A statistically larger average $\mathrm{Al}$ concentration is seen in the PF digestions compared to the $\mathrm{AR}$ and $\mathrm{CC}$ methods with an $\sim 2 \%$ and an $\sim 7 \%$ relative difference in the means, respectively.

- $\quad$ There is not a statistical difference in the means for Th between the AR and PF digestion results but a statistical difference in the means is noted between the mean of the CC digestions and the $\mathrm{AR}$ and $\mathrm{PF}$ means with an $\sim 26 \%$ and an $\sim 18 \%$ relative difference in the means, respectively.

- A statistical difference of means is noted for the minor elements $\mathrm{Cu}, \mathrm{K}$, Ti and $\mathrm{Zr}$ between two or more of the digestion methods.

- There is not a statistical difference in the means for $\mathrm{Cr}, \mathrm{Fe}, \mathrm{Li}, \mathrm{Mg}, \mathrm{Mn}, \mathrm{Ni}$, or $\mathrm{U}$, nor is there a statistical difference in the mean $\mathrm{Na}$ concentration obtained by the $\mathrm{AR}$ and $\mathrm{CC}$ digestion methods. 
Based on the results from performing three different digestion methods on SB7b sludge slurry, SRNL notes and recommends the following:

- The results from using the DWPF CC method to digest SB7b sludge slurry appear, in most cases, to be equivalent to the AR and PF digestion methods. However, Al and Th should be analyzed by the peroxide fusion method for SB7b. Visual observations indicate Fe and Mn may not be completely dissolving in the initial dilution of the sample before the final dilution is performed. For this data set, very small relative differences between the digestion methods are noted and no statistical difference is observed between the digestion methods for Fe and Mn. However, we recommend that the $\mathrm{Fe}$ and $\mathrm{Mn}$ concentration be determined using both digestion methods (CC and PF) for SB7b sludge slurry and the highest concentration between the two digestions should be used. Although $\mathrm{K}$ is a minor element, large relative differences are noted in this report between the different digestions and the DWPF should also monitor the K concentration.

- The DWPF CC method was originally developed to be used for SME analyses. Given continuous visual observations of solids in the CC digestions both at SRNL and DWPF, potential issues with accurate $\mathrm{Al}$ measurements when processing $\mathrm{HM}$ waste, and difficulty measuring Th accurately due to the limited solubility of Th in HF matrices, SRNL recommends that the DWPF consider a different digestion scheme that relieves some of these issues.

- The DWPF CC results from this study indicate Al and Th do not completely dissolve or precipitate as fluoride salts. Visual observations also indicate $\mathrm{Fe}$ and $\mathrm{Mn}$ may not completely dissolve using the DWPF CC method. Therefore, DWPF should consider and monitor the impact of these elements on SB7b blending operations conducted at DWPF via comparison of SRAT and SME analyses. If a consistent difference in elemental concentrations is revealed, another type of digestion (i.e. sodium peroxide/hydroxide fusion) should be used to determine the concentration of the element in question. Particular emphasis should be placed on monitoring Al, Fe, Mn, K, and Th concentrations in SB7b. 
SRNL-STI-2011-00475, REVISION 0

\subsection{EXPERIMENTAL}

The SB7b sample used for this study was the SB7b SRAT Receipt sample comprised of the following; Tank 7 sludge from sample FTF-07-11-3, Tank 51 sludge from sample HTF-51-11-28 (the Sludge Batch 7a confirmation sample), $\mathrm{H}$ Canyon Pu solution, and a salt solution were combined to produce a slurry with a composition to match Tank Farm projections of April 27, 2011. The material was not in the multiple steps washed as the Tank Farm would wash due to schedule constraints; instead, one "Wash", using the salt solution, was used to produce the slurry. Then, the Tank 7/Tank 51 mixture was combined with the Sludge Batch 7a Tank 40 Waste Acceptance Product Specification sample (HTF-40-11-66) to produce the SB7b. The blended sample was 71\% Tank 40, 29\% Tank 7/Tank 51 measured on an insoluble solids basis. The blend represented the highest projected Tank 40 heel (as of May 25, 2011) for the planned SB7b transfer.

The sludge samples were dissolved in quadruplicate in the SRNL Shielded Cells facility in a manner similar to the DWPF CC method, and by PF and AR digestion. For detailed steps of the PF digestion, see ADS procedure $2502 .{ }^{1}$ For detailed steps of the AR digestion, see ADS procedure $2226 .{ }^{2}$ Three replicate dissolutions of the analytical reference glass (ARG) standard were performed concurrently with each set of digestions for quality control purposes. The ARG results are then evaluated by comparing the measured results against a two sigma variation of the standard deviation associated with measured concentrations obtained from a round-robin consensus study. For the SRAT Receipt material, B, Si, Ti, and $\mathrm{Zr}$ (as expected) were low and flagged for being outside of the 2 sigma limits for the AR digestions. $\mathrm{Ca}$ was flagged for being outside the 2 sigma limits (slightly high) for the PF digestions. Ca and Fe were flagged for being outside the 2 sigma limits (slightly high) for the $\mathrm{CC}$ digestions. For the SRAT product material, Al, B, Si, Ti and $\mathrm{Zr}$ (as expected) were flagged for being outside of the 2 sigma limits for the $\mathrm{AR}$ digestions. All elements were within the 2 sigma limits for the $\mathrm{CC}$ digestions. Ca was flagged for being outside of the 2 sigma limits for the PF digestions. Additional quality control measures included ICP-AES analyses of a multi-element standard as a check for ICP-AES accuracy independent of digestions. Elements in this standard included Al, Fe, Mn, Ni, Na and $\mathrm{S}$. All measured values were within $15 \%$ of the known concentrations for these elements in the standard analyzed concurrently with the $\mathrm{PF}$ and AR digestions.

The CC method digestion (see DWPF Procedure SW4-15.201) involved adding $25 \mathrm{~mL}$ of concentrated HF to radioactive sludge slurry $(\sim 3.5 \mathrm{~g}$ for the SRAT Receipt at $16.05 \mathrm{wt} \%$ total solids and $\sim 3.5 \mathrm{~g}$ for the SRAT Product at $23.6 \mathrm{wt} \%$ total solids) and stirring for $1 \mathrm{hr}$. Then, $25 \mathrm{~mL}$ of concentrated $\mathrm{HNO}_{3}$ was added and the mixture was stirred for an additional 30 minutes. Undissolved brown/red solids remained in each digestion bottle after the acid addition was complete. Each sample was then diluted with deionized (DI) water to $250 \mathrm{~mL}$ in a pre-weighed volumetric flask. The density of the solution was obtained from the weight of the $250 \mathrm{~mL}$ of solution. Approximately $15 \mathrm{~g}$ of solution was taken from the $250 \mathrm{~mL}$ volumetric flask and added to a $100 \mathrm{~mL}$ volumetric flask and subsequently diluted with DI water. Over time, all of the brown solids dissolved into the solution but white insoluble/precipitated solids remained. No attempt to recover the solids was made. 
This page intentionally left blank 
SRNL-STI-2011-00475, REVISION 0

\subsection{INTRODUCTION AND RESULTS}

The DWPF is currently processing and immobilizing radioactive sludge slurry into a durable borosilicate glass. The DWPF has already processed seven sludge batches (Sludge Batch 1A, Sludge Batch 1B, Sludge Batch 2, Sludge Batch 3, Sludge Batch 4, Sludge Batch 5, Sludge Batch 6) and is currently processing an eighth (Sludge Batch 7a). A sludge batch is defined as a single tank of sludge or a combination of sludges from different tanks that has been or will be qualified before being transferred to DWPF. Thus, following the sludge batch preparation plan of the Liquid Waste Organization (LWO), the qualified sludge in Tank 51 is to be blended with the heel of the previous sludge batch in Tank 40 (referred to as a "blend" composition in sludge batch planning). The sludge being qualified at the SRNL is the "blend" sample, a sludge sample that has been blended with Tank 40 material representing the heel of the previous sludge batch. The next batch of radioactive sludge slurry to be processed by the DWPF is SB7b.

The statistical results of the SB7b samples generated from this study are provided in Table A1 of Appendix A. The results from each type of digestion are summarized in Table 3-1 for the SRAT Receipt and Table 3-3 for the SRAT Product samples. The ICP-AES results of the seventeen elements that are analyzed by the DWPF lab are presented on a weight percent ( $\mathrm{wt} \%$ ) of total solids basis. A statistical comparison of the means from the SRAT Receipt and SRAT Product for all three digestions could not be performed for $\mathrm{B}, \mathrm{Ca}, \mathrm{Na}, \mathrm{Si}$ or $\mathrm{Zr}$. B was less than the detection limit in the AR and PF digestions and B is leached from the borosilicate spray chamber of the ICP-AES instrument due to the presence of HF in the $\mathrm{CC}$ digestions and is therefore not reported. $\mathrm{Ca}$ is a contaminant in the PF reagents and is not included in the means with the $\mathrm{AR}$ and $\mathrm{CC}$ digestions for comparison. $\mathrm{Na}$ is added as part of the reagents used for PF digestions so only the means of the $\mathrm{CC}$ and AR digestions were compared. Si is leached from the ICP-AES instrument due to the presence of HF in the CC digestions and $\mathrm{Si}$ is known to not dissolve well in AR digestions. Thus, the Si value obtained from the PF data was used. $\mathrm{Zr}$ could not be included in a statistical comparison of all the means because the PF digestion utilizes a $\mathrm{Zr}$ crucible; therefore, only the AR and $\mathrm{CC}$ results were compared. However, the $\mathrm{Zr}$ result from the AR digestions was low. $\mathrm{Zr}$ dissolves better when HF is present and this can readily be seen from the ARG-1 analysis results. In addition, for the SRAT Receipt, the K concentrations could not be compared because $\mathrm{K}$ was less than the minimum detection limit in all three digestions and for the SRAT product sample, the potassium concentration was less than the minimum detection limit in the CC digestion solutions.

Statistical comparisons of the data from the three digestion methods (for $\mathrm{B}, \mathrm{Na}, \mathrm{Si}$ and $\mathrm{Zr}$ there are only two digestion methods) are provided in Exhibit A1 in Appendix A. The results were generated using JMP Version 7.0.2. ${ }^{3}$ The plots of this exhibit show a 95\% confidence interval for the mean (a mean diamond) of each set of measurements. For each element, the mean concentration of the samples by each digestion method is provided, and means that are not connected by the same letter in the listing of the exhibit are significantly different at a significance level of 5\%. For example, consider the SRAT Receipt $\mathrm{Al}$ measurements. The results of the exhibit indicate that the mean of the PF results differs from the mean of the CC results. The exhibit also indicates the means for the $\mathrm{CC}$ results and the AR results are not statistically different and the means from the AR results and the PF results are not statistically different.

For the $\mathrm{B}, \mathrm{Na}, \mathrm{Si}, \mathrm{Zr}$ comparisons, the JMP output from an analysis of variance of the measurements for two digestions is provided, and only the $95 \%$ confidence mean diamond of each digestion is shown. Overlap marks show for each diamond, and overlap marks in one diamond that are closer to the mean of another diamond than that diamond's overlap marks indicate that those two groups are not different at the $95 \%$ confidence level. The visual comparisons are supported by an F test that compares the means of the $\mathrm{AR}$ and $\mathrm{CC}$ digestions for $\mathrm{Na}$ and $\mathrm{Zr}$ and the means of the $\mathrm{AR}$ and $\mathrm{PF}$ digestions for $\mathrm{B}$ and $\mathrm{Si}$. If the $\mathrm{p}$ value is less than 0.05 , then the means are statistically different at the $5 \%$ level. From Exhibit A1, there is 
no statistical difference in the AR and CC means for Na for the SRAT Product or the SRAT Receipt samples.

Summaries of the statistical comparisons of Exhibit A1 are shown in Table 3-2 and Table 3-4. Digestion methods not having the same bold font or those that are not underlined are statistically different at the 5\% significance level. The less than sign indicates the digestion method with the lowest and highest mean concentration from ICP-AES measurements. Tables 3-5 through 3-8 contain the ARG-1 digestion results from the three digestion methods with a relative comparison to the known concentration of specific elements in the ARG-1 glass.

During verification of the DWPF CC method for previous sludge batches, boehmite $(\mathrm{AlO}(\mathrm{OH}))$, muscovite $(\mathrm{K}, \mathrm{Na})(\mathrm{Al}, \mathrm{Mg}, \mathrm{Fe})_{2}\left(\mathrm{Si}_{3.1} \mathrm{Al}_{0.9}\right) \mathrm{O}_{10}(\mathrm{OH})_{2}$, silicon dioxide $\left(\mathrm{SiO}_{2}\right)$, dipotassium sodium aluminum fluoride $\left(\mathrm{K}_{2} \mathrm{NaAl}_{3} \mathrm{~F}_{12}\right)$, dipotassium aluminum pentafluoride $\left(\mathrm{K}_{2} \mathrm{AlF}_{5}\right)$, aluminum fluoride $\left(\mathrm{AlF}_{3}\right)$, chiolite $\left(\mathrm{Na}_{5} \mathrm{Al}_{3} \mathrm{~F}_{14}\right)$, cryolite $\left(\mathrm{Na}_{3} \mathrm{AlF}_{6}\right)$, sodium magnesium aluminum hexafluoride $\left.(\mathrm{NaMgAlF})_{6}\right)$, iron zirconium hexafluoride $\left(\mathrm{FeZrF}_{6}\right)$, disodium iron aluminum heptafluoride $\left(\mathrm{Na}_{2} \mathrm{FeAlF}_{7}\right)$, and calcium thorium fluoride $\left(\mathrm{Ca}_{0.5} \mathrm{Th}_{0.5} \mathrm{~F}_{3}\right)$ have been found. ${ }^{4}$ Due to the radioactivity of the samples, no attempt to recover the solids was made. 
Table 3-1. Elemental concentrations of SB7b SRAT Receipt radioactive sludge slurry obtained from ICPAES analysis of Aqua Regia, DWPF Cold Chem method and Sodium Peroxide/Hydroxide Fusion digestions. Values are presented on a weight percent $(w t \%)$ of total dried solids basis.

\begin{tabular}{|c|c|c|c|c|c|c|}
\hline $\begin{array}{c}\text { Digestion } \\
\text { Method } \rightarrow\end{array}$ & \multicolumn{2}{|c|}{ Aqua Regia } & \multicolumn{2}{c|}{$\begin{array}{c}\mathrm{Na}_{2} \mathrm{O}_{2} / \mathrm{NaOH} \\
\text { Fusion }\end{array}$} & \multicolumn{2}{c|}{ DWPF Cold Chem } \\
\hline Element & Avg Wt\% & $\% \mathrm{RSD}^{\#}$ & Avg Wt\% & $\% \mathrm{RSD}^{\#}$ & Avg Wt\% & $\% \mathrm{RSD}^{\#}$ \\
\hline $\mathrm{Al}$ & $8.48 \mathrm{E}+00$ & $3.8 \mathrm{E}+00$ & $8.83 \mathrm{E}+00$ & $3.0 \mathrm{E}-01$ & $8.14 \mathrm{E}+00$ & $2.6 \mathrm{E}+00$ \\
\hline $\mathrm{B}$ & $<8.17 \mathrm{E}-03$ & NA & $<8.10 \mathrm{E}-02$ & NA & NA & NA \\
\hline $\mathrm{Ca}$ & $6.38 \mathrm{E}-01$ & $4.7 \mathrm{E}+00$ & $7.53 \mathrm{E}-01$ & $2.5 \mathrm{E}+00$ & $6.62 \mathrm{E}-01$ & $1.7 \mathrm{E}+00$ \\
\hline $\mathrm{Cr}$ & $4.31 \mathrm{E}-02$ & $5.8 \mathrm{E}+00$ & $6.04 \mathrm{E}-02$ & $2.2 \mathrm{E}+01$ & $4.44 \mathrm{E}-02$ & $2.6 \mathrm{E}+00$ \\
\hline $\mathrm{Cu}$ & $8.00 \mathrm{E}-02$ & $5.2 \mathrm{E}+00$ & $4.87 \mathrm{E}-02$ & $5.6 \mathrm{E}+00$ & $4.44 \mathrm{E}-02$ & $6.7 \mathrm{E}-01$ \\
\hline $\mathrm{Fe}$ & $1.42 \mathrm{E}+01$ & $4.5 \mathrm{E}+00$ & $1.43 \mathrm{E}+01$ & $1.5 \mathrm{E}-14$ & $1.45 \mathrm{E}+01$ & $3.5 \mathrm{E}-01$ \\
\hline $\mathrm{K}$ & $<2.58 \mathrm{E}-02$ & NA & $<2.56 \mathrm{E}-01$ & NA & $<1.89 \mathrm{E}-01$ & NA \\
\hline $\mathrm{Li}$ & $2.65 \mathrm{E}-02$ & $5.6 \mathrm{E}+00$ & $2.34 \mathrm{E}-02$ & $2.5 \mathrm{E}+00$ & $2.50 \mathrm{E}-02$ & $1.7 \mathrm{E}+00$ \\
\hline $\mathrm{Mg}$ & $2.85 \mathrm{E}-01$ & $4.8 \mathrm{E}+00$ & $2.77 \mathrm{E}-01$ & $9.6 \mathrm{E}-01$ & $2.96 \mathrm{E}-01$ & $3.2 \mathrm{E}-01$ \\
\hline $\mathrm{Mn}$ & $3.02 \mathrm{E}+00$ & $4.8 \mathrm{E}+00$ & $2.98 \mathrm{E}+00$ & $3.4 \mathrm{E}-01$ & $3.12 \mathrm{E}+00$ & $3.1 \mathrm{E}-01$ \\
\hline $\mathrm{Na}$ & $1.41 \mathrm{E}+01$ & $4.5 \mathrm{E}+00$ & NA & NA & $1.46 \mathrm{E}+01$ & $3.4 \mathrm{E}-01$ \\
\hline $\mathrm{Ni}$ & $2.94 \mathrm{E}+00$ & $4.6 \mathrm{E}+00$ & $2.95 \mathrm{E}+00$ & $3.9 \mathrm{E}-01$ & $2.98 \mathrm{E}+00$ & $3.4 \mathrm{E}-01$ \\
\hline $\mathrm{Si}$ & $4.72 \mathrm{E}-01$ & $1.9 \mathrm{E}+01$ & $1.06 \mathrm{E}+00$ & $5.5 \mathrm{E}-01$ & NA & NA \\
\hline $\mathrm{Th}$ & $1.04 \mathrm{E}+00$ & $4.8 \mathrm{E}+00$ & $9.56 \mathrm{E}-01$ & $3.2 \mathrm{E}+00$ & $7.61 \mathrm{E}-01$ & $9.6 \mathrm{E}+00$ \\
\hline $\mathrm{Ti}$ & $1.69 \mathrm{E}-02$ & $5.2 \mathrm{E}+00$ & $1.97 \mathrm{E}-02$ & $7.8 \mathrm{E}-01$ & $1.93 \mathrm{E}-02$ & $7.4 \mathrm{E}+00$ \\
\hline $\mathrm{U}$ & $4.77 \mathrm{E}+00$ & $3.7 \mathrm{E}+00$ & $4.45 \mathrm{E}+00$ & $1.3 \mathrm{E}+00$ & $4.98 \mathrm{E}+00$ & $5.7 \mathrm{E}-01$ \\
\hline $\mathrm{Zr}$ & $1.39 \mathrm{E}-01$ & $1.7 \mathrm{E}+01$ & NA & NA & $2.70 \mathrm{E}-01$ & $8.8 \mathrm{E}-01$ \\
\hline
\end{tabular}

Averages are based upon four replicate dissolutions and ICP-AES determinations except the Peroxide Fusion averages which are based upon three replicate dissolutions and ICP-AES measurements. NA $=$ Not Applicable. ${ }^{\#} \%$ RSD is the percent relative standard deviation for the measurements. 
Table 3-2 Statistical comparison of Aqua Regia, DWPF Cold Chem method and Sodium Peroxide/Hydroxide Fusion digestions of SB7b SRAT Receipt sludge. Digestion methods not having similar bold font or those that are not underlined are statistically different at the $5 \%$ significance level. The less than sign indicates the digestion method with the lowest and highest mean concentration from ICP-AES measurements.

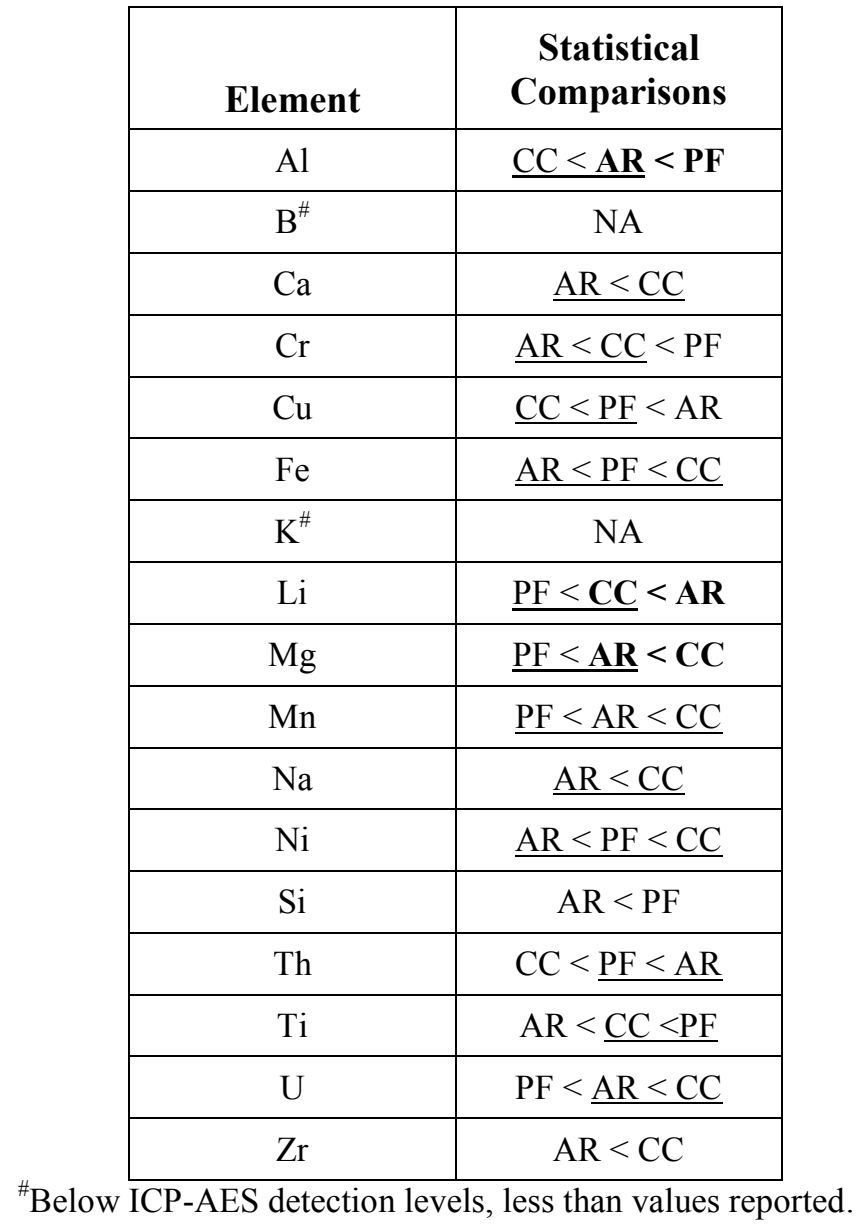

For the SRAT Receipt sample:

- Brown/red solids and white solids remained in the solutions generated from the CC digestion after all acid addition steps and dilutions were performed. The brown/red colored solids eventually dissolved.

- A statistically larger average Al concentration is seen in the PF digestions compared to the $\mathrm{AR}$ and $\mathrm{CC}$ methods with an $\sim 3 \%$ and an $\sim 6 \%$ relative difference in the means, respectively.

- There is not a statistical difference in the means for Th between the AR and PF digestions but a statistical difference in the means is noted comparing $\mathrm{CC}$ digestions to the $\mathrm{AR}$ and $\mathrm{PF}$ means with an $\sim 22 \%$ and an $\sim 16 \%$ relative difference in the means, respectively.

- A statistical difference in the means is noted for $U$ between the PF results compared to the AR and $\mathrm{CC}$ results. The PF results are $\sim 5 \%$ lower than the $\mathrm{AR}$ results, and $\sim 7 \%$ lower than the $\mathrm{CC}$ results.

- A statistical difference of means is noted for the minor elements $\mathrm{Cr}, \mathrm{Cu}, \mathrm{K}, \mathrm{Li}, \mathrm{Mg}, \mathrm{Ti}$ and $\mathrm{Zr}$.

- There is not a statistical difference in the means for $\mathrm{Fe}, \mathrm{Mn}$, or Ni, nor is there a statistical difference in the mean $\mathrm{Na}$ concentration from the $\mathrm{AR}$ and $\mathrm{CC}$ digestions. 
Table 3-5 through Table 3-8 contain the ICP-AES measured weight percent elemental results from digestion of the ARG standard performed concurrently with the SB7b SRAT samples to determine if the dissolutions were complete and the resulting analyses accurate. A statistical comparison of means from the results of digesting the glass standard (ARG-1) by all three methods was not performed due to the small number of observations. However, relative differences are listed in Tables 3-5 through 3-8. For the $\mathrm{AR}$ digestions, $\mathrm{Cu}$ and $\mathrm{Ti}$ were the only elements with a relative difference greater than $10 \%$ compared to the known concentration of $\mathrm{Cu}$ and $\mathrm{Ti}$ in the ARG-1 standard. The $\mathrm{Cu}$ concentration reported was close to the ICP-AES detection limit which explains the large relative difference. $\mathrm{Si}$ and $\mathrm{Zr}$ are not considered because the means of these elements are expected to be greater than $10 \%$ different. For the PF digestions, the $\mathrm{Ca}$ and $\mathrm{Cr}$ means were greater than $10 \%$ different than the known concentrations in ARG-1. Ca is a contaminant in the $\mathrm{PF}$ reagents. For the $\mathrm{CC}$ digestions, $\mathrm{Ca}, \mathrm{Cr}$, and $\mathrm{Cu}$ had means greater than $10 \%$ different than the known concentrations in ARG-1 standard.

Table 3-3 contains the elemental concentrations of the SB7b SRAT Product sample.

Table 3-3. Elemental concentrations of SB7b SRAT Product radioactive sludge slurry obtained from ICPAES analysis of Aqua Regia, DWPF Cold Chem method and Sodium Peroxide/Hydroxide Fusion digestions. Values are presented on a weight percent $(\mathrm{Wt} \%)$ total dried solids basis.

\begin{tabular}{|c|c|c|c|c|c|c|}
\hline $\begin{array}{c}\text { Digestion } \\
\text { Method } \rightarrow\end{array}$ & \multicolumn{2}{|c|}{ Aqua Regia } & \multicolumn{2}{c|}{$\begin{array}{c}\mathrm{Na}_{2} \mathrm{O}_{2} / \mathrm{NaOH} \\
\text { Fusion }\end{array}$} & \multicolumn{2}{c|}{ DWPF Cold Chem } \\
\hline Element & Avg Wt\%* & $\% \mathrm{RSD}^{\#}$ & Avg Wt\%* & $\% \mathrm{RSD}^{\#}$ & Avg Wt\%* & $\% \mathrm{RSD}^{\#}$ \\
\hline $\mathrm{Al}$ & $7.65 \mathrm{E}+00$ & $2.9 \mathrm{E}+00$ & $8.49 \mathrm{E}+00$ & $1.3 \mathrm{E}+00$ & $8.22 \mathrm{E}+00$ & $5.7 \mathrm{E}+00$ \\
\hline $\mathrm{B}$ & $<7.97 \mathrm{E}-03$ & $\mathrm{NA}$ & $<1.74 \mathrm{E}-02$ & NA & NA & NA \\
\hline $\mathrm{Ca}$ & $6.13 \mathrm{E}-01$ & $4.0 \mathrm{E}+00$ & $7.60 \mathrm{E}-01$ & $5.3 \mathrm{E}+00$ & $6.20 \mathrm{E}-01$ & $4.6 \mathrm{E}+00$ \\
\hline $\mathrm{Cr}$ & $4.08 \mathrm{E}-02$ & $4.3 \mathrm{E}+00$ & $4.56 \mathrm{E}-02$ & $3.0 \mathrm{E}+00$ & $4.49 \mathrm{E}-02$ & $7.0 \mathrm{E}+00$ \\
\hline $\mathrm{Cu}$ & $4.03 \mathrm{E}-02$ & $3.9 \mathrm{E}+00$ & $4.36 \mathrm{E}-02$ & $1.7 \mathrm{E}+00$ & $4.00 \mathrm{E}-02$ & $4.3 \mathrm{E}+00$ \\
\hline $\mathrm{Fe}$ & $1.37 \mathrm{E}+01$ & $3.5 \mathrm{E}+00$ & $1.36 \mathrm{E}+01$ & $8.2 \mathrm{E}-01$ & $1.38 \mathrm{E}+01$ & $5.3 \mathrm{E}+00$ \\
\hline $\mathrm{K}$ & $5.51 \mathrm{E}-02$ & $5.1 \mathrm{E}+00$ & $2.89 \mathrm{E}-01$ & $1.3 \mathrm{E}+01$ & $<1.29 \mathrm{E}-01$ & NA \\
\hline $\mathrm{Li}$ & $2.53 \mathrm{E}-02$ & $4.3 \mathrm{E}+00$ & $2.50 \mathrm{E}-02$ & $4.2 \mathrm{E}+00$ & $2.65 \mathrm{E}-02$ & $7.4 \mathrm{E}+00$ \\
\hline $\mathrm{Mg}$ & $2.78 \mathrm{E}-01$ & $3.9 \mathrm{E}+00$ & $2.74 \mathrm{E}-01$ & $1.3 \mathrm{E}+00$ & $2.93 \mathrm{E}-01$ & $4.9 \mathrm{E}+00$ \\
\hline $\mathrm{Mn}$ & $2.94 \mathrm{E}+00$ & $3.6 \mathrm{E}+00$ & $2.97 \mathrm{E}+00$ & $1.0 \mathrm{E}+00$ & $3.02 \mathrm{E}+00$ & $5.2 \mathrm{E}+00$ \\
\hline $\mathrm{Na}$ & $1.49 \mathrm{E}+01$ & $3.7 \mathrm{E}+00$ & NA & NA & $1.51 \mathrm{E}+01$ & $4.8 \mathrm{E}+00$ \\
\hline $\mathrm{Ni}$ & $2.81 \mathrm{E}+00$ & $3.6 \mathrm{E}+00$ & $2.76 \mathrm{E}+00$ & $1.0 \mathrm{E}+00$ & $2.82 \mathrm{E}+00$ & $5.2 \mathrm{E}+00$ \\
\hline $\mathrm{Si}$ & $4.21 \mathrm{E}-01$ & $1.9 \mathrm{E}+01$ & $1.07 \mathrm{E}+00$ & $1.0 \mathrm{E}+00$ & NA & NA \\
\hline $\mathrm{Th}$ & $1.06 \mathrm{E}+00$ & $3.7 \mathrm{E}+00$ & $9.39 \mathrm{E}-01$ & $5.5 \mathrm{E}+00$ & $7.27 \mathrm{E}-01$ & $1.3 \mathrm{E}+01$ \\
\hline $\mathrm{Ti}$ & $1.58 \mathrm{E}-02$ & $3.7 \mathrm{E}+00$ & $1.90 \mathrm{E}-02$ & $2.4 \mathrm{E}+00$ & $1.49 \mathrm{E}-02$ & $2.5 \mathrm{E}+00$ \\
\hline $\mathrm{U}$ & $4.48 \mathrm{E}+00$ & $3.7 \mathrm{E}+00$ & $4.26 \mathrm{E}+00$ & $3.0 \mathrm{E}+00$ & $4.51 \mathrm{E}+00$ & $4.0 \mathrm{E}+00$ \\
\hline $\mathrm{Zr}$ & $1.50 \mathrm{E}-01$ & $1.2 \mathrm{E}+01$ & NA & NA & $2.54 \mathrm{E}-01$ & $6.1 \mathrm{E}+00$ \\
\hline
\end{tabular}

*Averages are based upon four replicate dissolutions and ICP-AES determinations except the Peroxide Fusion averages which are based upon three replicate dissolutions and ICP-AES measurements. NA $=$ Not Applicable.. ${ }^{\#} \% \mathrm{RSD}$ is the percent relative standard deviation for the measurements

A statistical comparison of means from SB7b SRAT product digestions is presented in Table 3-4. 
Table 3-4. Statistical comparison of Aqua Regia, DWPF Cold Chem method and Sodium Peroxide/Hydroxide Fusion digestions of SB7b SRAT Product sludge. Digestion methods not having similar bold font or those that are not underlined are statistically different at the $5 \%$ significance level. The less than sign indicates the digestion method with the lowest and highest mean concentration from ICP-AES measurements.

\begin{tabular}{|c|c|}
\hline & Statistical \\
\hline Element & Comparisons \\
\hline $\mathrm{Al}$ & $\underline{\mathrm{AR}<\mathrm{CC}<\mathrm{PF}}$ \\
\hline $\mathrm{B}^{\#}$ & $\mathrm{NA}$ \\
\hline $\mathrm{Ca}$ & $\underline{\mathrm{AR}<\mathrm{CC}}$ \\
\hline $\mathrm{Cr}$ & $\underline{\mathrm{AR}<\mathrm{CC}<\mathrm{PF}}$ \\
\hline $\mathrm{Cu}$ & $\underline{\mathrm{CC}<\mathrm{AR}<\mathrm{PF}}$ \\
\hline $\mathrm{Fe}$ & $\underline{\mathrm{PF}<\mathrm{AR}<\mathrm{CC}}$ \\
\hline $\mathrm{K}$ & $\mathrm{AR}<\mathrm{PF}$ \\
\hline $\mathrm{Li}$ & $\underline{\mathrm{PF}<\mathrm{AR}<\mathrm{CC}}$ \\
\hline $\mathrm{Mg}$ & $\underline{\mathrm{PF}<\mathrm{AR}<\mathrm{CC}}$ \\
\hline $\mathrm{Mn}$ & $\underline{\mathrm{AR}<\mathrm{PF}<\mathrm{CC}}$ \\
\hline $\mathrm{Na}$ & $\underline{\mathrm{AR}<\mathrm{CC}}$ \\
\hline $\mathrm{Ni}$ & $\underline{\mathrm{PF}<\mathrm{AR}<\mathrm{CC}}$ \\
\hline $\mathrm{Si}$ & $\mathrm{AR}<\mathrm{PF}$ \\
\hline $\mathrm{Th}$ & $\mathrm{CC}<\underline{\mathrm{PF}<\mathrm{AR}}$ \\
\hline $\mathrm{Ti}$ & $\mathrm{CC}<\underline{\mathrm{PF}<\mathrm{AR}}$ \\
\hline $\mathrm{U}$ & $\underline{\mathrm{PF}<\mathrm{AR}<\mathrm{CC}}$ \\
\hline $\mathrm{Zr}$ & $\mathrm{AR}<\mathrm{CC}$ \\
\hline
\end{tabular}

${ }^{\#}$ Below ICP-AES detection levels, less than values reported.

Observations and results from the SRAT Product digestions include the following:

- Brown/red solids and white solids remained in the solutions generated from the CC digestion after all acid addition steps and dilutions were performed. The brown/red colored solids eventually dissolved.

- A statistically larger average Al concentration is seen in the PF digestions compared to the $\mathrm{AR}$ and $\mathrm{CC}$ methods with an $\sim 2 \%$ and an $\sim 7 \%$ relative difference in the means, respectively.

- There is not a statistical difference in the means for Th between the AR and PF digestions but a statistical difference in the means is noted comparing the $\mathrm{CC}$ digestions to the AR and PF means with an $\sim 26 \%$ and an $\sim 18 \%$ relative difference in the means, respectively.

- A statistical difference of means between the three digestion methods is noted for the minor elements $\mathrm{Cu}, \mathrm{K}$, Ti and $\mathrm{Zr}$.

- There is not a statistical difference in the means for $\mathrm{Cr}, \mathrm{Fe}, \mathrm{Li}, \mathrm{Mg}, \mathrm{Mn}, \mathrm{Ni}$, or $\mathrm{U}$, nor is there a statistical difference in the mean $\mathrm{Na}$ concentration from the $\mathrm{AR}$ and $\mathrm{CC}$ digestions. 
The ARG digestions results are as follows. For the AR digestions, the mean $\mathrm{B}$, (slightly low) $\mathrm{Cu}$, and $\mathrm{Ti}$ results differed by more than $10 \%$ from the known concentration in the ARG-1 standard. Si and $\mathrm{Zr}$ are not considered because the mean results from of these elements are expected to be greater than $10 \%$ different. For the PF digestions, $\mathrm{B}, \mathrm{Ca}$ and $\mathrm{Cr}$ means were greater than $10 \%$ different from than the known concentrations in ARG-1. Ca is a contaminant in the PF reagents. For the CC digestions, the measured $\mathrm{Cu}$ concentration differed by more than $10 \%$ from the known concentration, most likely because the concentration in the solutions is very near the ICP-AES detection limit which is reflected by the high \%RSD reported with the measurement. 
Table 3-5. Elemental concentrations of ARG standard from ICP-AES analysis of Aqua Regia, and Sodium Peroxide/Hydroxide Fusion digestions performed concurrently with SB7b SRAT Receipt Sample. Values are presented on a weight percent $(\mathrm{Wt} \%)$ total solids basis.

\begin{tabular}{|c|c|c|c|c|}
\hline \multicolumn{5}{|c|}{ Aqua Regia } \\
\hline Element & $\begin{array}{c}\text { Average } \\
\text { Wt } \%\end{array}$ & $\begin{array}{c}\text { \%RSD - only one } \\
\text { Standard } \\
\text { Analyzed } \\
\end{array}$ & Standard Value & $\begin{array}{c}\text { \%Difference } \\
\text { (Measured vs } \\
\text { Standard Value) }\end{array}$ \\
\hline $\mathrm{Al}$ & $2.35 \mathrm{E}+00$ & NA & $2.50 \mathrm{E}+00$ & -6.0 \\
\hline $\mathrm{B}$ & $2.43 \mathrm{E}+00$ & NA & $2.69 \mathrm{E}+00$ & -9.7 \\
\hline $\mathrm{Ca}$ & $9.86 \mathrm{E}-01$ & NA & $1.02 \mathrm{E}+00$ & -3.3 \\
\hline $\mathrm{Cr}$ & $6.74 \mathrm{E}-02$ & NA & $6.40 \mathrm{E}-02$ & 5.3 \\
\hline $\mathrm{Cu}$ & $5.44 \mathrm{E}-03$ & NA & $3.00 \mathrm{E}-03$ & 81.3 \\
\hline $\mathrm{Fe}$ & $9.39 \mathrm{E}+00$ & NA & $9.79 \mathrm{E}+00$ & -4.1 \\
\hline $\mathrm{K}$ & $2.26 \mathrm{E}+00$ & NA & $2.26 \mathrm{E}+00$ & 0.0 \\
\hline $\mathrm{Li}$ & $1.40 \mathrm{E}+00$ & NA & $1.49 \mathrm{E}+00$ & -6.0 \\
\hline $\mathrm{Mg}$ & $5.17 \mathrm{E}-01$ & NA & $5.20 \mathrm{E}-01$ & -0.6 \\
\hline $\mathrm{Mn}$ & $1.47 \mathrm{E}+00$ & NA & $1.46 \mathrm{E}+00$ & 0.7 \\
\hline $\mathrm{Na}$ & $8.06 \mathrm{E}+00$ & NA & $8.52 \mathrm{E}+00$ & -5.4 \\
\hline $\mathrm{Ni}$ & $8.00 \mathrm{E}-01$ & NA & $8.27 \mathrm{E}-01$ & -3.3 \\
\hline $\mathrm{Si}$ & 9.99E-01 & NA & $2.24 \mathrm{E}+01$ & -95.5 \\
\hline $\mathrm{Ti}$ & $6.17 \mathrm{E}-01$ & NA & $6.90 \mathrm{E}-01$ & -10.6 \\
\hline $\mathrm{Zr}$ & $2.57 \mathrm{E}-02$ & NA & $9.60 \mathrm{E}-02$ & -73.2 \\
\hline \multicolumn{5}{|c|}{$\begin{array}{l}\text { Sodium Peroxide/Hydroxide Fusion } \\
\end{array}$} \\
\hline Element & $\begin{array}{c}\text { Average } \\
\text { Wt } \%\end{array}$ & $\begin{array}{c}\text { \%RSD - only one } \\
\text { Standard } \\
\text { Analyzed } \\
\end{array}$ & Standard Value & $\begin{array}{c}\text { \%Difference } \\
\text { (Measured } v s \\
\text { Standard Value) } \\
\end{array}$ \\
\hline $\mathrm{Al}$ & $2.59 \mathrm{E}+00$ & NA & $2.50 \mathrm{E}+00$ & 3.6 \\
\hline $\mathrm{B}$ & $2.52 \mathrm{E}+00$ & NA & $2.69 \mathrm{E}+00$ & -6.3 \\
\hline $\mathrm{Ca}$ & $1.20 \mathrm{E}+00$ & NA & $1.02 \mathrm{E}+00$ & 17.6 \\
\hline $\mathrm{Cr}$ & $7.09 \mathrm{E}-02$ & NA & $6.40 \mathrm{E}-02$ & 10.8 \\
\hline $\mathrm{Cu}$ & $<5.04 \mathrm{E}-03$ & NA & $3.00 \mathrm{E}-03$ & NA \\
\hline $\mathrm{Fe}$ & $9.97 \mathrm{E}+00$ & NA & $9.79 \mathrm{E}+00$ & 1.8 \\
\hline $\mathrm{K}$ & $2.32 \mathrm{E}+00$ & NA & $2.26 \mathrm{E}+00$ & 2.7 \\
\hline $\mathrm{Li}$ & $1.50 \mathrm{E}+00$ & NA & $1.49 \mathrm{E}+00$ & 0.7 \\
\hline $\mathrm{Mg}$ & $5.33 \mathrm{E}-01$ & NA & $5.20 \mathrm{E}-01$ & 2.5 \\
\hline $\mathrm{Mn}$ & $1.48 \mathrm{E}+00$ & NA & $1.46 \mathrm{E}+00$ & 1.4 \\
\hline $\mathrm{Na}$ & NA & NA & $8.52 \mathrm{E}+00$ & NA \\
\hline $\mathrm{Ni}$ & $8.54 \mathrm{E}-01$ & NA & $8.27 \mathrm{E}-01$ & 3.3 \\
\hline $\mathrm{Si}$ & $2.24 \mathrm{E}+01$ & NA & $2.24 \mathrm{E}+01$ & 0.0 \\
\hline $\mathrm{Ti}$ & $7.10 \mathrm{E}-01$ & NA & $6.90 \mathrm{E}-01$ & 2.9 \\
\hline $\mathrm{Zr}$ & NA & NA & $9.60 \mathrm{E}-02$ & NA \\
\hline
\end{tabular}

$\mathrm{NA}=$ Not applicable. $<\mathrm{MDL}=$ less than minimum detection limit. 
SRNL-STI-2011-00475, REVISION 0

Table 3-6. E concentrations of ARG standard from ICP-AES analysis DWPF Cold Chem method digestions performed concurrently with SB7b SRAT Receipt Sample. Values are presented on a weight percent (Wt\%) total solids basis.

\begin{tabular}{|c|c|c|c|c|}
\hline \multicolumn{2}{|c|}{ Average } & \%RSD & Known Value & $\begin{array}{c}\text { \%Difference } \\
\text { Measured vs } \\
\text { Known Value) }\end{array}$ \\
\hline $\mathrm{Al}$ & & & & 3.2 \\
\hline $\mathrm{B}$ & $2.58 \mathrm{E}+00$ & $2.2 \mathrm{E}+00$ & $2.50 \mathrm{E}+00$ & NA \\
\hline $\mathrm{Ca}$ & $\mathrm{NA}$ & $\mathrm{NA}$ & $2.69 \mathrm{E}+00$ & 10.8 \\
\hline $\mathrm{Cr}$ & $1.13 \mathrm{E}+00$ & $1.3 \mathrm{E}+00$ & $1.02 \mathrm{E}+00$ & 13.8 \\
\hline $\mathrm{Cu}$ & $7.29 \mathrm{E}-02$ & $1.8 \mathrm{E}+00$ & $6.40 \mathrm{E}-02$ & 25.7 \\
\hline $\mathrm{Fe}$ & $3.77 \mathrm{E}-03$ & $2.2 \mathrm{E}+01$ & $3.00 \mathrm{E}-03$ & 7.3 \\
\hline $\mathrm{K}$ & $1.05 \mathrm{E}+01$ & $1.3 \mathrm{E}+00$ & $9.79 \mathrm{E}+00$ & 7.4 \\
\hline $\mathrm{Li}$ & $2.33 \mathrm{E}+00$ & $3.0 \mathrm{E}-01$ & $2.26 \mathrm{E}+00$ & 6.9 \\
\hline $\mathrm{Mg}$ & $1.60 \mathrm{E}+00$ & $1.8 \mathrm{E}+00$ & $1.49 \mathrm{E}+00$ & 5.8 \\
\hline $\mathrm{Mn}$ & $5.56 \mathrm{E}-01$ & $1.0 \mathrm{E}+00$ & $5.20 \mathrm{E}-01$ & 3.9 \\
\hline $\mathrm{Na}$ & $1.55 \mathrm{E}+00$ & $1.4 \mathrm{E}+00$ & $1.46 \mathrm{E}+00$ & 4.4 \\
\hline $\mathrm{Ni}$ & $8.85 \mathrm{E}+00$ & $1.1 \mathrm{E}+00$ & $8.52 \mathrm{E}+00$ & $\mathrm{NA}$ \\
\hline $\mathrm{Si}$ & $8.64 \mathrm{E}-01$ & $1.2 \mathrm{E}+00$ & $8.27 \mathrm{E}-01$ & 3.8 \\
\hline $\mathrm{Zr}$ & $\mathrm{NA}$ & $\mathrm{NA}$ & $2.24 \mathrm{E}+01$ & 7.8 \\
\hline
\end{tabular}

$*$ All averages are based upon three replicate dissolutions and ICP-AES determinations NA $=$ Not applicable. 
Table 3-7. Elemental concentrations of ARG standard from ICP-AES analysis of Aqua Regia, and Sodium Peroxide/Hydroxide Fusion digestions performed concurrently with SB7b SRAT Product sample. Values are presented on a weight percent $(\mathrm{Wt} \%)$ total solids basis.

\begin{tabular}{|c|c|c|c|c|}
\hline \multicolumn{5}{|c|}{ Aqua Regia* } \\
\hline Element & Average & $\%$ RSD & Standard Value & $\begin{array}{c}\text { \%Difference } \\
\text { (Measured vs } \\
\text { Standard Value) }\end{array}$ \\
\hline $\mathrm{Al}$ & $2.30 \mathrm{E}+00$ & $1.2 \mathrm{E}+00$ & $2.50 \mathrm{E}+00$ & -8.0 \\
\hline $\mathrm{B}$ & $2.41 \mathrm{E}+00$ & $2.9 \mathrm{E}-01$ & $2.69 \mathrm{E}+00$ & -10.6 \\
\hline $\mathrm{Ca}$ & $1.04 \mathrm{E}+00$ & $6.8 \mathrm{E}-01$ & $1.02 \mathrm{E}+00$ & 1.5 \\
\hline $\mathrm{Cr}$ & $6.68 \mathrm{E}-02$ & $7.4 \mathrm{E}+00$ & $6.40 \mathrm{E}-02$ & 4.4 \\
\hline $\mathrm{Cu}$ & $2.34 \mathrm{E}-03$ & $7.0 \mathrm{E}+00$ & $3.00 \mathrm{E}-03$ & -22.2 \\
\hline $\mathrm{Fe}$ & $9.78 \mathrm{E}+00$ & $1.2 \mathrm{E}+00$ & $9.79 \mathrm{E}+00$ & -0.1 \\
\hline $\mathrm{K}$ & $2.09 \mathrm{E}+00$ & $1.7 \mathrm{E}+00$ & $2.26 \mathrm{E}+00$ & -7.7 \\
\hline $\mathrm{Li}$ & $1.50 \mathrm{E}+00$ & $9.4 \mathrm{E}-01$ & $1.49 \mathrm{E}+00$ & 0.7 \\
\hline $\mathrm{Mg}$ & $5.31 \mathrm{E}-01$ & $7.5 \mathrm{E}+00$ & $5.20 \mathrm{E}-01$ & 2.1 \\
\hline $\mathrm{Mn}$ & $1.42 \mathrm{E}+00$ & $1.0 \mathrm{E}+00$ & $1.46 \mathrm{E}+00$ & -2.7 \\
\hline $\mathrm{Na}$ & $8.48 \mathrm{E}+00$ & $2.5 \mathrm{E}-01$ & $8.52 \mathrm{E}+00$ & -0.5 \\
\hline $\mathrm{Ni}$ & $8.26 \mathrm{E}-01$ & $1.7 \mathrm{E}+00$ & $8.27 \mathrm{E}-01$ & -0.1 \\
\hline $\mathrm{Si}$ & $3.39 \mathrm{E}-01$ & $1.4 \mathrm{E}+01$ & $2.24 \mathrm{E}+01$ & -98.5 \\
\hline $\mathrm{Ti}$ & $6.05 \mathrm{E}-01$ & $7.2 \mathrm{E}+00$ & $6.90 \mathrm{E}-01$ & -12.3 \\
\hline $\mathrm{Zr}$ & $5.38 \mathrm{E}-02$ & $1.7 \mathrm{E}+01$ & $9.60 \mathrm{E}-02$ & -44.0 \\
\hline \multicolumn{5}{|c|}{ Sodium Peroxide/Hydroxide Fusion* } \\
\hline Element & Average & \%RSD & Known Value & $\begin{array}{c}\text { \%Difference } \\
\text { (Measured vs } \\
\text { Known Value) }\end{array}$ \\
\hline $\mathrm{Al}$ & $2.58 \mathrm{E}+00$ & $2.5 \mathrm{E}+00$ & $2.50 \mathrm{E}+00$ & 3.0 \\
\hline $\mathrm{B}$ & $2.50 \mathrm{E}+00$ & $2.0 \mathrm{E}+00$ & $2.69 \mathrm{E}+00$ & -8.6 \\
\hline $\mathrm{Ca}$ & $1.18 \mathrm{E}+00$ & $1.2 \mathrm{E}+00$ & $1.02 \mathrm{E}+00$ & 15.7 \\
\hline $\mathrm{Cr}$ & 7.29E-02 & $3.0 \mathrm{E}+00$ & $6.40 \mathrm{E}-02$ & 13.8 \\
\hline $\mathrm{Cu}$ & $<4.92 \mathrm{E}-03$ & NA & $3.00 \mathrm{E}-03$ & NA \\
\hline $\mathrm{Fe}$ & $1.02 \mathrm{E}+01$ & $2.1 \mathrm{E}+00$ & $9.79 \mathrm{E}+00$ & 3.7 \\
\hline $\mathrm{K}$ & $2.30 \mathrm{E}+00$ & $9.2 \mathrm{E}-01$ & $2.26 \mathrm{E}+00$ & 1.5 \\
\hline $\mathrm{Li}$ & $1.51 \mathrm{E}+00$ & $2.8 \mathrm{E}+00$ & $1.49 \mathrm{E}+00$ & 1.3 \\
\hline $\mathrm{Mg}$ & $5.31 \mathrm{E}-01$ & $9.3 \mathrm{E}-01$ & $5.20 \mathrm{E}-01$ & 2.0 \\
\hline $\mathrm{Mn}$ & $1.51 \mathrm{E}+00$ & $1.4 \mathrm{E}+00$ & $1.46 \mathrm{E}+00$ & 3.1 \\
\hline $\mathrm{Na}$ & NA & NA & $8.52 \mathrm{E}+00$ & NA \\
\hline $\mathrm{Ni}$ & $8.36 \mathrm{E}-01$ & $8.5 \mathrm{E}-01$ & $8.27 \mathrm{E}-01$ & 1.1 \\
\hline $\mathrm{Si}$ & $2.36 \mathrm{E}+01$ & $1.8 \mathrm{E}+00$ & $2.24 \mathrm{E}+01$ & 5.4 \\
\hline $\mathrm{Ti}$ & $7.07 \mathrm{E}-01$ & $1.8 \mathrm{E}+00$ & $6.90 \mathrm{E}-01$ & 2.5 \\
\hline $\mathrm{Zr}$ & NA & NA & $9.60 \mathrm{E}-02$ & $\mathrm{NA}$ \\
\hline
\end{tabular}

*All averages are based upon two replicate dissolutions and ICP-AES determinations. NA = Not applicable. $<\mathrm{MDL}=$ less than minimum detection limit. 
Table 3-8. Continuation of elemental concentrations of ARG standard from ICP-AES analysis of Aqua Regia, DWPF Cold Chem method and Sodium Peroxide/Hydroxide Fusion digestions performed concurrently with SB7b SRAT Product sample. Values are presented on a weight percent $(\mathrm{Wt} \%)$ total solids basis.

\begin{tabular}{|c|c|c|c|c|}
\hline \multicolumn{5}{|c|}{ DWPF Cold Chem Method* } \\
\hline Element & Average & \%RSD & Known Value & $\begin{array}{c}\text { \%Difference } \\
\text { (Measured vs } \\
\text { Known Value) }\end{array}$ \\
\hline $\mathrm{Al}$ & $2.45 \mathrm{E}+00$ & $7.6 \mathrm{E}+00$ & $2.50 \mathrm{E}+00$ & -2.0 \\
\hline $\mathrm{B}$ & NA & NA & $2.69 \mathrm{E}+00$ & NA \\
\hline $\mathrm{Ca}$ & $1.07 \mathrm{E}+00$ & $1.4 \mathrm{E}+01$ & $1.02 \mathrm{E}+00$ & 4.7 \\
\hline $\mathrm{Cr}$ & $6.92 \mathrm{E}-02$ & $4.6 \mathrm{E}+00$ & $6.40 \mathrm{E}-02$ & 8.1 \\
\hline $\mathrm{Cu}$ & $3.93 \mathrm{E}-03$ & $1.6 \mathrm{E}+01$ & $3.00 \mathrm{E}-03$ & 31.0 \\
\hline $\mathrm{Fe}$ & $1.03 \mathrm{E}+01$ & $6.1 \mathrm{E}+00$ & $9.79 \mathrm{E}+00$ & 5.1 \\
\hline $\mathrm{K}$ & $2.29 \mathrm{E}+00$ & $5.7 \mathrm{E}+00$ & $2.26 \mathrm{E}+00$ & 1.3 \\
\hline $\mathrm{Li}$ & $1.54 \mathrm{E}+00$ & $7.1 \mathrm{E}+00$ & $1.49 \mathrm{E}+00$ & 3.6 \\
\hline $\mathrm{Mg}$ & $5.40 \mathrm{E}-01$ & $1.0 \mathrm{E}+01$ & $5.20 \mathrm{E}-01$ & 3.8 \\
\hline $\mathrm{Mn}$ & $1.52 \mathrm{E}+00$ & $6.1 \mathrm{E}+00$ & $1.46 \mathrm{E}+00$ & 3.9 \\
\hline $\mathrm{Na}$ & $8.98 \mathrm{E}+00$ & $6.8 \mathrm{E}+00$ & $8.52 \mathrm{E}+00$ & 5.4 \\
\hline $\mathrm{Ni}$ & $8.99 \mathrm{E}-01$ & $5.9 \mathrm{E}+00$ & $8.27 \mathrm{E}-01$ & 8.7 \\
\hline $\mathrm{Si}$ & NA & NA & $2.24 \mathrm{E}+01$ & NA \\
\hline $\mathrm{Ti}$ & $7.03 \mathrm{E}-01$ & $6.2 \mathrm{E}+00$ & $6.90 \mathrm{E}-01$ & 1.8 \\
\hline $\mathrm{Zr}$ & $1.01 \mathrm{E}-01$ & $6.1 \mathrm{E}+00$ & $9.60 \mathrm{E}-02$ & 5.3 \\
\hline
\end{tabular}

*All averages are based upon three replicate dissolutions and ICP-AES determinations NA $=$ Not applicable. $<\mathrm{MDL}=$ less than minimum detection limit.

Good recoveries were observed for most elements of significant weight percent in the ARG standards. There are a few anomalies but based upon the \%RSDs some of these elements were near the ICP-AES detection limit. Upon review of the SRAT Receipt, SRAT Product and ARG data it is evident that not all of the digestion issues seen with the radioactive sample are mirrored with the ARG standard. For instance, the $\mathrm{Al}$ in the ARG appears to dissolve well in each digestion method as well as Fe. The SRAT Receipt and SRAT Product have $\sim 4 \mathrm{wt} \%$ more Fe than the ARG standard. The one and one-half hour time frame allotted for the digestion may not be sufficient for dissolving all of the Fe and $\mathrm{Mn}$ in the initial dilution of the samples. SB7b also contains some HM waste and some the different phases of aluminum species present in the sludge slurry (boehmite and gibbsite among others) have less solubility in acid matrices. 
This page intentionally left blank 


\subsection{CONCLUSIONS}

The results from using the DWPF CC method to digest SB7b sludge slurry appear, in most cases, to be equivalent to the $\mathrm{AR}$ and $\mathrm{PF}$ digestion methods. Visual observations indicate $\mathrm{Fe}$ and $\mathrm{Mn}$ may not be completely dissolving in the initial dilution of the DWPF CC sample before the final dilution is performed. However, ICP-AES analysis indicates the Fe and Mn mean concentration from all three digestions are not statistically different. The DWPF should consider comparing the Fe and $\mathrm{Mn}$ results obtained from PF digestion of the SRAT Product against the DWPF CC results and using the highest average.

Aluminum (Al) and Th do not dissolve completely or are precipitated as fluoride salts. It is recommended that these elements be determined from analysis of samples digested by the PF method. 
This page intentionally left blank 


\subsection{RECOMMENDATIONS}

Based on the results from performing three different digestion methods on SB7b sludge slurry, SRNL notes and recommends the following:

- The results from using the DWPF CC method performed to digest SB7b sludge slurry appear, in most cases, to be equivalent to the AR and PF digestion methods. However, Al, and Th should be analyzed by the peroxide fusion method for SB7b. Visual observations indicate Fe and Mn may not be completely dissolving in the initial dilution of the sample before the final dilution is performed. However, for this data set, very small relative differences between the digestion methods are noted and no statistical difference is observed between the digestion methods for $\mathrm{Fe}$ and Mn. Fe and Mn concentration should be measured from both a CC and PF digestion of SB7b sludge slurry and the highest concentration between the two digestions should be used. Although $\mathrm{K}$ is a minor element, large relative differences are noted in this report between the different digestions and the DWPF should also monitor the K concentration.

- The DWPF CC method was originally developed to be used for SME analyses. Given continuous visual observations of solids in the CC digestions both at SRNL and DWPF, potential issues with accurate $\mathrm{Al}$ measurements when processing $\mathrm{HM}$ waste, and difficulty measuring Th accurately due to the limited solubility of Th in HF matrices, SRNL recommends that the DWPF consider a different digestion scheme that relieves some of these issues.

- The DWPF CC results from this study indicate Al and Th do not completely dissolve or precipitate as fluoride salts. Visual observations also indicate Fe and Mn may not completely dissolve using the DWPF CC method. Therefore, DWPF should consider and monitor the impact of these elements on SB7b blending operations conducted at DWPF via comparison of SRAT and SME analyses. If a consistent difference in elemental concentrations is revealed, another type of digestion (i.e. sodium peroxide/hydroxide fusion) should be used to determine the concentration of the element in question. Particular emphasis should be placed on monitoring $\mathrm{Al}, \mathrm{Fe}, \mathrm{Mn}, \mathrm{K}$, and Th concentrations in SB7b. 
This page intentionally left blank 


\subsection{REFERENCES}

1. C.J. Coleman, “Alkali Fusion Dissolutions of Sludge and Glass for Elemental and Anion Analysis", ADS Procedure ADS-2502, Rev. 6.

2. C.J. Coleman, “Aqua Regia Dissolution of Sludge for Elemental Analysis”, ADS Procedure ADS-2226, Rev. 9.

3. JMP Statistical Discovery Software v 7.0.2; SAS Institute Inc., Cary, NC, 2008.

4. C.J. Coleman, F.M. Pennebaker, B.H. Burch and D.R. Click, "Evaluation of the DWPF Cold Chem Dissolution Method with DWPF Sludge Batch 3 Simulant", WSRC-TR-0200496, Rev. 0. See also D.R. Click, "Evaluation of the DWPF Cold Chem Dissolution Method with Tank 7 and Tank 51 Radioactive Sludges", WSRC-TR-2003-00580. D.R. Click, C.J. Coleman, K.E. Zeigler and T.B. Edwards, "Sludge Batch Four (4) Defense Waste Processing Facility (DWPF) Process Analytical Method Verification", WSRCSTI-2006-00025 Rev. 0. D. R. Click, T. B. Edwards, and M. A. Jones. "Verification of the Defense Waste Processing Facility's (DWPF) process digestion method for the Sludge Batch 6 qualification sample", WSRC-STI-2010-00259 Rev. 0. D.R. Click, T.B. Edwards, M.A. Jones, and B.J. Wiedenman, "Verification of the Defense Waste Processing Facility's (DWPF) Process Digestion Method for the Sludge Batch 7a Qualification Sample, SRNL-STI-2011-00158 Rev. 0. 
This page intentionally left blank 


\subsection{ACKNOWLEDGEMENTS}

The authors would like to acknowledge Monica Jenkins and Rita Sullivan. 
This page intentionally left blank 
SRNL-STI-2011-00475, REVISION 0

\subsection{APPENDIX A. SUPPORTING INFORMATION}


SRNL-STI-2011-00475, REVISION 0

\begin{tabular}{|c|c|c|c|c|c|c|c|c|}
\hline & Receipt & Receipt & Receipt & Statistical & Product & Product & Product & Statistical \\
\hline Element & $\begin{array}{c}\text { Aqua } \\
\text { Regia }\end{array}$ & $\begin{array}{c}\text { Cold } \\
\text { Chem }\end{array}$ & $\begin{array}{c}\text { Peroxide } \\
\text { Fusions }\end{array}$ & Comparisons & $\begin{array}{c}\text { Aqua } \\
\text { Regia }\end{array}$ & $\begin{array}{c}\text { Cold } \\
\text { Chem }\end{array}$ & $\begin{array}{c}\text { Peroxide } \\
\text { Fusions }\end{array}$ & Comparisons \\
\hline $\mathrm{Al}$ & 8.478 & 8.140 & 8.830 & $\underline{\mathrm{CC}<\mathrm{AR}<\mathrm{PF}}$ & 7.645 & 8.218 & 8.487 & $\underline{\mathrm{AR}<\mathrm{CC}<\mathrm{PF}}$ \\
\hline $\mathrm{B}$ & 0.008 & $\cdot$ & 0.081 & $\mathrm{AR}<\mathrm{PF}$ & 0.008 & $\cdot$ & 0.017 & $\mathrm{AR}<\mathrm{PF}$ \\
\hline $\mathrm{Ca}$ & 0.638 & 0.662 & 0.753 & $\underline{\mathrm{AR}<\mathrm{CC}<\mathrm{PF}}$ & 0.614 & 0.620 & 0.760 & $\underline{\mathrm{AR}<\mathrm{CC}<\mathrm{PF}}$ \\
\hline $\mathrm{Cr}$ & 0.043 & 0.044 & 0.060 & $\underline{\mathrm{AR}<\mathrm{CC}<\mathrm{PF}}$ & 0.041 & 0.045 & 0.046 & $\underline{\mathrm{AR}<\mathrm{CC}<\mathrm{PF}}$ \\
\hline $\mathrm{Cu}$ & 0.080 & 0.044 & 0.049 & $\underline{\mathrm{CC}<\mathrm{PF}<\mathrm{AR}}$ & 0.040 & 0.040 & 0.044 & $\underline{\mathrm{CC}<\mathrm{AR}<\mathrm{PF}}$ \\
\hline $\mathrm{Fe}$ & 14.225 & 14.475 & 14.300 & $\underline{\mathrm{AR}<\mathrm{PF}<\mathrm{CC}}$ & 13.740 & 13.750 & 13.644 & $\underline{\mathrm{PF}<\mathrm{AR}<\mathrm{CC}}$ \\
\hline $\mathrm{K}$ & 0.026 & 0.188 & 0.255 & $\mathrm{AR}<\mathrm{CC}<\mathrm{PF}$ & 0.055 & 0.128 & 0.289 & $\mathrm{AR}<\mathrm{CC}<\mathrm{PF}$ \\
\hline $\mathrm{Li}$ & 0.026 & 0.025 & 0.023 & $\underline{\mathrm{PF}<\mathrm{CC}<\mathrm{AR}}$ & 0.025 & 0.026 & 0.025 & $\underline{\mathrm{PF}<\mathrm{AR}<\mathrm{CC}}$ \\
\hline $\mathrm{Mg}$ & 0.285 & 0.296 & 0.277 & $\underline{\mathrm{PF}<\mathrm{AR}<\mathrm{CC}}$ & 0.278 & 0.293 & 0.274 & $\underline{\mathrm{PF}<\mathrm{AR}<\mathrm{CC}}$ \\
\hline $\mathrm{Mn}$ & 3.015 & 3.123 & 2.980 & $\underline{\mathrm{PF}<\mathrm{AR}<\mathrm{CC}}$ & 2.935 & 3.015 & 2.974 & $\underline{\mathrm{AR}<\mathrm{PF}<\mathrm{CC}}$ \\
\hline $\mathrm{Na}$ & 14.125 & 14.575 &. & $\underline{\mathrm{AR}<\mathrm{CC}}$ & 14.894 & 15.125 &. & $\underline{\mathrm{AR}<\mathrm{CC}}$ \\
\hline $\mathrm{Ni}$ & 2.935 & 2.975 & 2.953 & $\underline{\mathrm{AR}<\mathrm{PF}<\mathrm{CC}}$ & 2.815 & 2.823 & 2.757 & $\underline{\mathrm{PF}<\mathrm{AR}<\mathrm{CC}}$ \\
\hline $\mathrm{Si}$ & 0.472 &. & 1.057 & $\mathrm{AR}<\mathrm{PF}$ & 0.420 &. & 1.070 & $\mathrm{AR}<\mathrm{PF}$ \\
\hline $\mathrm{Th}$ & 1.036 & 0.761 & 0.956 & $\mathrm{CC}<\underline{\mathrm{PF}<\mathrm{AR}}$ & 1.063 & 0.727 & 0.940 & $\mathrm{CC}<\underline{\mathrm{PF}<\mathrm{AR}}$ \\
\hline $\mathrm{Ti}$ & 0.017 & 0.019 & 0.020 & $\mathrm{AR}<\underline{\mathrm{CC}<\mathrm{PF}}$ & 0.020 & 0.015 & 0.020 & $\mathrm{CC}<\underline{\mathrm{PF}<\mathrm{AR}}$ \\
\hline $\mathrm{U}$ & 4.773 & 4.980 & 4.453 & $\mathrm{PF}<\underline{\mathrm{AR}<\mathrm{CC}}$ & 4.480 & 4.510 & 4.260 & $\underline{\mathrm{PF}<\mathrm{AR}<\mathrm{CC}}$ \\
\hline $\mathrm{Zr}$ & 0.139 & 0.270 &. & $\mathrm{AR}<\mathrm{CC}$ & 0.150 & 0.254 &. & $\mathrm{AR}<\mathrm{CC}$ \\
\hline
\end{tabular}


SRNL-STI-2011-00475, REVISION 0

Variability Chart for Al

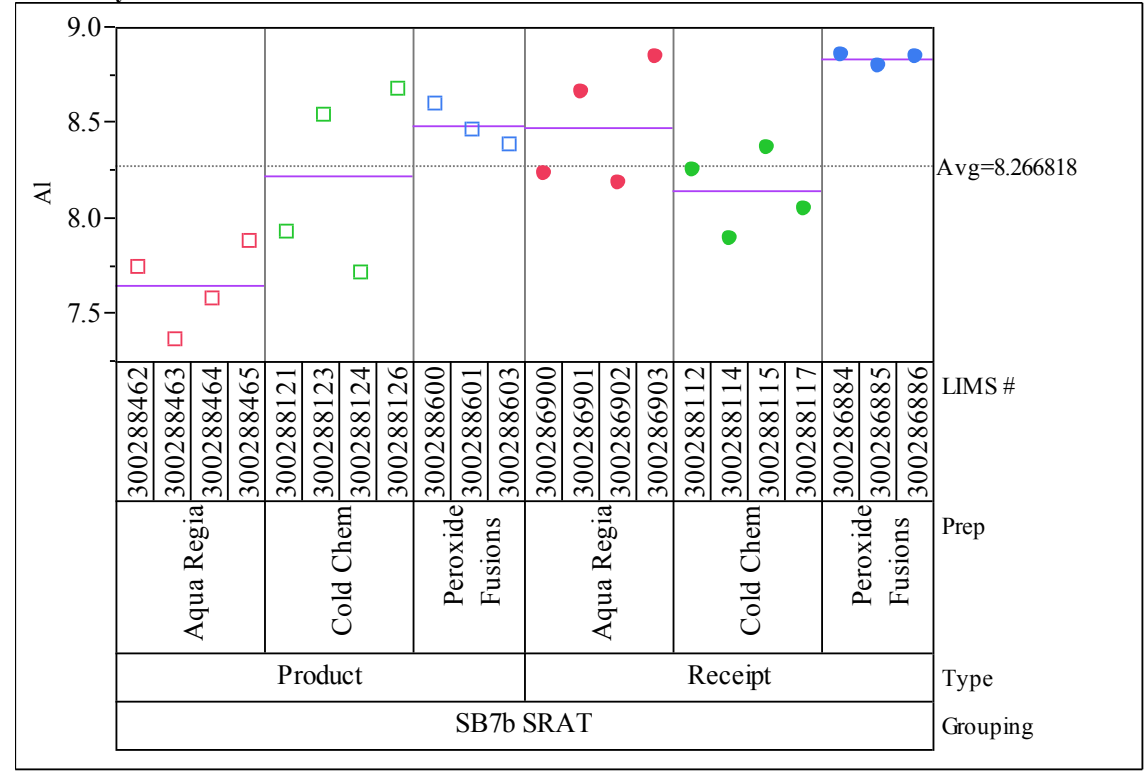

Variability Chart for B

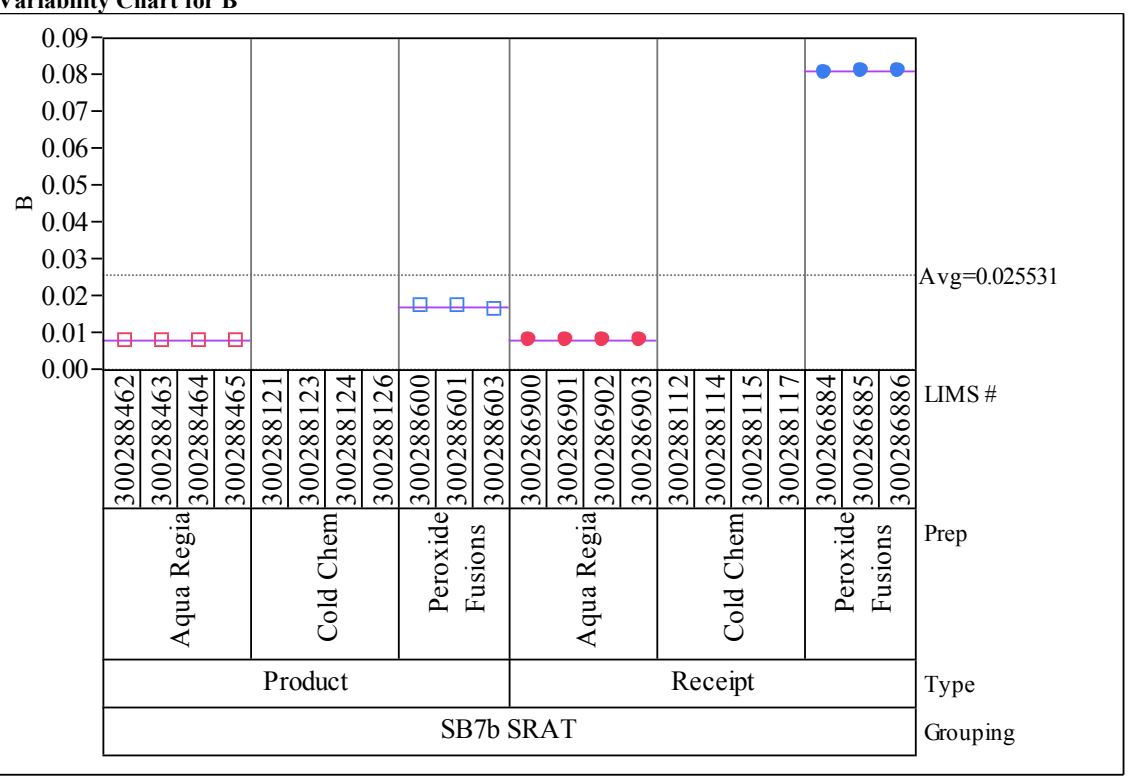

Variability Chart for Ca
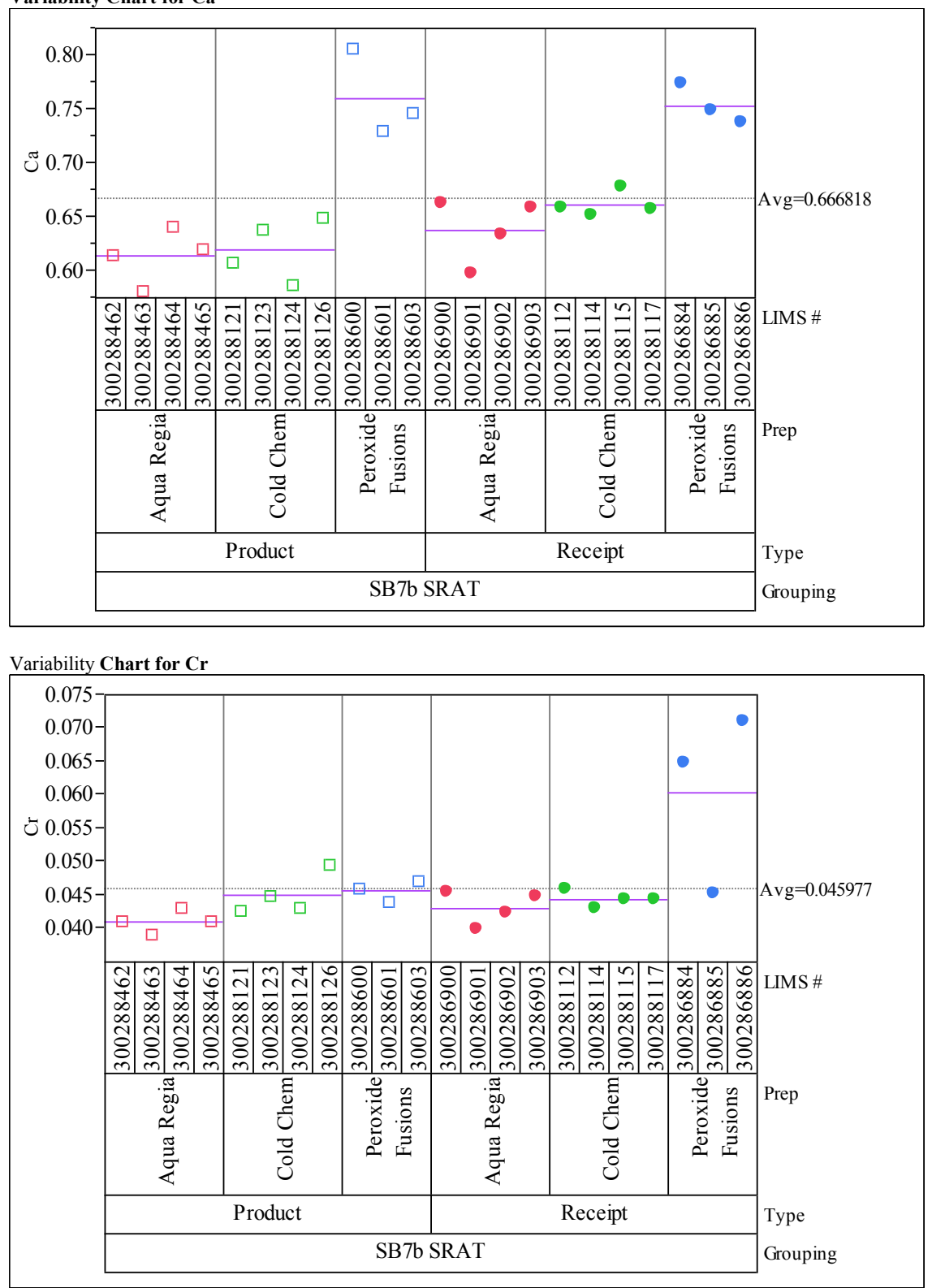
SRNL-STI-2011-00475, REVISION 0

Variability Chart for $\mathrm{Cu}$

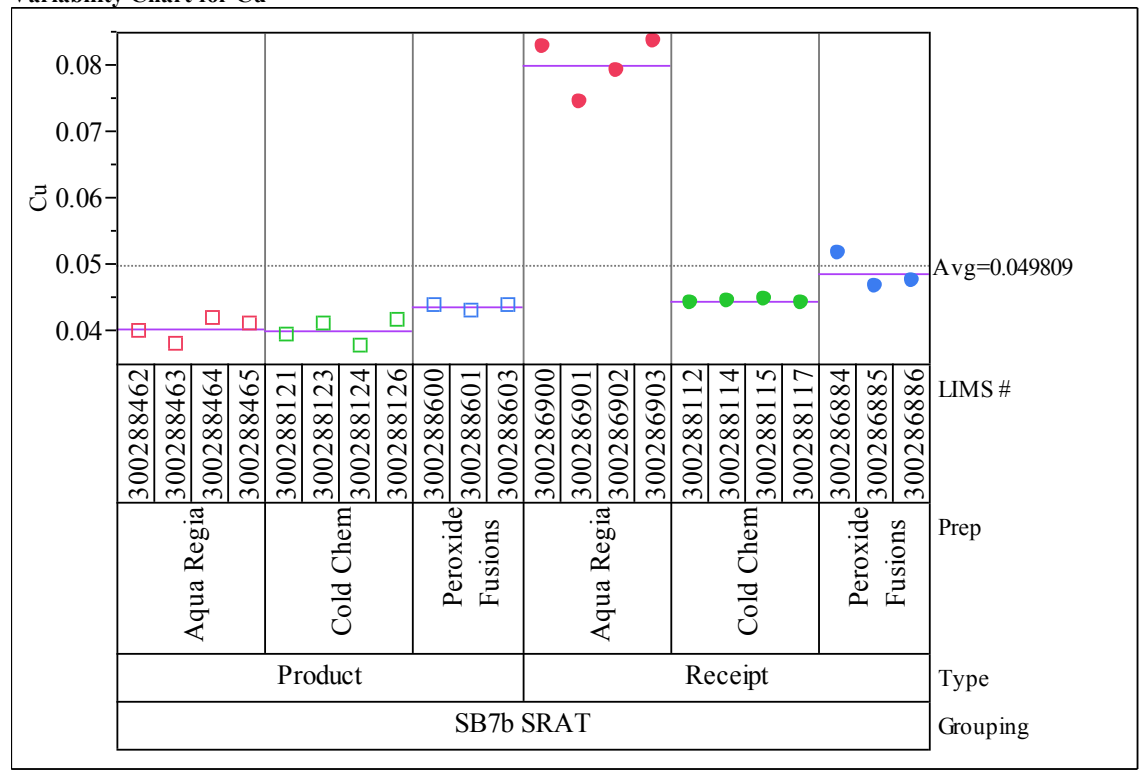

Variability Chart for $\mathrm{Fe}$

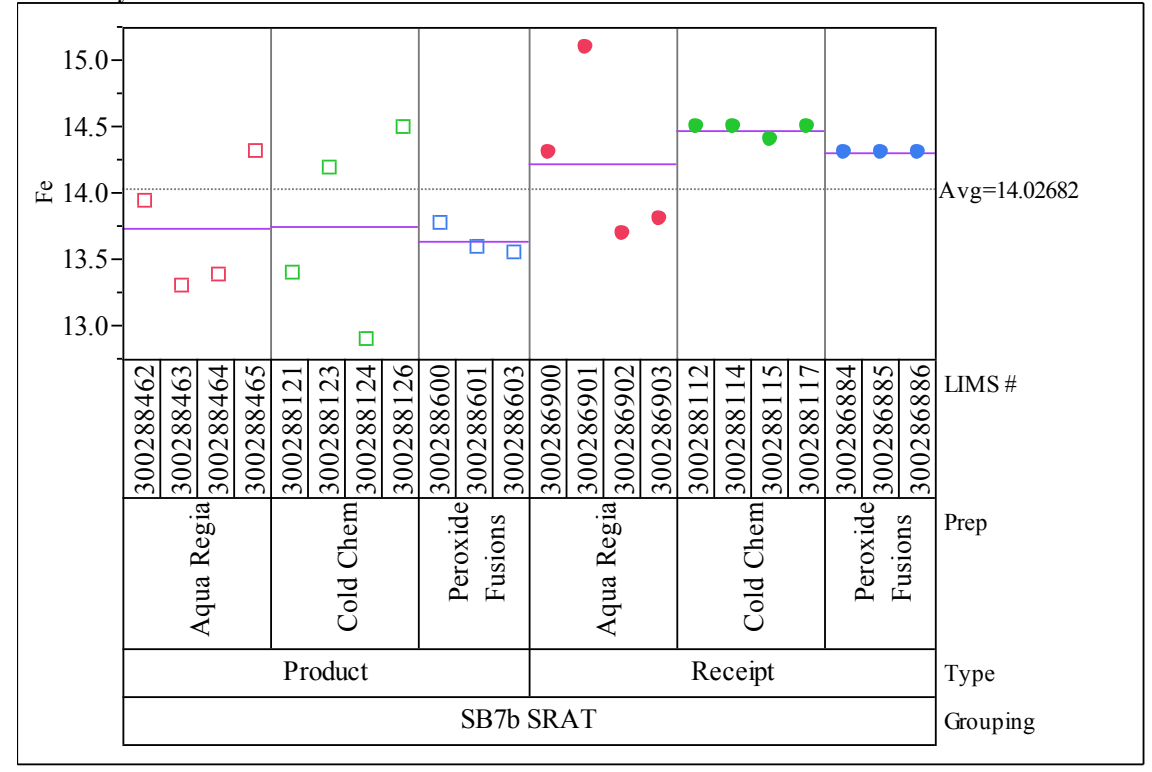

Variability Chart for $\mathrm{K}$

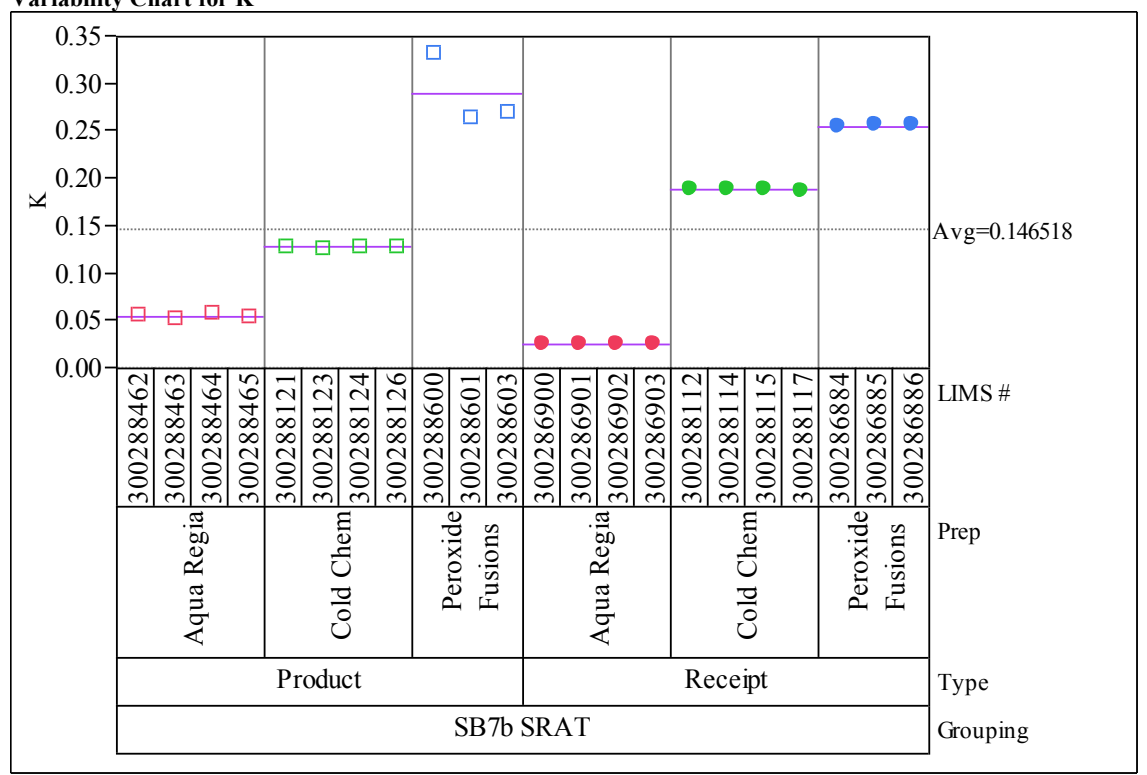

Variability Chart for Li

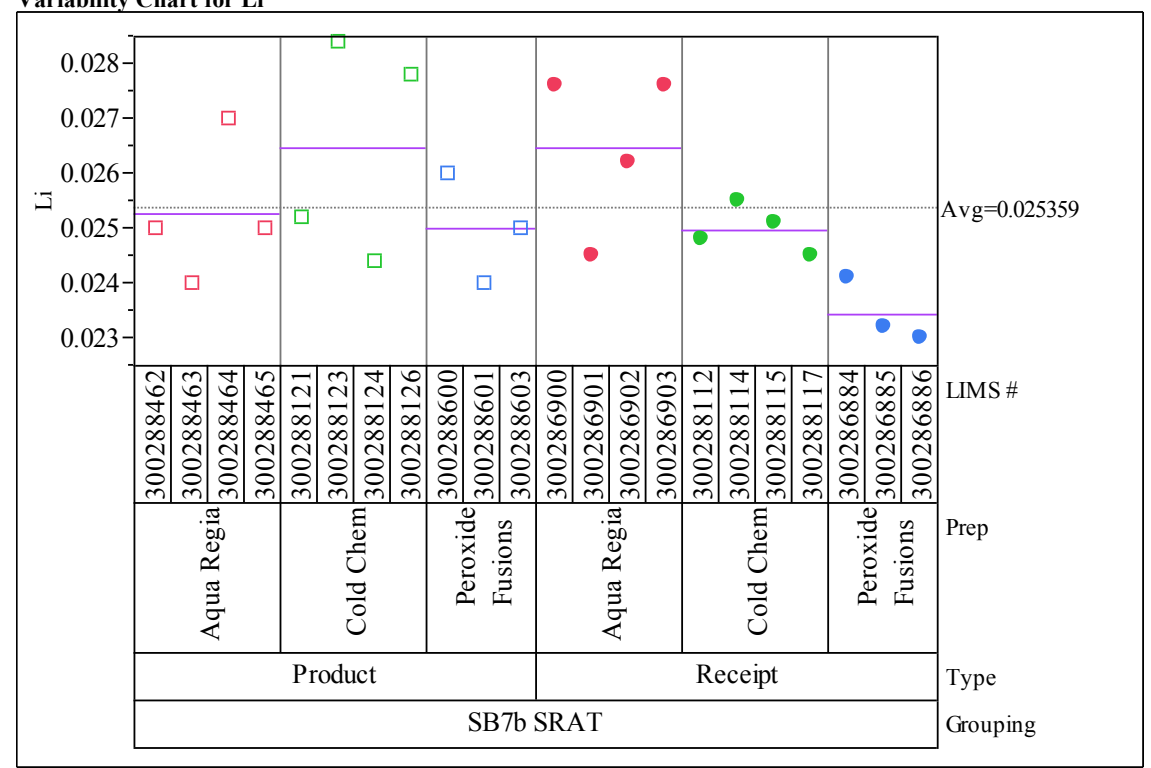


SRNL-STI-2011-00475, REVISION 0

Variability Chart for Mg
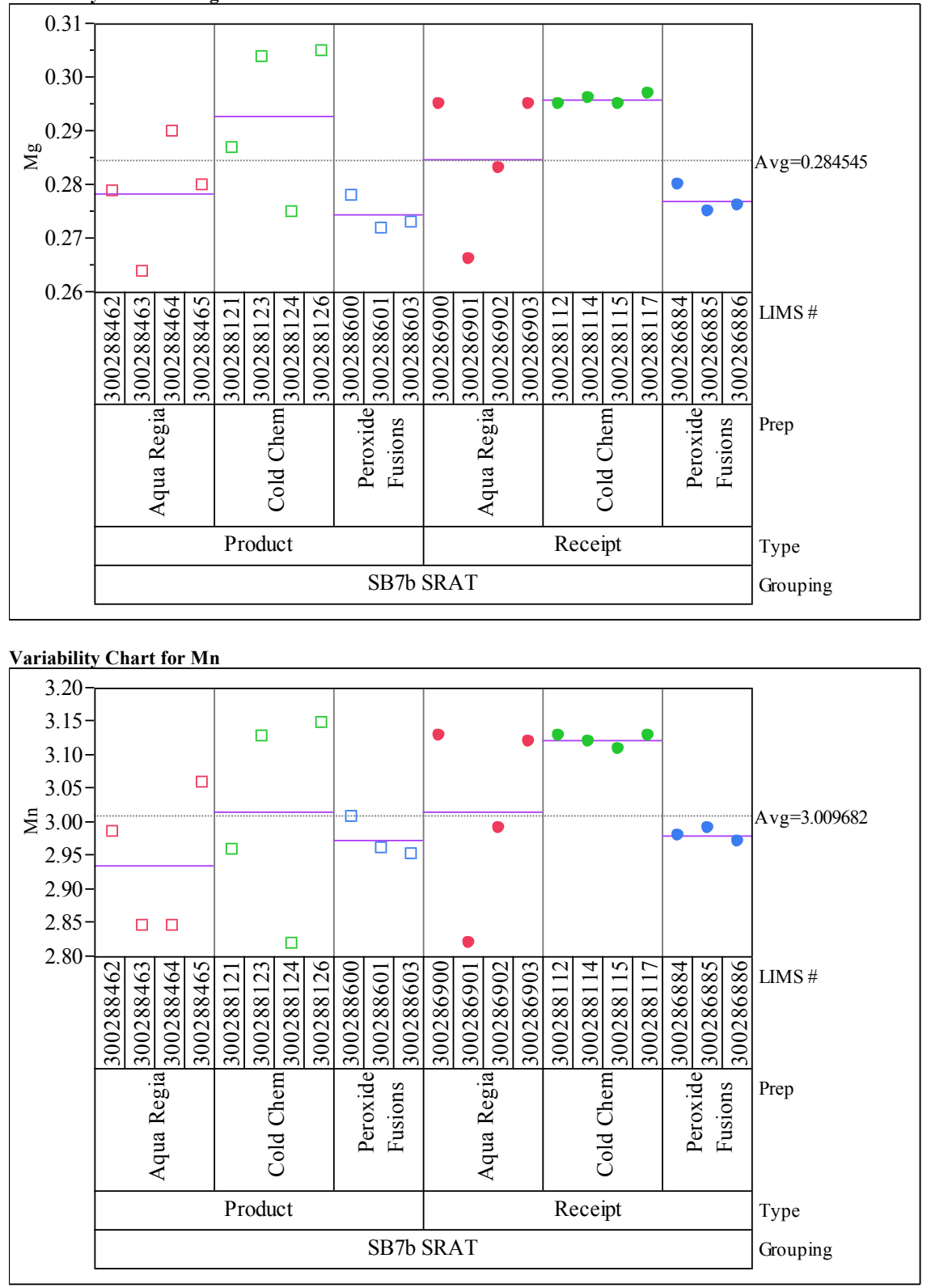

Variability Chart for Na
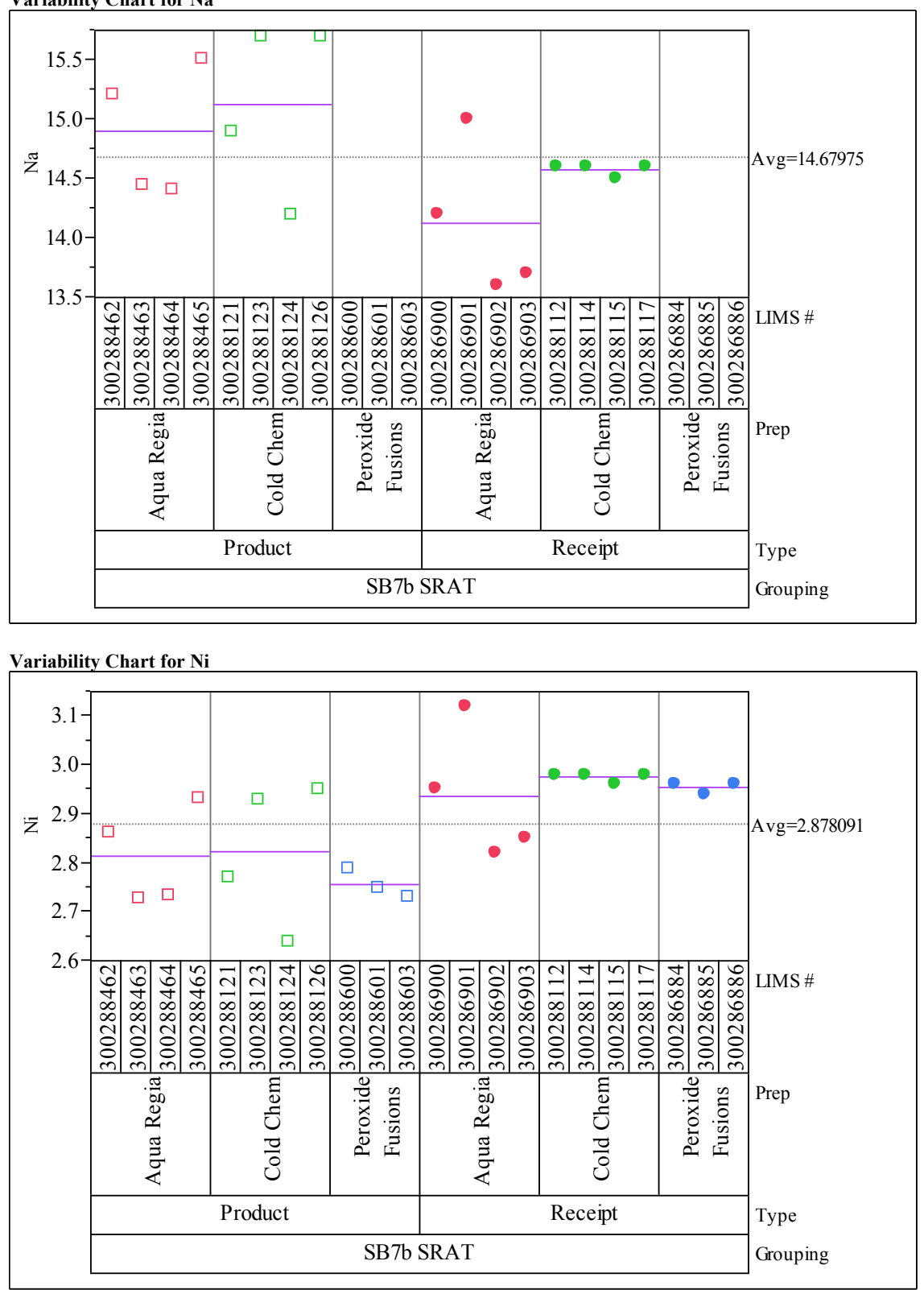
SRNL-STI-2011-00475, REVISION 0

Variability Chart for $\mathrm{Si}$

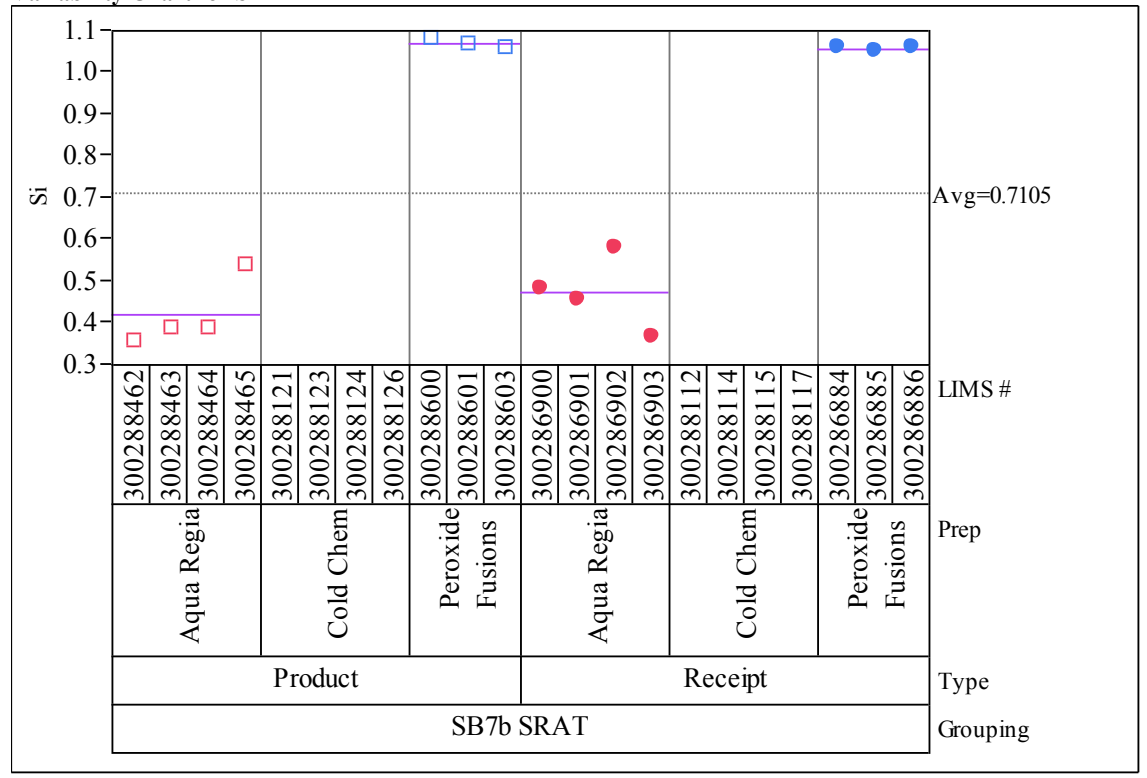

Variability Chart for Th

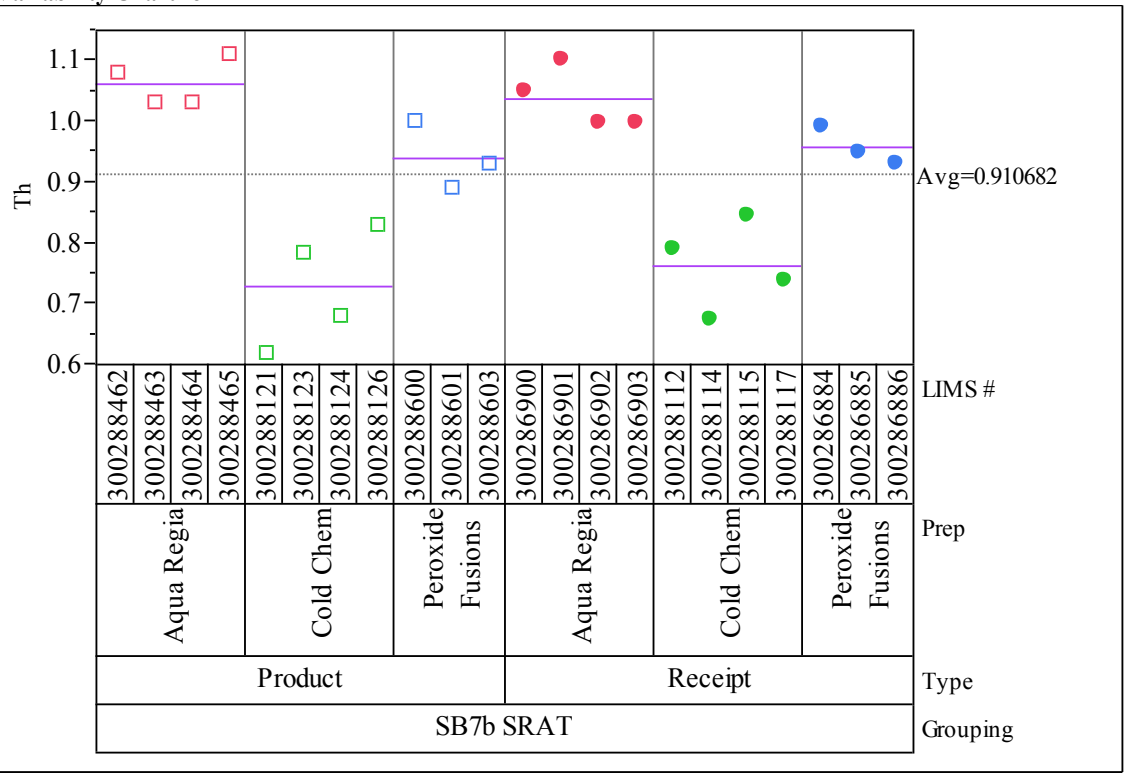

Variability Chart for Ti
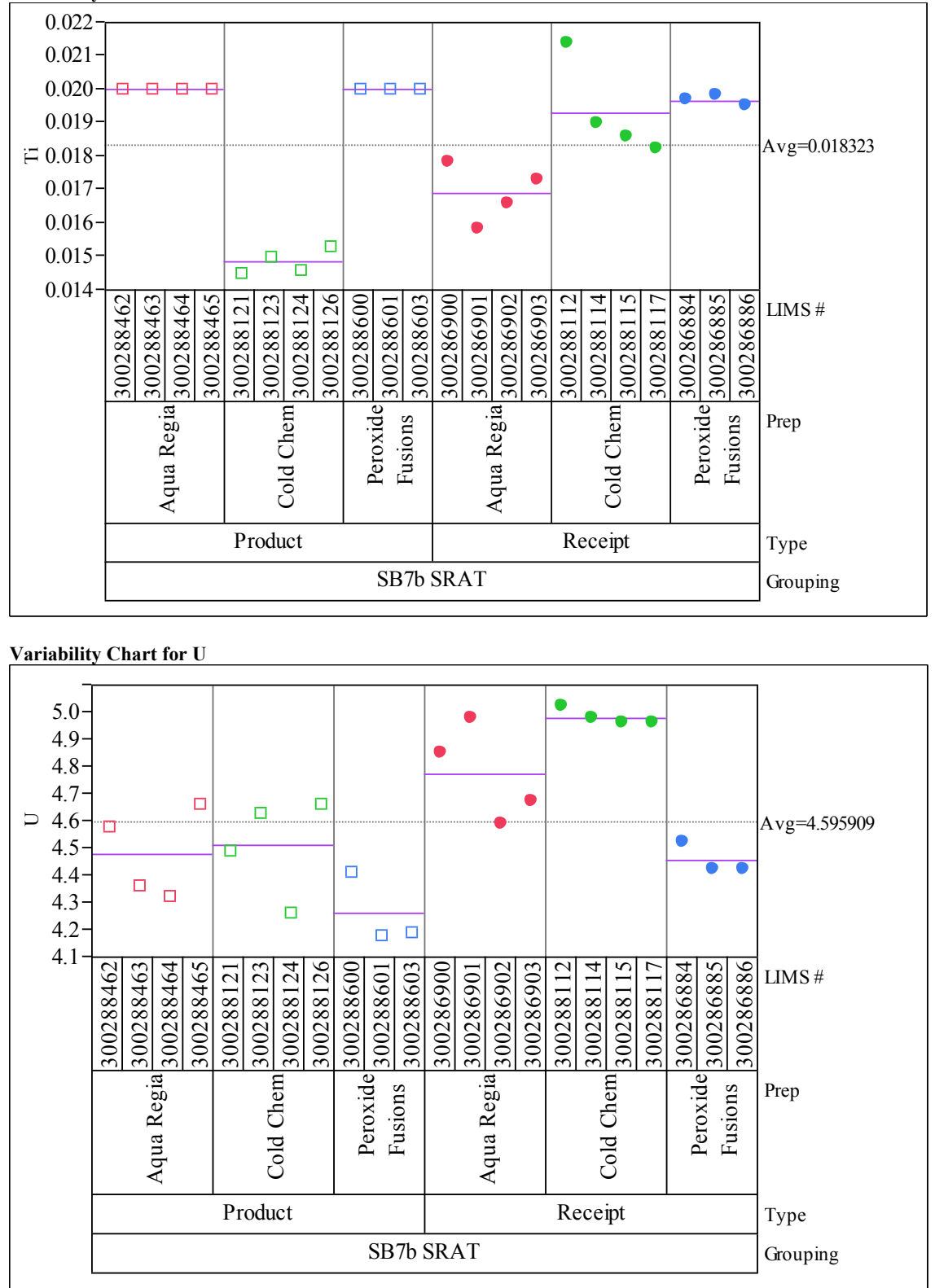
Variability Chart for Zr

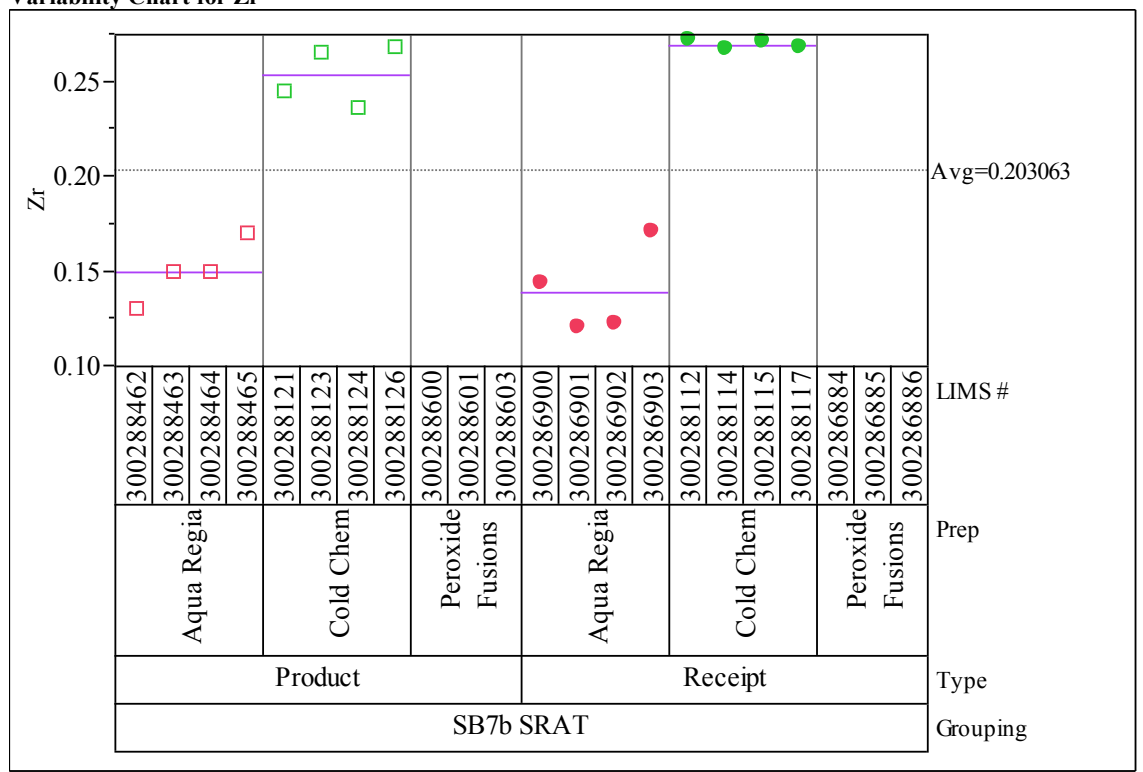


SRNL-STI-2011-00475, REVISION 0

Oneway Analysis of Al By Prep Grouping=SB7b SRAT, Type=Product

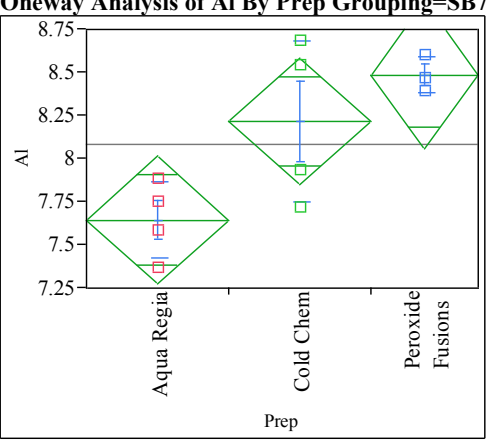

Oneway Anova

Summary of Fit

Rsquare $\quad 0.61932$

Root Mean Square Error $\quad 0.3195$

Mean of Response $\quad 8.082727$

Observations (or Sum Wgts) 11

Analysis of Variance

Source DF Sum of Squares Mean Square F Ratio Prob $>$ F

$\begin{array}{llrrrr}\text { Prep } & 2 & 1.3285765 & 0.664288 & 6.5075 & 0.0210\end{array}$

$\begin{array}{llll}\text { Error } & 8 & 0.8166417 & 0.102080\end{array}$

C. Total $10 \quad 2.1452182$

Means for Oneway Anova

$\begin{array}{lrrrrr}\text { Level } & \text { Number } & \text { Mean } & \text { Std Error } & \text { Lower 95\% } & \text { Upper 95\% } \\ \text { Aqua Regia } & 4 & 7.64500 & 0.15975 & 7.2766 & 8.0134 \\ \text { Cold Chem } & 4 & 8.21750 & 0.15975 & 7.8491 & 8.5859 \\ \text { Peroxide Fusions } & 3 & 8.48667 & 0.18446 & 8.0613 & 8.9120\end{array}$

Std Error uses a pooled estimate of error variance

Means and Std Deviations

Level Number Mean Std Dev Std Err Mean Lower 95\% Upper 95\%

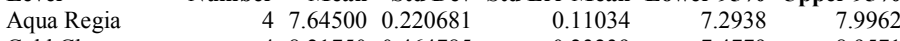

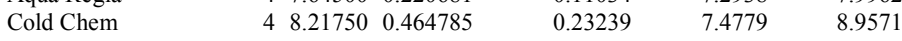

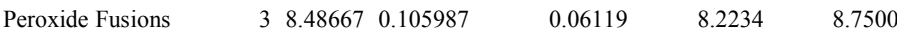

Tests that the Variances are Equal

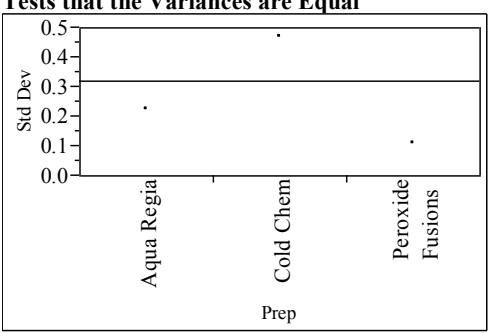

$\begin{array}{lrrrr}\text { Level } & \text { Count } & \text { Std Dev } & \text { MeanAbsDif to Mean } & \text { MeanAbsDif to Median } \\ \text { Aqua Regia } & 4 & 0.2206808 & 0.1700000 & 0.1700000 \\ \text { Cold Chem } & 4 & 0.4647849 & 0.3925000 & 0.3925000 \\ \text { Peroxide Fusions } & 3 & 0.1059874 & 0.0755556 & 0.0966667\end{array}$

F Ratio DFNum DFDen Prob $>$ F

$\begin{array}{lrrrr}\text { Test } & \text { F Ratio } & \text { DFNum } & \text { DFDen } & \text { Prob }>\text { F } \\ \text { O'Brien[.5] } & 5.4182 & 2 & 8 & 0.0325 \\ \text { Brown-Forsythe } & 10.3737 & 2 & 8 & 0.0060 \\ \text { Levene } & 11.3059 & 2 & 8 & 0.0047\end{array}$

$\begin{array}{lllll}\text { Bartlett } & 1.8682 & 2 & \text {. } & 0.1544\end{array}$

Warning: Small sample sizes. Use Caution.

Welch Anova testing Means Equal, allowing Std Devs Not Equal

F Ratio DFNum DFDen Prob $>$ F

$\begin{array}{llll}19.6462 & 2 & 4.9463 & 0.0044\end{array}$

Means Comparisons

Comparisons for all pairs using Tukey-Kramer HSD

Level

Peroxide Fusions A 8.4866667

Cold Chem A B 8.2175000

Aqua Regia $\quad$ B 7.6450000

Levels not connected by same letter are significantly different.
Oneway Analysis of B By Prep Grouping=SB7b SRAT, Type=Product

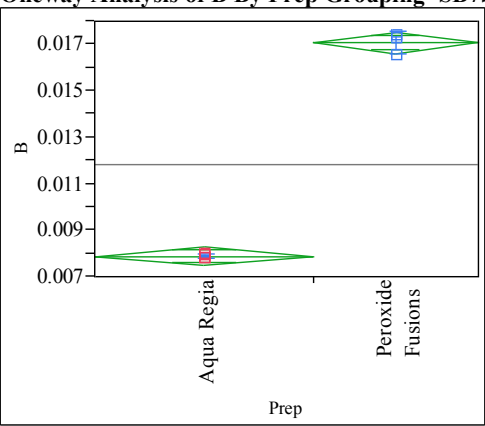

Missing Rows 4

Oneway Anova

Summary of Fit

Rsquare

Adj Rsquare $\quad 0.995956$

Root Mean Square Error $\quad 0.000313$

Mean of Response $\quad 0.011818$

Observations (or Sum Wgts) 7

Analysis of Variance

Source DF Sum of Squares Mean Square F Ratio Prob $>$ F

$\begin{array}{llllll}\text { Prep } & 1 & 0.00014514 & 0.000145 & 1478.793 & <.0001\end{array}$

$\begin{array}{llll}\text { Error } & 5 & 0.00000049 & 9.815 \mathrm{e}-8\end{array}$

C. Total $6 \quad 0.00014563$

Means for Oneway Anova

Level Number Mean Std Error Lower 95\% Upper 95\%

$\begin{array}{llllll}\text { Aqua Regia } & 4 & 0.007875 & 0.00016 & 0.00747 & 0.00828\end{array}$

Cold Chem

Peroxide Fusions

\begin{tabular}{lllll}
\hline & $0.01707 \dot{6}$ & 0.00018 & 0.01661 & $0.0175 \dot{4}^{\circ}$
\end{tabular}

Std Error uses a pooled estimate of error variance

Means and Std Deviations

Level Number Mean Std Dev Std Err Mean Lower 95\% Upper 95\%

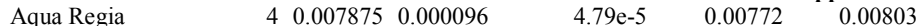

Cold Chr

Peroxide Fusion

.0077

.00803

Tests that the Variances are Equal

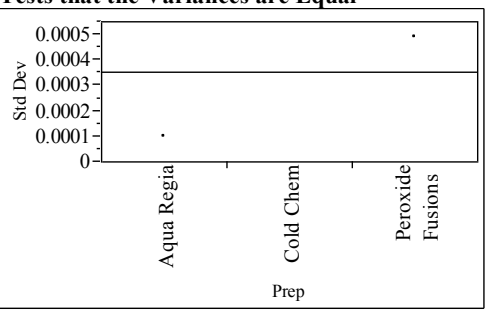

Level Count Std Dev MeanAbsDif to Mean MeanAbsDif to Median

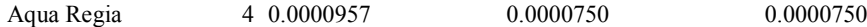

$\begin{array}{llll}\text { Cold Chem } & 0 & 0.0000000 & 0.0000000\end{array}$

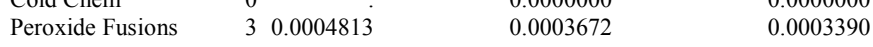

Test F Ratio DFNum DFDen Prob $>$ F

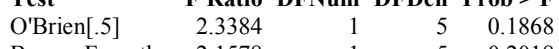

$\begin{array}{lllll}\text { Brown-Forsythe } & 2.1578 & 1 & 5 & 0.2018\end{array}$

$\begin{array}{lllll}\text { Levene } & 11.5000 & 1 & 5 & 0.0194\end{array}$

$\begin{array}{lllll}\text { Bartlett } & 4.4549 & 1 & . & 0.0348\end{array}$

Warning: Small sample sizes. Use Caution.

Welch Anova testing Means Equal, allowing Std Devs Not Equal

F Ratio DFNum DFDen Prob $>$ F

$\begin{array}{llll}1064.9960 & 1 & 2.1192 & 0.0007\end{array}$ 
SRNL-STI-2011-00475, REVISION 0

Oneway Analysis of Ca By Prep Grouping=SB7b SRAT, Type=Product

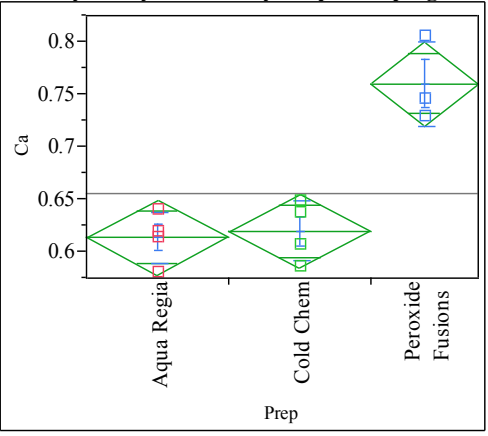

Oneway Anova

Summary of Fit

$\begin{array}{lr}\text { Rsquare } & 0.858524 \\ \text { Adj Rsquare } & 0.823155 \\ \text { Root Mean Square Error } & 0.030422 \\ \text { Mean of Response } & 0.655727 \\ \text { Observations (or Sum Wgts) } & 11\end{array}$

Analysis of Variance

Source DF Sum of Squares Mean Square F Ratio Prob $>$ F

$\begin{array}{llllll}\text { Prep } & 2 & 0.04492843 & 0.022464 & 24.2733 & 0.0004\end{array}$

$\begin{array}{llll}\text { Error } & 8 & 0.00740375 & 0.000925\end{array}$

$\begin{array}{lll}\text { C. Total } & 10 & 0.05233218\end{array}$

Means for Oneway Anova

$\begin{array}{lrrrrr}\text { Level } & \text { Number } & \text { Mean } & \text { Std Error } & \text { Lower 95\% } & \text { Upper 95\% } \\ \text { Aqua Regia } & 4 & 0.613500 & 0.01521 & 0.57842 & 0.64858 \\ \text { Cold Chem } & 4 & 0.619750 & 0.01521 & 0.58467 & 0.65483 \\ \text { Pel } & 3 & & & & 0.7650\end{array}$

0.01521

Std Error uses a pooled estimate of error variance

Means and Std Deviations

Level Number Mean Std Dev Std Err Mean Lower 95\% Upper 95\%

$\begin{array}{lllllll}\text { Aqua Regia } & 4 & 0.613500 & 0.024420 & 0.01221 & 0.57464 & 0.65236\end{array}$

$\begin{array}{lllllll}\text { Cold Chem } & 4 & 0.619750 & 0.028477 & 0.01424 & 0.57444 & 0.66506\end{array}$

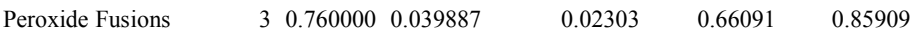

Tests that the Variances are Equal

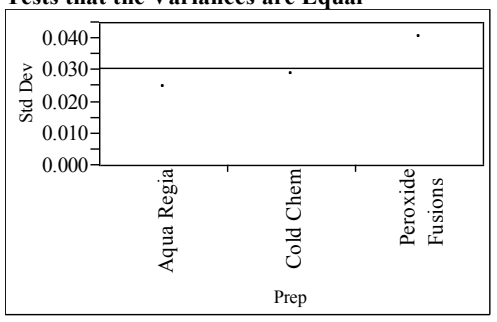

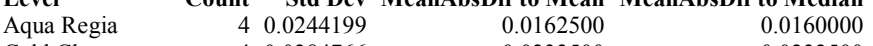

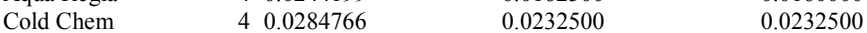

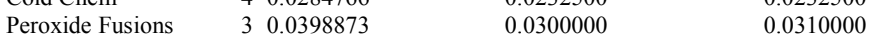

$\begin{array}{lrrrr}\text { Test } & \text { F Ratio } & \text { DFNum } & \text { DFDen } & \text { Prob }>\text { F } \\ \text { O'Brien[.5] } & 0.5822 & 2 & 8 & 0.5807 \\ \text { Brown-Forsythe } & 0.6804 & 2 & 8 & 0.5335 \\ \text { Levene } & 0.8813 & 2 & 8 & 0.4509 \\ \text { Bartlett } & 0.2689 & 2 & . & 0.7642\end{array}$

Warning: Small sample sizes. Use Caution.

Welch Anova testing Means Equal, allowing Std Devs Not Equal

F Ratio DFNum DFDen Prob $>$ F

$\begin{array}{llll}14.6815 & 2 & 4.5232 & 0.0105\end{array}$

Means Comparisons

Comparisons for all pairs using Tukey-Kramer HSD

Level

Mean

Peroxide Fusions A 0.76000000

Cold Chem $\quad$ B 0.61975000

Aqua Regia B 0.61350000

Levels not connected by same letter are significantly different.
Oneway Analysis of $\mathrm{Cr}$ By Prep Grouping=SB7b SRAT, Type=Product

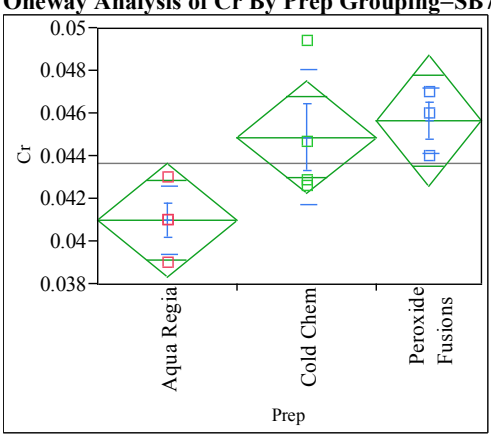

Oneway Anova

Summary of Fit

$\begin{array}{lr}\text { Rsquare } & 0.524084 \\ \text { Adj Rsquare } & 0.405104 \\ \text { Root Mean Square Error } & 0.002298 \\ \text { Mean of Response } & 0.043691 \\ \text { Observations (or Sum Wgts) } & 11\end{array}$

Analysis of Variance

Source DF Sum of Squares Mean Square F Ratio Prob $>$ F

$\begin{array}{llllll}\text { Prep } & 2 & 0.00004652 & 0.000023 & 4.4048 & 0.0513\end{array}$

$\begin{array}{llll}\text { Error } & 8 & 0.00004225 & 5.281 \mathrm{e}-6\end{array}$

C. Total $10 \quad 0.00008877$

Means for Oneway Anova

Level Number Mean Std Error Lower 95\% Upper 95\%

$\begin{array}{llllll}\text { Aqua Regia } & 4 & 0.041000 & 0.00115 & 0.03835 & 0.04365\end{array}$

$\begin{array}{llllll}\text { Cold Chem } & 4 & 0.044900 & 0.00115 & 0.04225 & 0.04755\end{array}$

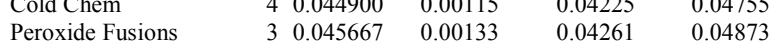

Std Error uses a pooled estimate of error variance

Means and Std Deviations

Level Number Mean Std Dev Std Err Mean Lower 95\% Upper 95\%

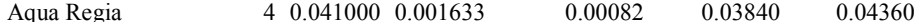

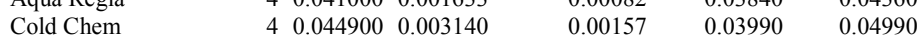

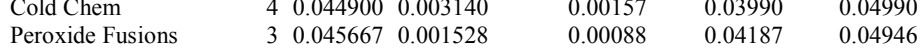

Tests that the Variances are Equal

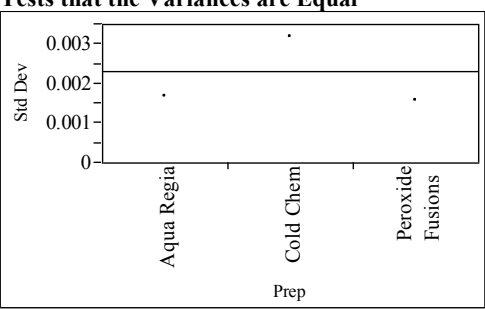

Level Count Std Dev MeanAbsDif to Mean MeanAbsDif to Median

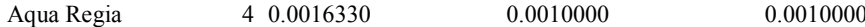

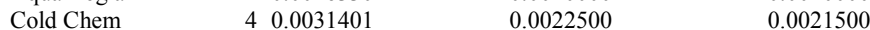

$\begin{array}{llll}\text { Peroxide Fusions } & 3 & 0.0015275 & 0.0011111\end{array}$

$\begin{array}{lrrrr}\text { Test } & \text { F Ratio } & \text { DFNum } & \text { DFDen } & \text { Prob }>\text { F } \\ \text { O'Brien[.5] } & 0.7659 & 2 & 8 & 0.4962 \\ \text { Brown-Forsythe } & 0.5384 & 2 & 8 & 0.6034 \\ \text { Levene } & 1.0358 & 2 & 8 & 0.3981 \\ \text { Bartlett } & 0.7712 & 2 & . & 0.4625\end{array}$

Warning: Small sample sizes. Use Caution.

Welch Anova testing Means Equal, allowing Std Devs Not Equal

F Ratio DFNum DFDen Prob $>$ F

$\begin{array}{llll}7.1397 & 2 & 5.0708 & 0.0335\end{array}$

Means Comparisons

Comparisons for all pairs using Tukey-Kramer HSD

Level

Mean

Peroxide Fusions A 0.04566667

Cold Chem A 0.04490000

Aqua Regia A 0.04100000

Levels not connected by same letter are significantly different. 
SRNL-STI-2011-00475, REVISION 0

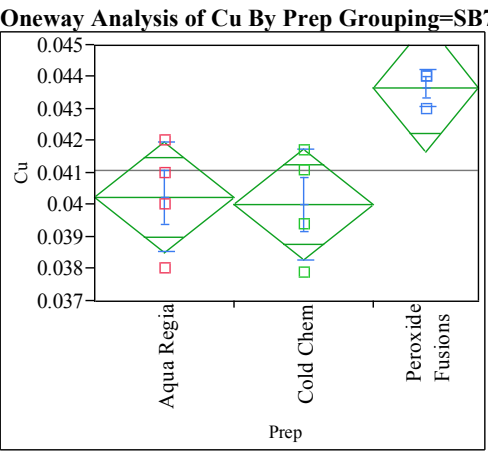

Oneway Anova

Summary of Fit

$\begin{array}{lr}\text { Rsquare } & 0.598679 \\ \text { Adj Rsquare } & 0.498349 \\ \text { Root Mean Square Error } & 0.001512 \\ \text { Mean of Response } & 0.0411 \\ \text { Observations (or Sum Wgts) } & 11\end{array}$

Analysis of Variance

Source DF Sum of Squares Mean Square F Ratio Prob $>$ F

$\begin{array}{llllll}\text { Prep } & 2 & 0.00002728 & 0.000014 & 5.9671 & 0.0259\end{array}$

Error $\quad 8 \quad 0.00001828 \quad 2.286 \mathrm{e}-6$

C. Total $10-0.00004556$

$\begin{array}{lrrrrr}\begin{array}{l}\text { Means for Oneway Anova } \\ \text { Level }\end{array} & & & & \\ \text { Number } & \text { Mean } & \text { Std Error } & \text { Lower 95\% } & \text { Upper 95\% } \\ \text { Aqua Regia } & 4 & 0.040250 & 0.00076 & 0.03851 & 0.04199 \\ \text { Cold Chem } & 4 & 0.040025 & 0.00076 & 0.03828 & 0.04177 \\ \text { Peroxide Fusions } & 3 & 0.043667 & 0.00087 & 0.04165 & 0.04568\end{array}$

Std Error uses a pooled estimate of error variance

Means and Std Deviations

Level Number Mean Std Dev Std Err Mean Lower 95\% Upper 95\%

$\begin{array}{lllllll}\text { Aqua Regia } & 4 & 0.040250 & 0.001708 & 0.00085 & 0.03753 & 0.04297\end{array}$

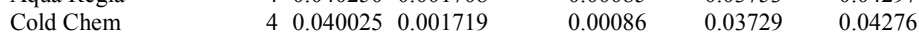

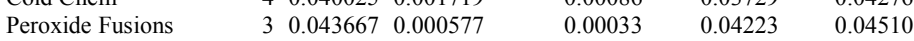

Tests that the Variances are Equal

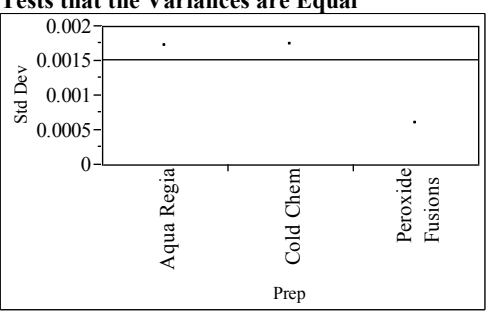

Level

Aqua Regia

Cold Chem

Count Std Dev MeanAbsDif to Mean MeanAbsDif to Median $4 \quad 0.0017078$

$\begin{array}{lll}4 & 0.0017193\end{array}$
0.0012500

0.0013750

0.0004444
30.0005774
0.0012500

0.0013750

0.0003333

$\begin{array}{lrrrr}\text { Test } & \text { F Ratio } & \text { DFNum } & \text { DFDen } & \text { Prob }>\text { F } \\ \text { O'Brien[.5] } & 0.8060 & 2 & 8 & 0.4798 \\ \text { Brown-Forsythe } & 1.7246 & 2 & 8 & 0.2384 \\ \text { Levene } & 1.7275 & 2 & 8 & 0.2379 \\ \text { Bartlett } & 1.0000 & 2 & . & 0.3679\end{array}$

Warning: Small sample sizes. Use Caution.

Welch Anova testing Means Equal, allowing Std Devs Not Equal

F Ratio DFNum DFDen Prob $>$ F

$\begin{array}{llll}11.4664 & 2 & 4.8685 & 0.0144\end{array}$

Means Comparisons

Comparisons for all pairs using Tukey-Kramer HSD

Level Mean

Peroxide Fusions A 0.04366667

Aqua Regia B 0.04025000

Cold Chem B 0.04002500

Levels not connected by same letter are significantly different.
Oneway Analysis of Fe By Prep Grouping=SB7b SRAT, Type=Product

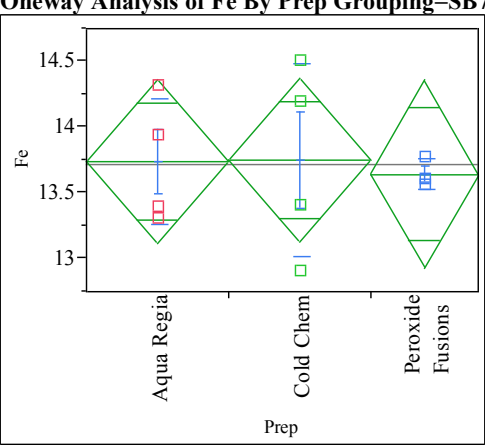

Oneway Anova

Summary of Fit

$\begin{array}{lr}\text { Rsquare } & 0.009525 \\ \text { Adj Rsquare } & -0.23809 \\ \text { Root Mean Square Error } & 0.539209 \\ \text { Mean of Response } & 13.71727 \\ \text { Observations (or Sum Wgts) } & 11\end{array}$

Analysis of Variance

Source DF Sum of Squares Mean Square F Ratio Prob $>$ F

$\begin{array}{llllll}\text { Prep } & 2 & 0.0223672 & 0.011184 & 0.0385 & 0.9624\end{array}$

$\begin{array}{llll}\text { Error } & 8 & 2.3259670 & 0.290746\end{array}$

C. Total $10 \quad 2.3483342$

Means for Oneway Anova

Level Number Mean Std Error Lower 95\% Upper 95\%

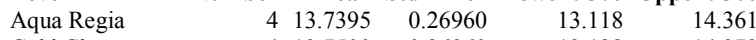

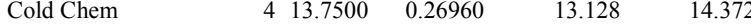

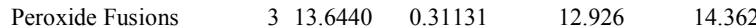

Std Error uses a pooled estimate of error variance

Means and Std Deviations

Level Number Mean Std Dev Std Err Mean Lower 95\% Upper 95\%

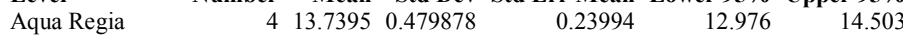

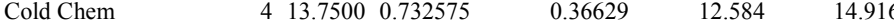

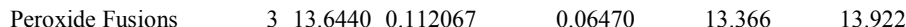

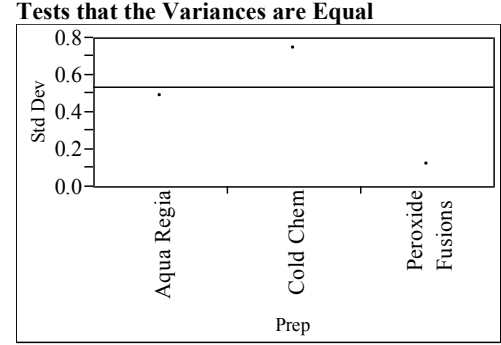

Level Count Std Dev MeanAbsDif to Mean MeanAbsDif to Median

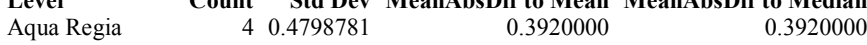

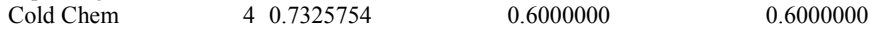

$\begin{array}{llll}\text { Peroxide Fusions } & 3 & 0.1120669 & 0.0846667\end{array}$

Test F Ratio DFNum DFDen Prob $>$ F

$\begin{array}{lllll}\text { O'Brien[.5] } & 2.3848 & 2 & 8 & 0.1540\end{array}$

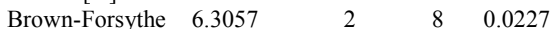

$\begin{array}{lllll}\text { Levene } & 7.2966 & 2 & 8 & 0.0157\end{array}$

$\begin{array}{lllll}\text { Bartlett } & 2.1918 & 2 & 0.1117\end{array}$

Warning: Small sample sizes. Use Caution.

Welch Anova testing Means Equal, allowing Std Devs Not Equal

F Ratio DFNum DFDen Prob $>$ F

$\begin{array}{rrrr}0.0952 & 2 & 4.3712 & 0.9110\end{array}$

Means Comparisons

Comparisons for all pairs using Tukey-Kramer HSD

Level Mean

Cold Chem A 13.750000

Aqua Regia A 13.739500

Peroxide Fusions A 13.644000

Levels not connected by same letter are significantly different. 
SRNL-STI-2011-00475, REVISION 0

Oneway Analysis of K By Prep Grouping=SB7b SRAT, Type=Product

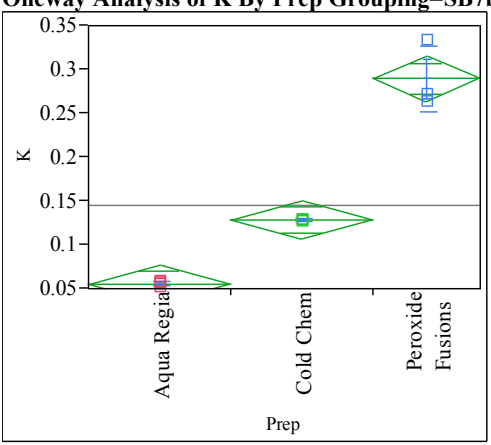

Oneway Anova

Summary of Fit

$\begin{array}{lr}\text { Rsquare } & 0.970568 \\ \text { Adj Rsquare } & 0.96321 \\ \text { Root Mean Square Error } & 0.01906 \\ \text { Mean of Response } & 0.145636 \\ \text { Observations (or Sum Wgts) } & 11\end{array}$

Analysis of Variance

Source DF Sum of Squares Mean Square F Ratio Prob $>$ F

$\begin{array}{lllllll}\text { Prep } & 2 & 0.09583438 & 0.047917 & 131.9049 & <.0001\end{array}$

Error $\quad 8 \quad 0.00290617$

C. Total $10 \quad 0.09874055$

Means for Oneway Anova

\begin{tabular}{lrrrrr} 
Level & Number & Mean & Std Error & Lower 95\% & Upper 95\% \\
Aqua Regia & 4 & 0.055250 & 0.00953 & 0.03327 & 0.07723 \\
Cold Chem & 4 & 0.128250 & 0.00953 & 0.10627 & 0.15023 \\
\hline
\end{tabular}

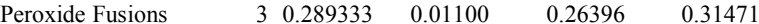

Std Error uses a pooled estimate of error variance

Means and Std Deviations

Level Number Mean Std Dev Std Err Mean Lower 95\% Upper 95\%

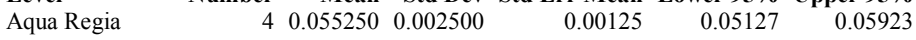

$\begin{array}{lllllll}\text { Cold Chem } & 4 & 0.128250 & 0.000957 & 0.00048 & 0.12673 & 0.12977\end{array}$

$\begin{array}{lllllll}\text { Peroxide Fusions } & 3 & 0.289333 & 0.037978 & 0.02193 & 0.19499 & 0.38368\end{array}$

Tests that the Variances are Equal

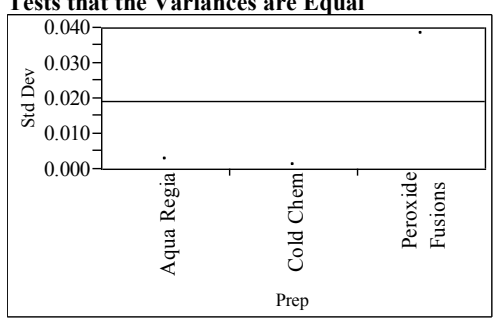

$\begin{array}{lrrrr}\text { Level } & \text { Count } & \text { Std Dev } & \text { MeanAbsDif to Mean } & \text { MeanAbsDif to Median } \\ \text { Aqua Regia } & 4 & 0.0025000 & 0.0017500 & 0.0017500 \\ \text { Cold Chem } & 4 & 0.0009574 & 0.0007500 & 0.0007500 \\ \text { Peroxide Fusions } & 3 & 0.0379781 & 0.0291111 & 0.0253333\end{array}$

Test F Ratio DFNum DFDen Prob $>$ F

$\begin{array}{lrrrr}\text { O'Brien[.5] } & 2.5730 & 2 & 8 & 0.1371 \\ \text { Brown-Forsythe } & 2.5047 & 2 & 8 & 0.1430 \\ \text { Levene } & 19.4175 & 2 & 8 & 0.0009 \\ \text { Bartlett } & 11.6633 & 2 & & <.0001\end{array}$

$<0001$

Warning: Small sample sizes. Use Caution.

Welch Anova testing Means Equal, allowing Std Devs Not Equal

F Ratio DFNum DFDen Prob $>$ F

$\begin{array}{llll}1275.4589 & 2 & 3.5152 & <.0001\end{array}$

Means Comparisons

Comparisons for all pairs using Tukey-Kramer HSD

Level Mean

Peroxide Fusions A $\quad 0.28933333$

$\begin{array}{lll}\text { Cold Chem } & \text { B } & 0.12825000\end{array}$

Aqua Regia C 0.05525000

Levels not connected by same letter are significantly different.
Oneway Analysis of Li By Prep Grouping=SB7b SRAT, Type=Product

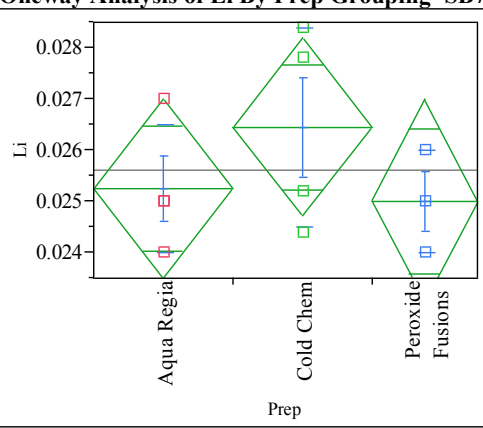

Oneway Anova

Summary of Fit

$\begin{array}{lr}\text { Rsquare } & 0.197216 \\ \text { Adj Rsquare } & -0.00348 \\ \text { Root Mean Square Error } & 0.001506 \\ \text { Mean of Response } & 0.025618 \\ \text { Observations (or Sum Wgts) } & 11\end{array}$

Analysis of Variance

Source DF Sum of Squares Mean Square F Ratio Prob $>$ F

$\begin{array}{llllll}\text { Prep } & 2 & 0.00000446 & 2.2282 \mathrm{e}-6 & 0.9827 & 0.4153\end{array}$

$\begin{array}{llll}\text { Error } & 8 & 0.00001814 & 2.2675 \mathrm{e}-6\end{array}$

C. Total $10 \quad 0.00002260$

Means for Oneway Anova

Level Number Mean Std Error Lower 95\% Upper 95\%

$\begin{array}{llllll}\text { Aqua Regia } & 4 & 0.025250 & 0.00075 & 0.02351 & 0.02699\end{array}$

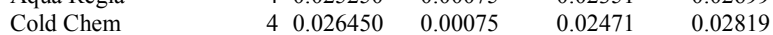

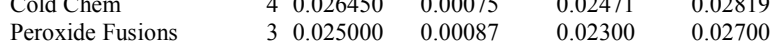

Std Error uses a pooled estimate of error variance

Means and Std Deviations

Level Number Mean Std Dev Std Err Mean Lower 95\% Upper 95\%

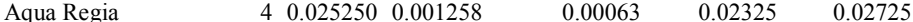

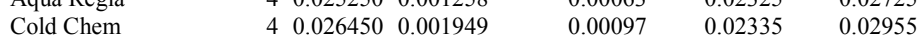

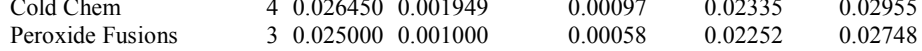

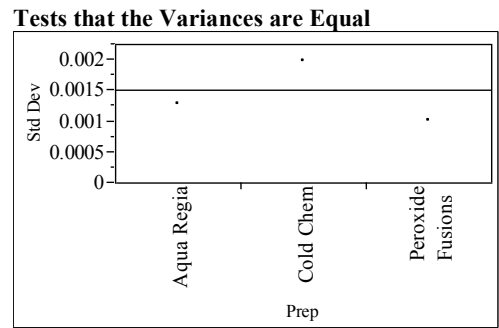

$\begin{array}{lrrrr}\text { Level } & \text { Count } & \text { Std Dev } & \text { MeanAbsDif to Mean } & \text { MeanAbsDif to Median } \\ \text { Aqua Regia } & 4 & 0.0012583 & 0.0008750 & 0.0007500 \\ \text { Cold Chem } & 4 & 0.0019485 & 0.0016500 & 0.0016500 \\ \text { Peroxide Fusions } & 3 & 0.0010000 & 0.0006667 & 0.0010000\end{array}$

Test F Ratio DFNum DFDen Prob $>$ F

$\begin{array}{lrrrr}\text { Test } & \text { F Ratio } & \text { DFNum } & \text { DFDen } & \text { Prob }>\text { F } \\ \text { O'Brien[.5] } & 1.7959 & 2 & 8 & 0.2269 \\ \text { Brown-Forsythe } & 2.0948 & 2 & 8 & 0.1855 \\ \text { Levene } & 2.7691 & 2 & 8 & 0.1219 \\ \text { Bartlett } & 0.4978 & 2 & . & 0.6079\end{array}$

Warning: Small sample sizes. Use Caution.

Welch Anova testing Means Equal, allowing Std Devs Not Equal

F Ratio DFNum DFDen Prob $>$ F

$\begin{array}{llll}0.7382 & 2 & 5.2324 & 0.5219\end{array}$

Means Comparisons

Comparisons for all pairs using Tukey-Kramer HSD

Level

A 0.02645000

Levels not connected by same letter are significantly different. 
SRNL-STI-2011-00475, REVISION 0

Oneway Analysis of Mg By Prep Grouping=SB7b SRAT, Type=Product

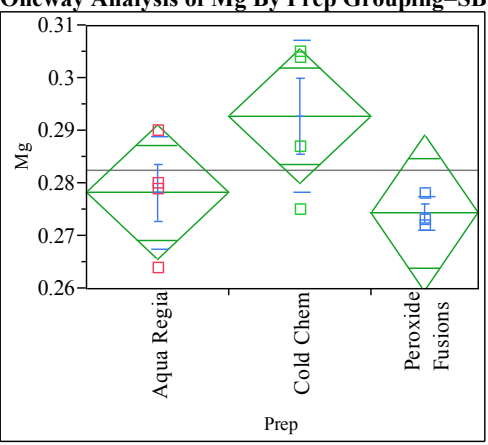

Oneway Anova

Summary of Fit

$\begin{array}{lr}\text { Rsquare } & 0.41157 \\ \text { Adj Rsquare } & 0.264463 \\ \text { Root Mean Square Error } & 0.011125 \\ \text { Mean of Response } & 0.282455 \\ \text { Observations (or Sum Wgts) } & 11\end{array}$

Analysis of Variance

Source DF Sum of Squares Mean Square F Ratio Prob $>$ F

$\begin{array}{llllll}\text { Prep } & 2 & 0.00069256 & 0.000346 & 2.7978 & 0.1199\end{array}$

Error $\quad 8 \quad 0.00099017$

C. Total $10 \quad 0.00168273$

Means for Oneway Anova

$\begin{array}{lrrrrr}\text { Level } & \text { Number } & \text { Mean } & \text { Std Error } & \text { Lower 95\% } & \text { Upper 95\% } \\ \text { Aqua Regia } & 4 & 0.278250 & 0.00556 & 0.26542 & 0.29108 \\ \text { Cold Chem } & 4 & 0.292750 & 0.00556 & 0.27992 & 0.30558 \\ \text { Peroxide Fusions } & 3 & 0.274333 & 0.00642 & 0.25952 & 0.28915\end{array}$

Peroxide Fusions $\quad 3 \quad 0.274333 \quad 0.00642-0.25952-0.28915$

Std Error uses a pooled estimate of error variance

Means and Std Deviations

Level Number Mean Std Dev Std Err Mean Lower 95\% Upper 95\%

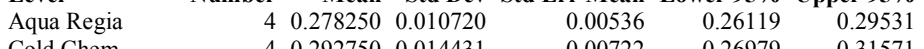
$\begin{array}{lllllll}\text { Cold Chem } & 4 & 0.292750 & 0.014431 & 0.00722 & 0.26979 & 0.31571\end{array}$ $\begin{array}{lllllll}\text { Peroxide Fusions } & 3 & 0.274333 & 0.003215 & 0.00186 & 0.26635 & 0.28232\end{array}$

Tests that the Variances are Equal

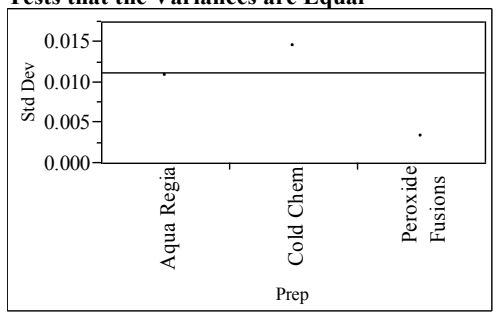

$\begin{array}{lrrrr}\text { Level } & \text { Count } & \text { Std Dev } & \text { MeanAbsDif to Mean } & \text { MeanAbsDif to Median } \\ \text { Aqua Regia } & 4 & 0.0107199 & 0.0071250 & 0.0067500 \\ \text { Cold Chem } & 4 & 0.0144309 & 0.0117500 & 0.0117500 \\ \text { Peroxide Fusions } & 3 & 0.0032146 & 0.0024444 & 0.0023333\end{array}$

Test F Ratio DFNum DFDen Prob $>$ F

$\begin{array}{lrrrr}\text { O'Brien[.5] } & 1.3460 & 2 & 8 & 0.3134 \\ \text { Brown-Forsythe } & 2.1885 & 2 & 8 & 0.1745 \\ \text { Levene } & 2.7563 & 2 & 8 & 0.1229 \\ \text { Bartlett } & 1.5456 & 2 & & 0.2132\end{array}$

Bartlett

Warning: Small sample sizes. Use Caution.

Welch Anova testing Means Equal, allowing Std Devs Not Equal

F Ratio DFNum DFDen Prob $>$ F

$\begin{array}{llrr}2.7742 & 2 & 4.607 & 0.1619\end{array}$

Means Comparisons

Comparisons for all pairs using Tukey-Kramer HSD

Level

Mean
A 0.29275000

Cold Chem

A 0.27825000

Peroxide Fusions A 0.27433333

Levels not connected by same letter are significantly different.
Oneway Analysis of Mn By Prep Grouping=SB7b SRAT, Type=Product

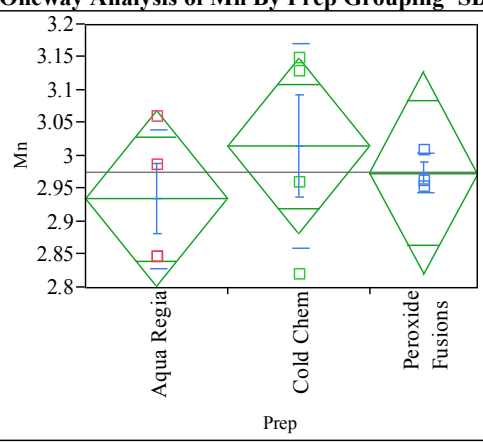

Oneway Anova

Summary of Fit

$\begin{array}{lr}\text { Rsquare } & 0.106136 \\ \text { Adj Rsquare } & -0.11733 \\ \text { Root Mean Square Error } & 0.116087 \\ \text { Mean of Response } & 2.974818 \\ \text { Observations (or Sum Wgts) } & 11\end{array}$

Analysis of Variance

Source DF Sum of Squares Mean Square F Ratio Prob $>$ F

$\begin{array}{llllll}\text { Prep } & 2 & 0.01280097 & 0.006400 & 0.4750 & 0.6384\end{array}$

$\begin{array}{llll}\text { Error } & 8 & 0.10780867 & 0.013476\end{array}$

C. Total $10 \quad 0.12060964$

Means for Oneway Anova

Level Number Mean Std Error Lower 95\% Upper 95\%

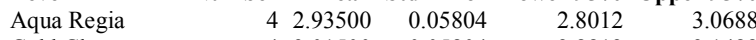

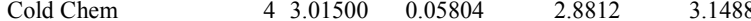

$\begin{array}{lllll}\text { Peroxide Fusions } & 3 & 2.97433 & 0.06702 & 2.8198\end{array}$

Std Error uses a pooled estimate of error variance

Means and Std Deviations

Level Number Mean Std Dev Std Err Mean Lower 95\% Upper 95\%

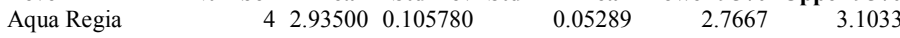

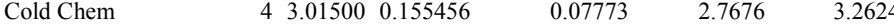

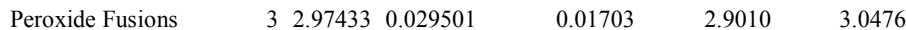

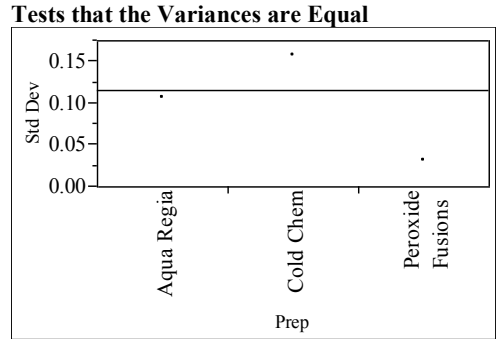

$\begin{array}{lrrrr}\text { Level } & \text { Count } & \text { Std Dev } & \text { MeanAbsDif to Mean } & \text { MeanAbsDif to Median } \\ \text { Aqua Regia } & 4 & 0.1057796 & 0.0880000 & 0.0880000 \\ \text { Cold Chem } & 4 & 0.1554563 & 0.1250000 & 0.1250000 \\ \text { Peroxide Fusions } & 3 & 0.0295014 & 0.0224444 & 0.0213333\end{array}$

$\begin{array}{lrrrr}\text { Test } & \text { F Ratio } & \text { DFNum } & \text { DFDen } & \text { Prob }>\text { F } \\ \text { O'Brien[.5] } & 1.8779 & 2 & 8 & 0.2145 \\ \text { Brown-Forsythe } & 4.0354 & 2 & 8 & 0.0614 \\ \text { Levene } & 5.6634 & 2 & 8 & 0.0294 \\ \text { Bartlett } & 1.8257 & 2 & . & 0.1611\end{array}$

Warning: Small sample sizes. Use Caution.

Welch Anova testing Means Equal, allowing Std Devs Not Equal

F Ratio DFNum DFDen Prob $>$ F

$\begin{array}{llll}0.3543 & 2 & 4.5137 & 0.7196\end{array}$

Means Comparisons

Comparisons for all pairs using Tukey-Kramer HSD

Leve Mean

Cold Chem A 3.0150000

Peroxide Fusions A 2.9743333

Aqua Regia A 2.9350000

Levels not connected by same letter are significantly different. 
SRNL-STI-2011-00475, REVISION 0

Oneway Analysis of Na By Prep Grouping=SB7b SRAT, Type=Product

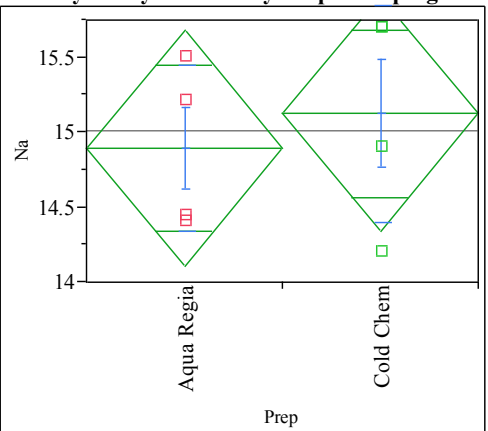

Missing Rows 3

Oneway Anova

Summary of Fit

$\begin{array}{lr}\text { Rsquare } & 0.041245 \\ \text { Adj Rsquare } & -0.11855 \\ \text { Root Mean Square Error } & 0.643016 \\ \text { Mean of Response } & 15.0095 \\ \text { Observations (or Sum Wgts) } & 8\end{array}$

Analysis of Variance

Source DF Sum of Squares Mean Square F Ratio Prob $>$ F

$\begin{array}{lllllll}\text { Prep } & 1 & 0.1067220 & 0.106722 & 0.2581 & 0.6296\end{array}$

$\begin{array}{llll}\text { Error } & 6 & 2.4808140 & 0.413469\end{array}$

$\begin{array}{lll}\text { C. Total } & 7 & 2.5875360\end{array}$

Means for Oneway Anova

Level Number Mean Std Error Lower 95\% Upper 95\%

$\begin{array}{llllll}\text { Aqua Regia } & 4 & 14.8940 & 0.32151 & 14.107 & 15.681\end{array}$

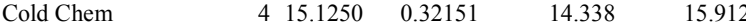

Peroxide Fusions

0 .

Std Error uses a pooled estimate of error variance

Means and Std Deviations

Level Number Mean Std Dev Std Err Mean Lower 95\% Upper 95\%

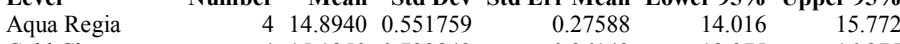

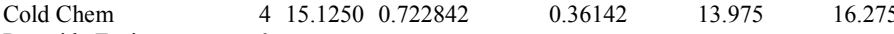

Peroxide Fusion

0

Tests that the Variances are Equal

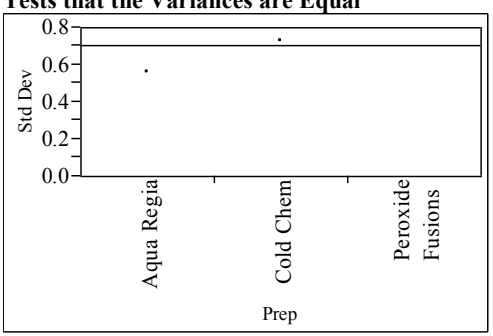

$\begin{array}{lrrrr}\text { Level } & \text { Count } & \text { Std Dev } & \text { MeanAbsDif to Mean } & \text { MeanAbsDif to Median } \\ \text { Aqua Regia } & 4 & 0.5517590 & 0.4660000 & 0.4660000 \\ \text { Cold Chem } & 4 & 0.7228416 & 0.5750000 & 0.5750000 \\ \text { Peroxide Fusions } & 0 & & 0.0000000 & 0.0000000\end{array}$

$\begin{array}{lrrrr}\text { Test } & \text { F Ratio } & \text { DFNum } & \text { DFDen } & \text { Prob }>\text { F } \\ \text { O'Brien[.5] } & 0.5430 & 1 & 6 & 0.4890 \\ \text { Brown-Forsythe } & 0.3329 & 1 & 6 & 0.5850 \\ \text { Levene } & 0.4922 & 1 & 6 & 0.5093 \\ \text { Bartlett } & 0.1853 & 1 & . & 0.6668\end{array}$

Warning: Small sample sizes. Use Caution.

Welch Anova testing Means Equal, allowing Std Devs Not Equal

F Ratio DFNum DFDen Prob $>$ F

$\begin{array}{rrrr}0.2581 & 1 & 5.6099 & 0.6308\end{array}$
Oneway Analysis of Ni By Prep Grouping=SB7b SRAT, Type=Product

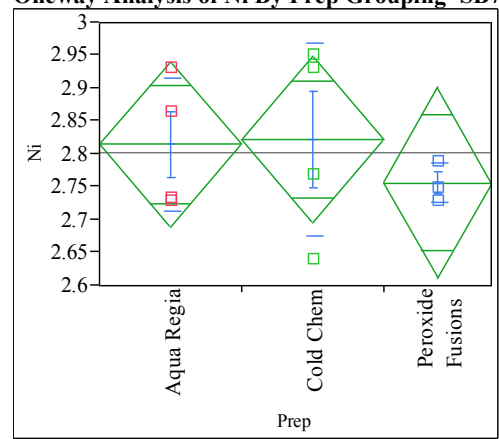

Oneway Anova

Summary of Fit

$\begin{array}{lr}\text { Rsquare } & 0.081113 \\ \text { Adj Rsquare } & -0.14861 \\ \text { Root Mean Square Error } & 0.109516 \\ \text { Mean of Response } & 2.801636 \\ \text { Observations (or Sum Wgts) } & 11\end{array}$

Analysis of Variance

Source DF Sum of Squares Mean Square F Ratio Prob $>$ F

$\begin{array}{llllll}\text { Prep } & 2 & 0.00846988 & 0.004235 & 0.3531 & 0.7129\end{array}$

$\begin{array}{llll}\text { Error } & 8 & 0.09595067 & 0.011994\end{array}$

C. Total $10 \quad 0.10442055$

Means for Oneway Anova

Level Number Mean Std Error Lower 95\% Upper 95\%

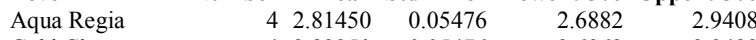

$\begin{array}{llllll}\text { Cold Chem } & 4 & 2.82250 & 0.05476 & 2.6962 & 2.9488\end{array}$

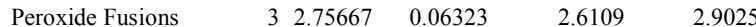

Std Error uses a pooled estimate of error variance

Means and Std Deviations

Level Number Mean Std Dev Std Err Mean Lower 95\% Upper 95\%

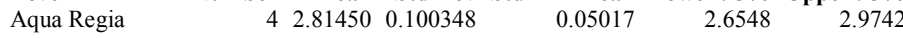

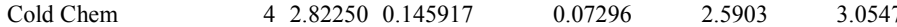

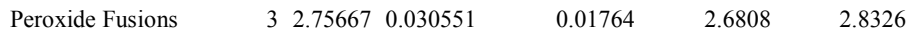

Tests that the Variances are Equal

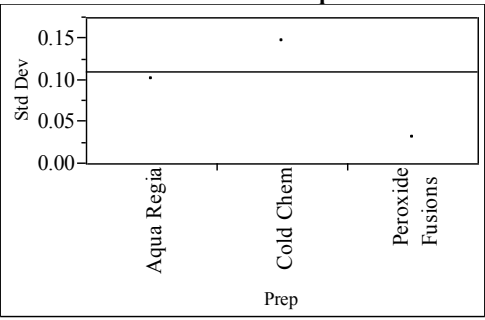

Level Count Std Dev MeanAbsDif to Mean MeanAbsDif to Median

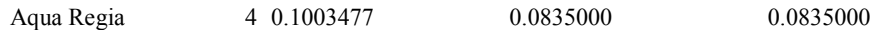

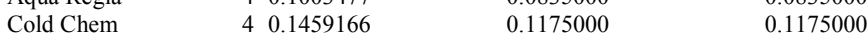

$\begin{array}{llll}\text { Peroxide Fusions } & 3 & 0.0305505 & 0.0222222\end{array}$

$\begin{array}{lrrrr}\text { Test } & \text { F Ratio } & \text { DFNum } & \text { DFDen } & \text { Prob }>\text { F } \\ \text { O'Brien[.5] } & 1.8618 & 2 & 8 & 0.2168 \\ \text { Brown-Forsythe } & 3.7174 & 2 & 8 & 0.0722 \\ \text { Levene } & 5.5238 & 2 & 8 & 0.0311 \\ \text { Bartlett } & 1.6656 & 2 & . & 0.1891\end{array}$

Warning: Small sample sizes. Use Caution.

Welch Anova testing Means Equal, allowing Std Devs Not Equal

F Ratio DFNum DFDen Prob $>$ F

$\begin{array}{llrr}0.7921 & 2 & 4.5952 & 0.5063\end{array}$

Means Comparisons

Comparisons for all pairs using Tukey-Kramer HSD

Level

Cold Chem A 2.8225000

Aqua Regia A 2.8145000

Peroxide Fusions A 2.7566667

Levels not connected by same letter are significantly different. 
SRNL-STI-2011-00475, REVISION 0

Oneway Analysis of Si By Prep Grouping=SB7b SRAT, Type=Product

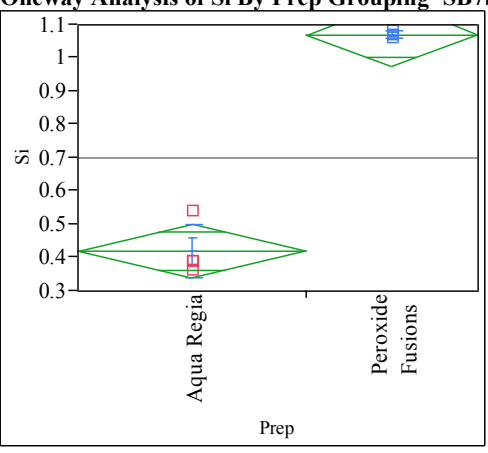

Missing Rows 4

Oneway Anova

Summary of Fit

$\begin{array}{lr}\text { Rsquare } & 0.973129 \\ \text { Adj Rsquare } & 0.967754 \\ \text { Root Mean Square Error } & 0.063246 \\ \text { Mean of Response } & 0.698571 \\ \text { Observations (or Sum Wgts) } & 7\end{array}$

Analysis of Variance

Source DF Sum of Squares Mean Square F Ratio Prob $>$ F

$\begin{array}{llllll}\text { Prep } & 1 & 0.72428571 & 0.724286 & 181.0714 & <.0001\end{array}$

$\begin{array}{llll}\text { Error } & 5 & 0.02000000 & 0.004000\end{array}$

C. Total $6 \quad 0.7442857$

Means for Oneway Anova

Level Number Mean Std Error Lower 95\% Upper 95\%

$\begin{array}{llllll}\text { Aqua Regia } & 4 & 0.42000 & 0.03162 & 0.33871 & 0.5013\end{array}$

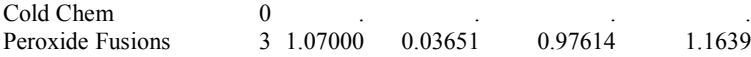

Std Error uses a pooled estimate of error variance

Means and Std Deviations

Level Number Mean Std Dev Std Err Mean Lower 95\% Upper 95\%

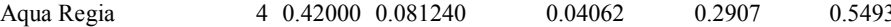

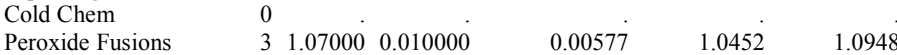

Tests that the Variances are Equal

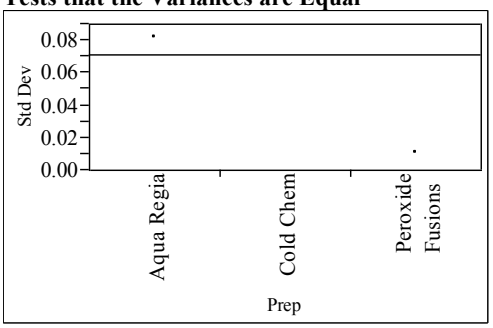

$\begin{array}{lrrrr}\text { Level } & \text { Count } & \text { Std Dev } & \text { MeanAbsDif to Mean } & \text { MeanAbsDif to Median } \\ \text { Aqua Regia } & 4 & 0.0812404 & 0.0600000 & 0.0450000 \\ \text { Cold Chem } & 0 & . & 0.0000000 & 0.0000000 \\ \text { Peroxide Fusions } & 3 & 0.0100000 & 0.0066667 & 0.0100000\end{array}$

$\begin{array}{lrrrr}\text { Test } & \text { F Ratio } & \text { DFNum } & \text { DFDen } & \text { Prob }>\text { F } \\ \text { O'Brien[.5] } & 1.0519 & 1 & 5 & 0.3521 \\ \text { Brown-Forsythe } & 0.6863 & 1 & 5 & 0.4452 \\ \text { Levene } & 4.4599 & 1 & 5 & 0.0884 \\ \text { Bartlett } & 4.8513 & 1 & . & 0.0276\end{array}$

Warning: Small sample sizes. Use Caution.

Welch Anova testing Means Equal, allowing Std Devs Not Equal

F Ratio DFNum DFDen Prob $>$ F

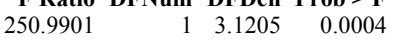

Oneway Analysis of Th By Prep Grouping=SB7b SRAT, Type=Product

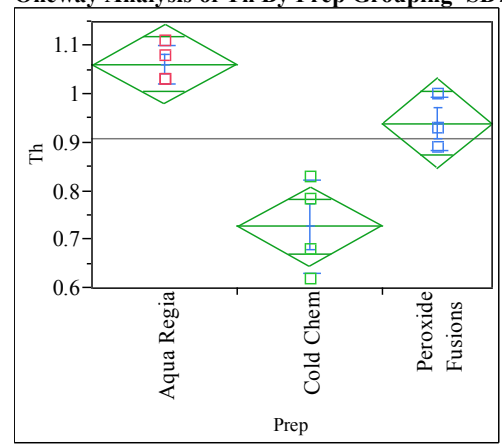

Oneway Anova

Summary of Fit

$\begin{array}{lr}\text { Rsquare } & 0.855208 \\ \text { Adj Rsquare } & 0.81901 \\ \text { Root Mean Square Error } & 0.069651 \\ \text { Mean of Response } & 0.907182 \\ \text { Observations (or Sum Wgts) } & 11\end{array}$

Observations (or Sum Wots) 0.907182

Analysis of Variance

Source DF Sum of Squares Mean Square F Ratio Prob $>$ F

$\begin{array}{llllll}\text { Prep } & 2 & 0.22922789 & 0.114614 & 23.6258 & 0.0004\end{array}$

$\begin{array}{llll}\text { Error } & 8 & 0.03880975 & 0.004851\end{array}$

C. Total $10 \quad 0.26803764$

Means for Oneway Anova

Level Number Mean Std Error Lower 95\% Upper 95\%

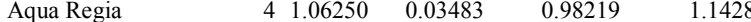

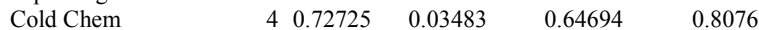

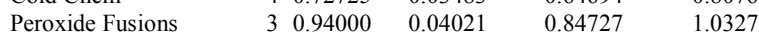

Std Error uses a pooled estimate of error variance

Means and Std Deviations

Level Number Mean Std Dev Std Err Mean Lower 95\% Upper 95\%

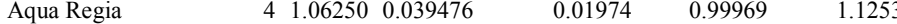

$\begin{array}{llllll}\text { Cold Chem } & 4 & 0.72725 & 0.096497 & 0.04825 & 0.57370\end{array}$

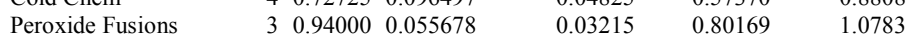

Tests that the Variances are Equal

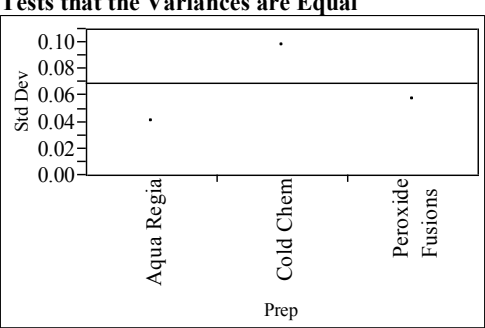

Count Std Dev MeanAbsDif to Mean MeanAbsDif to Median

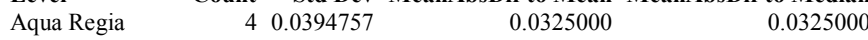

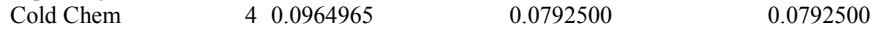

$\begin{array}{llll}\text { Peroxide Fusions } & 3 & 0.0556776 & 0.0400000\end{array}$

$\begin{array}{lrrrr}\text { Test } & \text { F Ratio } & \text { DFNum } & \text { DFDen } & \text { Prob }>\text { F } \\ \text { O'Brien[.5] } & 2.2531 & 2 & 8 & 0.1674 \\ \text { Brown-Forsythe } & 4.2922 & 2 & 8 & 0.0541 \\ \text { Levene } & 4.2217 & 2 & 8 & 0.0560 \\ \text { Bartlett } & 0.9997 & 2 & . & 0.3680\end{array}$

Warning: Small sample sizes. Use Caution.

Welch Anova testing Means Equal, allowing Std Devs Not Equal

F Ratio DFNum DFDen Prob $>$ F

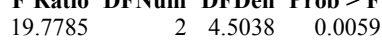

Means Comparisons

Comparisons for all pairs using Tukey-Kramer HSD

Level Mean

$\begin{array}{llr}\text { Aqua Regia } & \text { A } 1.0625000\end{array}$

Peroxide Fusions A 0.9400000

Cold Chem B 0.7272500

Levels not connected by same letter are significantly different. 
SRNL-STI-2011-00475, REVISION 0

Oneway Analysis of Ti By Prep Grouping=SB7b SRAT, Type=Product

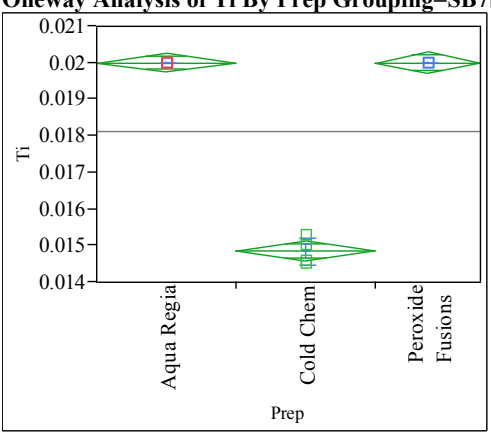

Oneway Anova

Summary of Fit

$\begin{array}{lr}\text { Rsquare } & 0.993964 \\ \text { Adj Rsquare } & 0.992455 \\ \text { Root Mean Square Error } & 0.000226 \\ \text { Mean of Response } & 0.018127 \\ \text { Observations (or Sum Wgts) } & 11\end{array}$

Analysis of Variance

Source DF Sum of Squares Mean Square F Ratio Prob $>$ F

$\begin{array}{llllll}\text { Prep } & 2 & 0.00006751 & 0.000034 & 658.6519 & <.0001\end{array}$

$\begin{array}{llll}\text { Error } & 8 & 0.00000041 & 5.125 \mathrm{e}-8\end{array}$

C. Total $10-0.00006792$

$\begin{array}{lrrrrr}\begin{array}{l}\text { Means for Oneway Anova } \\ \text { Level }\end{array} & & & & \\ \text { Number } & \text { Mean } & \text { Std Error } & \text { Lower 95\% } & \text { Upper 95\% } \\ \text { Aqua Regia } & 4 & 0.020000 & 0.00011 & 0.01974 & 0.02026 \\ \text { Cold Chem } & 4 & 0.014850 & 0.00011 & 0.01459 & 0.01511 \\ \text { Peroxide Fusions } & 3 & 0.020000 & 0.00013 & 0.01970 & 0.02030\end{array}$

Std Error uses a pooled estimate of error variance

Means and Std Deviations

Level Number Mean Std Dev Std Err Mean Lower 95\% Upper 95\%

$\begin{array}{lllllll}\text { Aqua Regia } & 4 & 0.020000 & 0.000000 & 0.00000 & 0.02000 & 0.02000\end{array}$

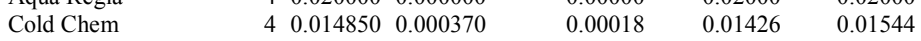

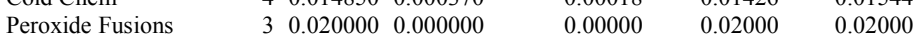

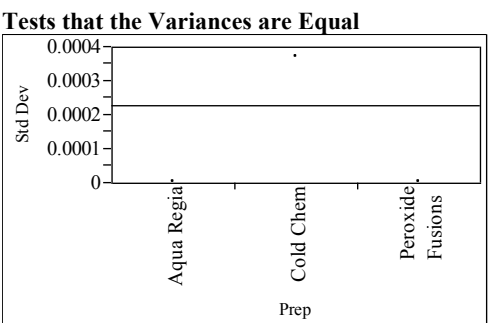

$\begin{array}{lrrrr}\text { Level } & \text { Count } & \text { Std Dev } & \text { MeanAbsDif to Mean } & \text { MeanAbsDif to Median } \\ \text { Aqua Regia } & 4 & 0.0000000 & 0.0000000 & 0.0000000 \\ \text { Cold Chem } & 4 & 0.0003697 & 0.0003000 & 0.0003000 \\ \text { Peroxide Fusions } & 3 & 0.0000000 & 0.0000000 & 0.0000000\end{array}$

Test F Ratio DFNum DFDen Prob $>$ F

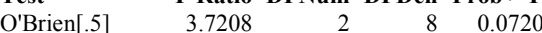

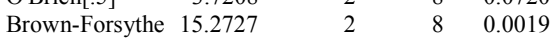

$\begin{array}{lllll}\text { Levene } & 18.3273 & 2 & 8 & 0.0010\end{array}$

Bartlett . 2.

Warning: Small sample sizes. Use Caution.

Welch Anova testing Means Equal, allowing Std Devs Not Equal

F Ratio DFNum DFDen Prob $>$ F

2

Means Comparisons

Comparisons for all pairs using Tukey-Kramer HSD

Level

Mean

Aqua Regia A $\quad 0.02000000$

Peroxide Fusions A 0.02000000

Cold Chem B 0.01485000

Levels not connected by same letter are significantly different.
Oneway Analysis of U By Prep Grouping=SB7b SRAT, Type=Product

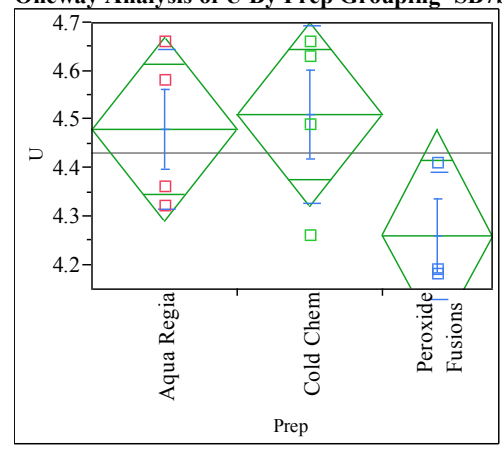

Oneway Anova

Summary of Fit

$\begin{array}{lr}\text { Rsquare } & 0.361496 \\ \text { Adj Rsquare } & 0.20187 \\ \text { Root Mean Square Error } & 0.164317 \\ \text { Mean of Response } & 4.430909 \\ \text { Observations (or Sum Wgts) } & 11\end{array}$

Analysis of Variance

Source DF Sum of Squares Mean Square F Ratio Prob $>$ F

$\begin{array}{llllll}\text { Prep } & 2 & 0.12229091 & 0.061145 & 2.2646 & 0.1662\end{array}$

$\begin{array}{llll}\text { Error } & 8 & 0.21600000 & 0.027000\end{array}$

C. Total $10 \quad 0.33829091$

Means for Oneway Anova

Level Number Mean Std Error Lower 95\% Upper 95\%

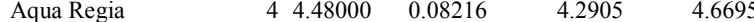

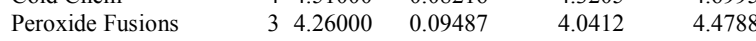

Std Error uses a pooled estimate of error variance

Means and Std Deviations

Level Number Mean Std Dev Std Err Mean Lower 95\% Upper 95\%

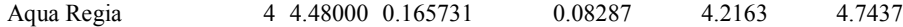

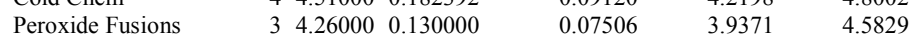

Tests that the Variances are Equal

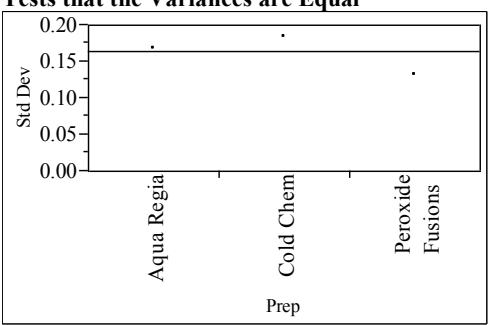

Level Count Std Dev MeanAbsDif to Mean MeanAbsDif to Median

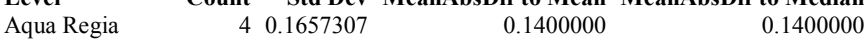

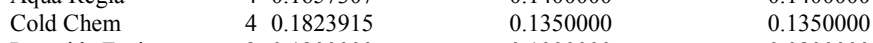

$\begin{array}{llll}\text { Peroxide Fusions } & 3 & 0.1300000 & 0.1000000\end{array}$

$\begin{array}{lrrrr}\text { Test } & \text { F Ratio } & \text { DFNum } & \text { DFDen } & \text { Prob }>\text { F } \\ \text { O'Brien[.5] } & 0.2388 & 2 & 8 & 0.7930 \\ \text { Brown-Forsythe } & 0.4110 & 2 & 8 & 0.6763 \\ \text { Levene } & 0.3594 & 2 & 8 & 0.7088 \\ \text { Bartlett } & 0.1105 & 2 & . & 0.8953\end{array}$

Warning: Small sample sizes. Use Caution.

Welch Anova testing Means Equal, allowing Std Devs Not Equal

F Ratio DFNum DFDen Prob $>$ F

$\begin{array}{rrrr}2.6031 & 2 & 5.258 & 0.1638\end{array}$

Means Comparisons

Comparisons for all pairs using Tukey-Kramer HSD

Level Mean

Cold Chem A 4.5100000

Aqua Regia A 4.4800000

Peroxide Fusions A 4.2600000

Levels not connected by same letter are significantly different. 
SRNL-STI-2011-00475, REVISION 0

Oneway Analysis of Zr By Prep Grouping=SB7b SRAT, Type=Product

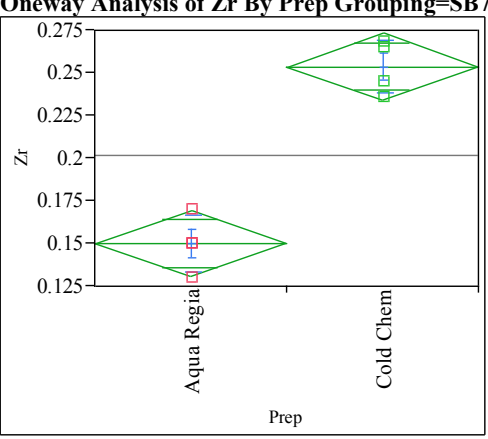

Missing Rows 3

Oneway Anova

Summary of Fit

$\begin{array}{lr}\text { Rsquare } & 0.933712 \\ \text { Adj Rsquare } & 0.922665 \\ \text { Root Mean Square Error } & 0.015922 \\ \text { Mean of Response } & 0.20175 \\ \text { Observations (or Sum Wgts) } & 8\end{array}$

Analysis of Variance

Source DF Sum of Squares Mean Square F Ratio Prob $>$ F

$\begin{array}{lllllll}\text { Prep } & 1 & 0.02142450 & 0.021424 & 84.5148 & <.0001\end{array}$

$\begin{array}{llll}\text { Error } & 6 & 0.00152100 & 0.000254\end{array}$

C. Total $7 \quad 0.02294550$

Means for Oneway Anova

Level Number Mean Std Error Lower 95\% Upper 95\%

$\begin{array}{llllll}\text { Aqua Regia } & 4 & 0.150000 & 0.00796 & 0.13052 & 0.16948\end{array}$

Cold Chem

Peroxide Fusion

$\begin{array}{lll}4 & 0.253500 \quad 0.00796\end{array}$

0.23402

0.27298

Std Error uses a pooled estimate of error variance

Means and Std Deviations

Level Number Mean Std Dev Std Err Mean Lower 95\% Upper 95\%

$\begin{array}{lllllll}\text { Aqua Regia } & 4 & 0.150000 & 0.016330 & 0.00816 & 0.12402 & 0.17598\end{array}$

$\begin{array}{lllllll}\text { Cold Chem } & 4 & 0.253500 & 0.015503 & 0.00775 & 0.22883 & 0.27817\end{array}$

Peroxide Fusions

0

Tests that the Variances are Equal

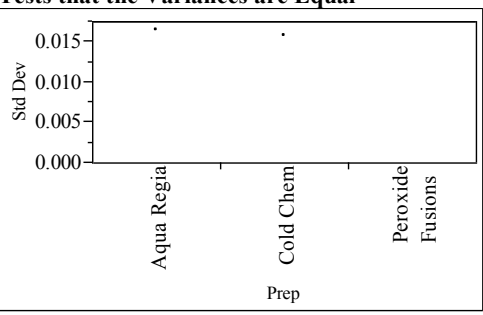

$\begin{array}{lrrrr}\text { Level } & \text { Count } & \text { Std Dev } & \text { MeanAbsDif to M } \\ \text { Aqua Regia } & 4 & 0.0163299 & & 0.010 \\ \text { Cold Chem } & 4 & 0.0155027 & & 0.01300 \\ \text { Peroxide Fusions } & 0 & . & & 0.00000 \\ & & & & \\ \text { Test } & \text { F Ratio } & \text { DFNum } & \text { DFDen } & \text { Prob > F } \\ \text { O'Brien[.5] } & 0.0157 & 1 & 6 & 0.9044 \\ \text { Brown-Forsythe } & 0.2379 & 1 & 6 & 0.6430 \\ \text { Levene } & 0.2427 & 1 & 6 & 0.6398 \\ \text { Bartlett } & 0.0069 & 1 & . & 0.9336\end{array}$

Warning: Small sample sizes. Use Caution.

Welch Anova testing Means Equal, allowing Std Devs Not Equal

F Ratio DFNum DFDen Prob $>$ F

$\begin{array}{llll}84.5148 & 1 & 5.9839 & <.0001\end{array}$
Oneway Analysis of Al By Prep Grouping=SB7b SRAT, Type=Receipt

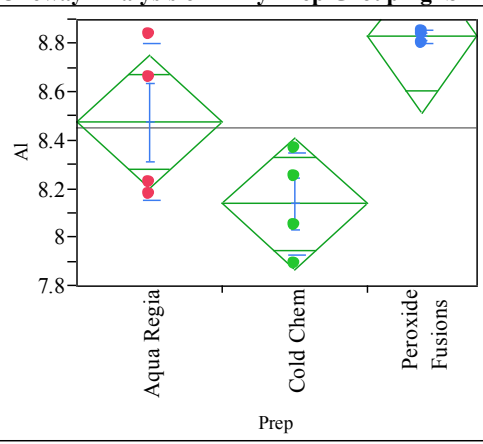

Oneway Anova

Summary of Fit

$\begin{array}{lr}\text { Rsquare } & 0.645092 \\ \text { Adj Rsquare } & 0.556365 \\ \text { Root Mean Square Error } & 0.237559 \\ \text { Mean of Response } & 8.450909 \\ \text { Observations (or Sum Wgts) } & 11\end{array}$

Analysis of Variance

Source DF Sum of Squares Mean Square F Ratio Prob $>$ F

$\begin{array}{llllll}\text { Prep } & 2 & 0.8206159 & 0.410308 & 7.2705 & 0.0159\end{array}$

$\begin{array}{llll}\text { Error } & 8 & 0.4514750 & 0.056434\end{array}$

C. Total $10 \quad 1.2720909$

Means for Oneway Anova

Level Number Mean Std Error Lower 95\% Upper 95\%

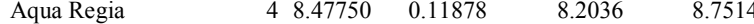

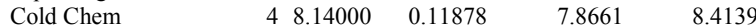

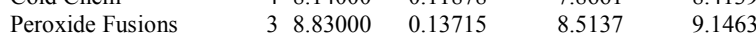

Std Error uses a pooled estimate of error variance

Means and Std Deviations

Level Number Mean Std Dev Std Err Mean Lower 95\% Upper 95\%

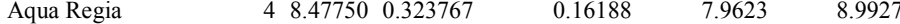

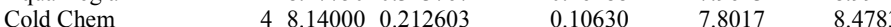

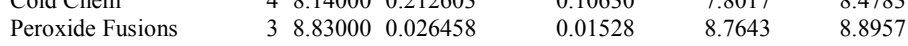

Tests that the Variances are Equal

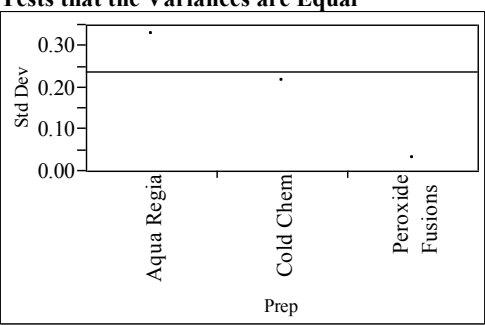

Level Count Std Dev MeanAbsDif to Mean MeanAbsDif to Median

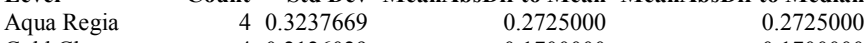

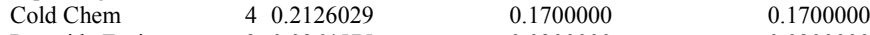

$\begin{array}{llll}\text { Peroxide Fusions } & 3 & 0.0264575 & 0.0200000\end{array}$

Test F Ratio DFNum DFDen Prob $>$ F

$\begin{array}{lllll}\text { O'Brien[.5] } & 3.6496 & 2 & 8 & 0.0748\end{array}$

$\begin{array}{llll}\text { Brown-Forsythe } 10.2523 & 2 & 8 & 0.0062\end{array}$

$\begin{array}{lrrrr}\text { Levene } & 11.6207 & 2 & 8 & 0.0043\end{array}$

$\begin{array}{lllll}\text { Bartlett } & 3.2327 & 2 & 0.0395\end{array}$

Warning: Small sample sizes. Use Caution.

Welch Anova testing Means Equal, allowing Std Devs Not Equal

F Ratio DFNum DFDen Prob $>$ F

$19.6278 \quad 2 \quad 4.1146 \quad 0.0079$

Means Comparisons

Comparisons for all pairs using Tukey-Kramer HSD

Level Mean

Peroxide Fusions A 8.8300000

Aqua Regia A B 8.4775000

Cold Chem B 8.1400000

Levels not connected by same letter are significantly different. 
SRNL-STI-2011-00475, REVISION 0

Oneway Analysis of B By Prep Grouping=SB7b SRAT, Type=Receipt

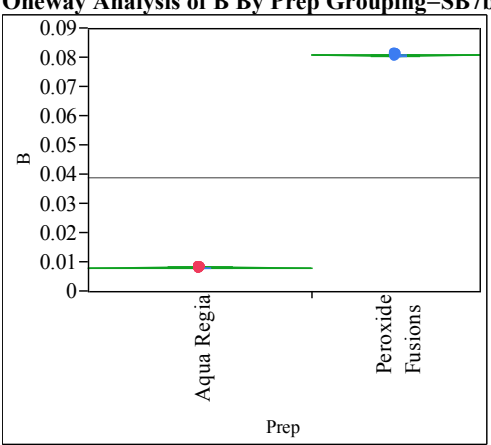

Missing Rows 4

Oneway Anova

Summary of Fit

Adj Rsquare

0.999962

Root Mean S

0.999955

Square Error $\quad 0.000262$

Mean of Response 0.039244

Observations (or Sum Wgts)

Analysis of Variance

Source DF Sum of Squares Mean Square F Ratio Prob $>$ F

$\begin{array}{lllllll}\text { Prep } & 1 & 0.00905157 & 0.009052 & 131892.6 & <.0001\end{array}$

$\begin{array}{lll}\text { Error } & 5 & 0.00000034\end{array}$

C. Total $6 \quad 0.00905191$

Means for Oneway Anova

$\begin{array}{lrrrrr}\text { Level } & \text { Number } & \text { Mean } & \text { Std Error } & \text { Lower 95\% } & \text { Upper 95\% } \\ \text { Aqua Regia } & 4 & 0.008102 & 0.00013 & 0.00777 & 0.00844 \\ \text { Cold Chem } & 0 & . & . & . & . \\ \text { Peroxide Fusions } & 3 & 0.080767 & 0.00015 & 0.08038 & 0.08116\end{array}$

Std Error uses a pooled estimate of error variance

Means and Std Deviations

Level Number Mean Std Dev Std Err Mean Lower 95\% Upper 95\%

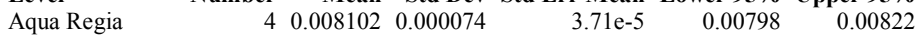

Cold Chem

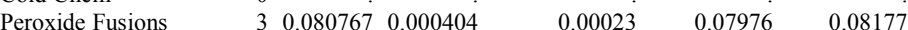

Tests that the Variances are Equal

\begin{tabular}{|l|l|l||}
\hline & & \\
\hline
\end{tabular}

$\begin{array}{lrrrr}\text { Level } & \text { Count } & \text { Std Dev } & \text { MeanAbsDif to Mean } & \text { MeanAbsDif to Median } \\ \text { Aqua Regia } & 4 & 0.0000741 & 0.0000525 & 0.0000525 \\ \text { Cold Chem } & 0 & . & 0.0000000 & 0.0000000 \\ \text { Peroxide Fusions } & 3 & 0.0004041 & 0.0003111 & 0.0002333\end{array}$

Test F Ratio DFNum DFDen Prob $>$ F

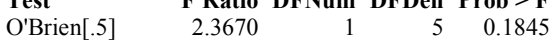

Brown-Forsythe $0.8409 \quad 1 \quad 50.4012$

$\begin{array}{lllll}\text { Levene } & 13.7319 & 1 & 5 & 0.0139\end{array}$

$\begin{array}{lrrrr}\text { Bartlett } & 4.8239 & 1 & \text {. } & 0.0281\end{array}$

Warning: Small sample sizes. Use Caution.

Welch Anova testing Means Equal, allowing Std Devs Not Equal

F Ratio DFNum DFDen Prob $>$ F

$\begin{array}{llll}94595.678 & 1 & 2.1012 & <.0001\end{array}$
Oneway Analysis of Ca By Prep Grouping=SB7b SRAT, Type=Receipt

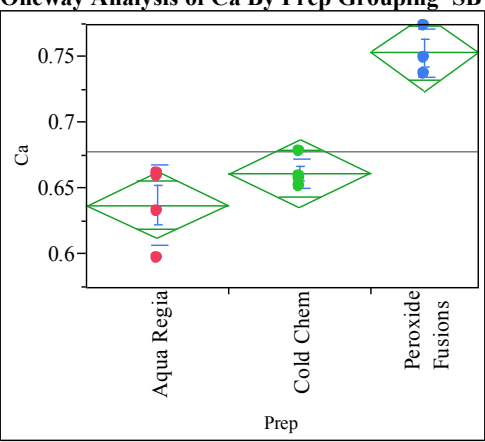

Oneway Anova

Summary of Fit

$\begin{array}{lr}\text { Rsquare } & 0.865427 \\ \text { Adj Rsquare } & 0.831784 \\ \text { Root Mean Square Error } & 0.021864 \\ \text { Mean of Response } & 0.677909 \\ \text { Observations (or Sum Wgts) } & 11\end{array}$

Analysis of Variance

Source DF Sum of Squares Mean Square F Ratio Prob $>$ F

$\begin{array}{lllllll}\text { Prep } & 2 & 0.02459449 & 0.012297 & 25.7237 & 0.0003\end{array}$

$\begin{array}{llll}\text { Error } & 8 & 0.00382442 & 0.000478\end{array}$

C. Total $10 \quad 0.02841891$

Means for Oneway Anova

Level Number Mean Std Error Lower 95\% Upper 95\%

$\begin{array}{lllrrr}\text { Aqua Regia } & 4 & 0.637750 & 0.01093 & 0.61254 & 0.66296\end{array}$

$\begin{array}{llllll}\text { Cold Chem } & 4 & 0.661500 & 0.01093 & 0.63629 & 0.68671\end{array}$

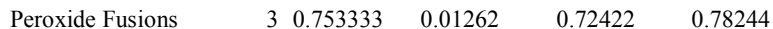

Std Error uses a pooled estimate of error variance

Means and Std Deviations

Level Number Mean Std Dev Std Err Mean Lower 95\% Upper 95\%

$\begin{array}{llllllr}\text { Aqua Regia } & 4 & 0.637750 & 0.030126 & 0.01506 & 0.58981 & 0.68569\end{array}$

$\begin{array}{lllllll}\text { Cold Chem } & 4 & 0.661500 & 0.011387 & 0.00569 & 0.64338 & 0.67962\end{array}$

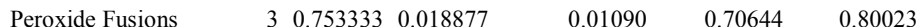

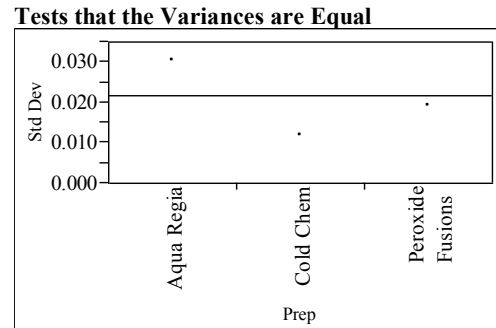

$\begin{array}{lrrrr}\text { Level } & \text { Count } & \text { Std Dev } & \text { MeanAbsDif to Mean } & \text { MeanAbsDif to Median } \\ \text { Aqua Regia } & 4 & 0.0301261 & 0.0227500 & 0.0227500 \\ \text { Cold Chem } & 4 & 0.0113871 & 0.0082500 & 0.0070000 \\ \text { Peroxide Fusions } & 3 & 0.0188768 & 0.0137778 & 0.0163333\end{array}$

Test F Ratio DFNum DFDen Prob $>$ F

$\begin{array}{lrrrr}\text { O'Brien[.5] } & 1.1041 & 2 & 8 & 0.3772 \\ \text { Brown-Forsythe } & 1.5656 & 2 & 8 & 0.2668 \\ \text { Levene } & 1.8718 & 2 & 8 & 0.2154\end{array}$

$\begin{array}{llll}\text { Bartlett } & 1.0986 & 2 & 0.3333\end{array}$

Warning: Small sample sizes. Use Caution.

Welch Anova testing Means Equal, allowing Std Devs Not Equal

F Ratio DFNum DFDen Prob $>$ F

$\begin{array}{llll}27.3596 & 2 & 4.2734 & 0.0037\end{array}$

Means Comparisons

Comparisons for all pairs using Tukey-Kramer HSD

Level

Mean

Peroxide Fusions A 0.75333333

Cold Chem B 0.66150000

Aqua Regia B 0.63775000

Levels not connected by same letter are significantly different. 
SRNL-STI-2011-00475, REVISION 0

Oneway Analysis of Cr By Prep Grouping=SB7b SRAT, Type=Receipt

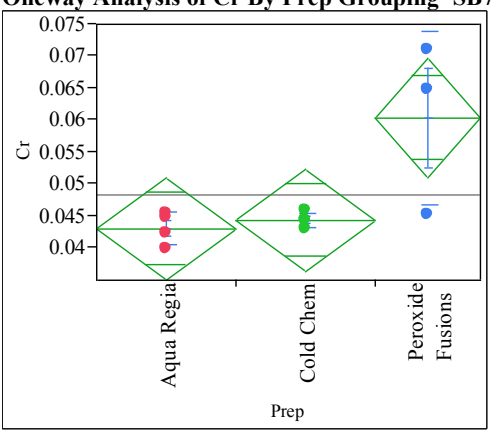

Oneway Anova

Summary of Fit

$\begin{array}{lr}\text { Rsquare } & 0.610576 \\ \text { Adj Rsquare } & 0.51322 \\ \text { Root Mean Square Error } & 0.00696 \\ \text { Mean of Response } & 0.048264 \\ \text { Observations (or Sum Wgts) } & 11\end{array}$

Analysis of Variance

Source DF Sum of Squares Mean Square F Ratio Prob $>$ F $\begin{array}{llllll}\text { Prep } & 2 & 0.00060762 & 0.000304 & 6.2716 & 0.0230\end{array}$ $\begin{array}{llll}\text { Error } & 8 & 0.00038754 & 0.000048\end{array}$

C. Total $10 \quad 0.00099517$

$\begin{array}{lrrrrr}\begin{array}{l}\text { Means for Oneway Anova } \\ \text { Level }\end{array} & & & & \\ \text { Number } & \text { Mean } & \text { Std Error } & \text { Lower 95\% } & \text { Upper 95\% } \\ \text { Aqua Regia } & 4 & 0.043075 & 0.00348 & 0.03505 & 0.05110 \\ \text { Cold Chem } & 4 & 0.044375 & 0.00348 & 0.03635 & 0.05240 \\ \text { Peroxide Fusions } & 3 & 0.060367 & 0.00402 & 0.05110 & 0.06963\end{array}$

Std Error uses a pooled estimate of error variance

Means and Std Deviations

Level Number Mean Std Dev Std Err Mean Lower 95\% Upper 95\%

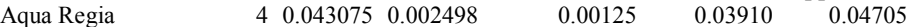

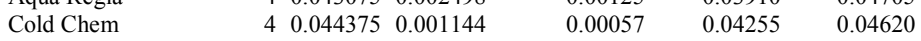

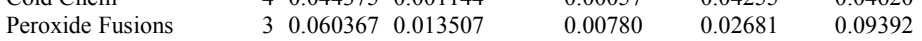

Tests that the Variances are Equal

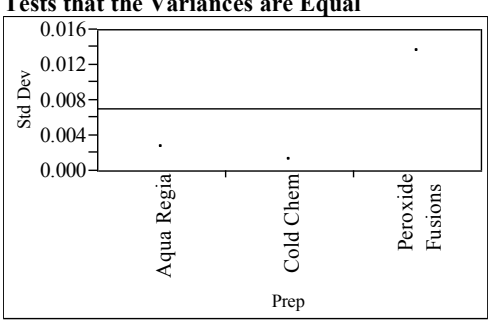

$\begin{array}{lrrrr}\text { Level } & \text { Count } & \text { Std Dev } & \text { MeanAbsDif to Mean } & \text { MeanAbsDif to Median } \\ \text { Aqua Regia } & 4 & 0.0024985 & 0.0019750 & 0.0019750 \\ \text { Cold Chem } & 4 & 0.0011442 & 0.0007250 & 0.0007250 \\ \text { Peroxide Fusions } & 3 & 0.0135072 & 0.0101111 & 0.0107333\end{array}$

$\begin{array}{lrrrr}\text { Test } & \text { F Ratio } & \text { DFNum } & \text { DFDen } & \text { Prob }>\text { F } \\ \text { O'Brien[.5] } & 2.4783 & 2 & 8 & 0.1453 \\ \text { Brown-Forsythe } & 6.3180 & 2 & 8 & 0.0226 \\ \text { Levene } & 10.8086 & 2 & 8 & 0.0053 \\ \text { Bartlett } & 6.1042 & 2 & . & 0.0022\end{array}$

Warning: Small sample sizes. Use Caution.

Welch Anova testing Means Equal, allowing Std Devs Not Equal

F Ratio DFNum DFDen Prob $>$ F

$\begin{array}{llll}2.1970 & 2 & 3.6319 & 0.2370\end{array}$

Means Comparisons

Comparisons for all pairs using Tukey-Kramer HSD

Level Mean

Peroxide Fusions A 0.06036667

Cold Chem $\quad$ B 0.04437500

Aqua Regia $\quad$ B 0.04307500

Levels not connected by same letter are significantly different.
Oneway Analysis of Cu By Prep Grouping=SB7b SRAT, Type=Receipt

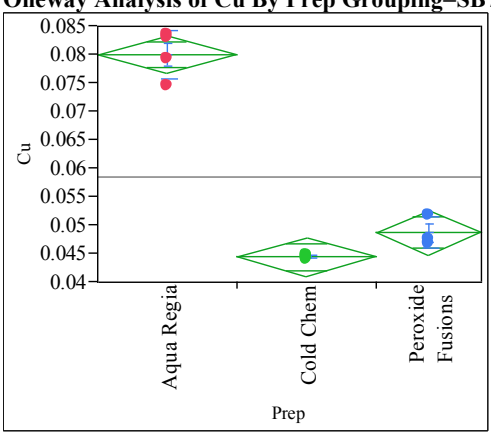

Oneway Anova

Summary of Fit

$\begin{array}{lr}\text { Rsquare } & 0.977384 \\ \text { Adj Rsquare } & 0.97173 \\ \text { Root Mean Square Error } & 0.002912 \\ \text { Mean of Response } & 0.058518 \\ \text { Observations (or Sum Wgts) } & 11\end{array}$

Analysis of Variance

Source DF Sum of Squares Mean Square F Ratio Prob $>$ F

$\begin{array}{llllll}\text { Prep } & 2 & 0.00293150 & 0.001466 & 172.8629 & <.0001\end{array}$

$\begin{array}{llll}\text { Error } & 8 & 0.00006783 & 8.479 \mathrm{e}-6\end{array}$

C. Total $10 \quad 0.00299934$

Means for Oneway Anova

Level Number Mean Std Error Lower 95\% Upper 95\%

$\begin{array}{llllll}\text { Aqua Regia } & 4 & 0.080000 & 0.00146 & 0.07664 & 0.08336\end{array}$

$\begin{array}{llllll}\text { Cold Chem } & 4 & 0.044425 & 0.00146 & 0.04107 & 0.04778\end{array}$

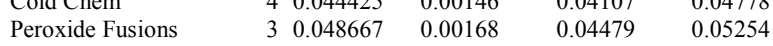

Std Error uses a pooled estimate of error variance

Means and Std Deviations

Level Number Mean Std Dev Std Err Mean Lower 95\% Upper 95\%

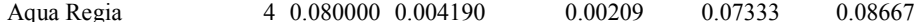

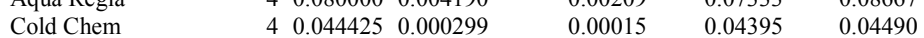

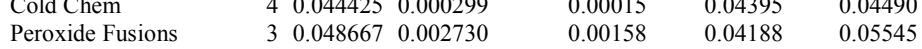

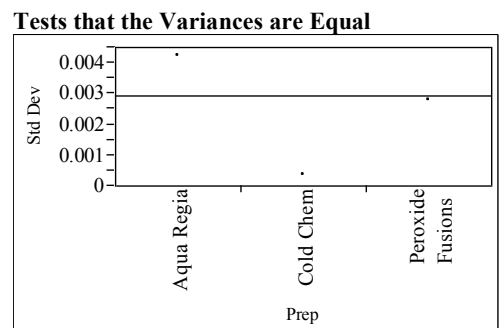

$\begin{array}{lrrrr}\text { Level } & \text { Count } & \text { Std Dev } & \text { MeanAbsDif to Mean } & \text { MeanAbsDif to Median } \\ \text { Aqua Regia } & 4 & 0.0041897 & 0.0032000 & 0.0032000 \\ \text { Cold Chem } & 4 & 0.0002986 & 0.0002250 & 0.0002250 \\ \text { Peroxide Fusions } & 3 & 0.0027301 & 0.0020889 & 0.0018667\end{array}$

Test F Ratio DFNum DFDen Prob $>$ F

$\begin{array}{lrrrr}\text { Test } & \text { F Ratio } & \text { DFNum } & \text { DFDen } & \text { Prob }>\text { F } \\ \text { O'Brien[.5] } & 1.5275 & 2 & 8 & 0.2742 \\ \text { Brown-Forsythe } & 2.7520 & 2 & 8 & 0.1232 \\ \text { Levene } & 5.3045 & 2 & 8 & 0.0342 \\ \text { Bartlett } & 5.0015 & 2 & . & 0.0067\end{array}$

Warning: Small sample sizes. Use Caution.

Welch Anova testing Means Equal, allowing Std Devs Not Equal

F Ratio DFNum DFDen Prob $>$ F

$\begin{array}{llll}121.7612 & 2 & 3.2471 & 0.0009\end{array}$

Means Comparisons

Comparisons for all pairs using Tukey-Kramer HSD

Level

Aqua Regia A $\quad 0.08000000$

Peroxide Fusions $\quad$ B 0.04866667

Cold Chem $\quad$ B 0.04442500

Levels not connected by same letter are significantly different. 
SRNL-STI-2011-00475, REVISION 0

Oneway Analysis of Fe By Prep Grouping=SB7b SRAT, Type=Receipt

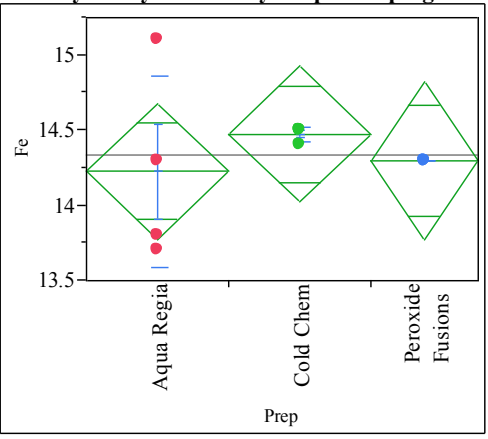

Oneway Anova

Summary of Fit

$\begin{array}{lr}\text { Rsquare } & 0.095539 \\ \text { Adj Rsquare } & -0.13058 \\ \text { Root Mean Square Error } & 0.392906 \\ \text { Mean of Response } & 14.33636 \\ \text { Observations (or Sum Wgts) } & 11\end{array}$

Analysis of Variance

Source DF Sum of Squares Mean Square F Ratio Prob $>$ F

$\begin{array}{lllllll}\text { Prep } & 2 & 0.1304545 & 0.065227 & 0.4225 & 0.6692\end{array}$

$\begin{array}{llll}\text { Error } & 8 & 1.2350000 & 0.154375\end{array}$

C. Total $10 \quad 1.3654545$

Means for Oneway Anova

\begin{tabular}{lrrrrr} 
Level & Number & \multicolumn{1}{c}{ Mean } & Std Error & Lower 95\% & Upper 95\% \\
Aqua Regia & 4 & 14.2250 & 0.19645 & 13.772 & 14.678 \\
Cold Chem & 4 & 14.4750 & 0.19645 & 14.022 & 14.928 \\
Peroxide Fusions & 3 & 14.3000 & 0.22684 & 13.777 & 14.823
\end{tabular}

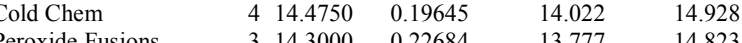

Std Error uses a pooled estimate of error variance

Means and Std Deviations

Level Number Mean Std Dev Std Err Mean Lower 95\% Upper 95\%

$\begin{array}{lrrrrrr}\text { Aqua Regia } & 4 & 14.2250 & 0.639661 & 0.31983 & 13.207 & 15.243\end{array}$

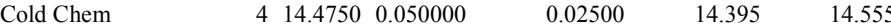

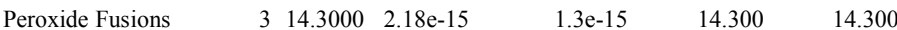

Tests that the Variances are Equal

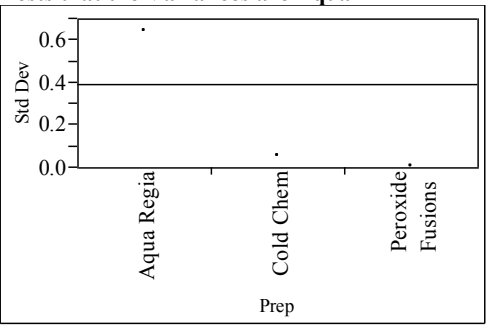

$\begin{array}{lrrrr}\text { Level } & \text { Count } & \text { Std Dev } & \text { MeanAbsDif to Mean } & \text { MeanAbsDif to Median } \\ \text { Aqua Regia } & 4 & 0.6396614 & 0.4750000 & 0.4750000 \\ \text { Cold Chem } & 4 & 0.0500000 & 0.0375000 & 0.0250000 \\ \text { Peroxide Fusions } & 3 & 2.176 \mathrm{e}-15 & 1.776 \mathrm{e}-15 & 0.0000000\end{array}$

$\begin{array}{lrrrr}\text { Test } & \text { F Ratio } & \text { DFNum } & \text { DFDen } & \text { Prob }>\text { F } \\ \text { O'Brien[.5] } & 1.9155 & 2 & 8 & 0.2091 \\ \text { Brown-Forsythe } & 4.7592 & 2 & 8 & 0.0435 \\ \text { Levene } & 6.4377 & 2 & 8 & 0.0216 \\ \text { Bartlett } & 59.9663 & 2 & . & <.0001\end{array}$

Warning: Small sample sizes. Use Caution.

Welch Anova testing Means Equal, allowing Std Devs Not Equal

F Ratio DFNum DFDen Prob $>$ F

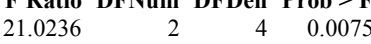

Means Comparisons

Comparisons for all pairs using Tukey-Kramer HSD

Level Mean

Cold Chem A 14.475000

Peroxide Fusions A 14.300000

Aqua Regia A 14.225000

Levels not connected by same letter are significantly different.

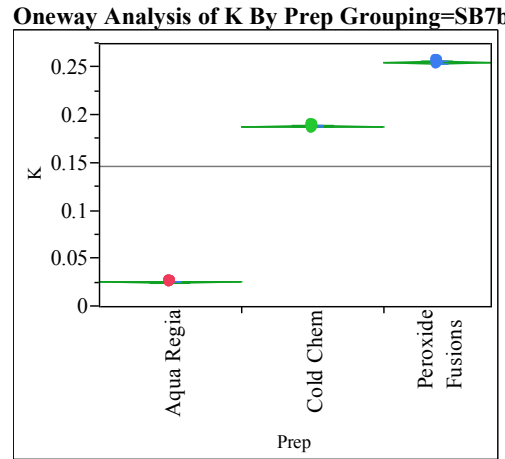

Oneway Anova

Summary of Fit

$\begin{array}{lr}\text { Rsquare } & 0.999945 \\ \text { Adj Rsquare } & 0.999931 \\ \text { Root Mean Square Error } & 0.000833 \\ \text { Mean of Response } & 0.1474 \\ \text { Observations (or Sum Wgts) } & 11\end{array}$

Analysis of Variance

Source DF Sum of Squares Mean Square F Ratio Prob $>$ F

$\begin{array}{llllll}\text { Prep } & 2 & 0.10096466 & 0.050482 & 72680.02 & <.0001\end{array}$

$\begin{array}{llll}\text { Error } & 8 & 0.00000556 & 6.946 \mathrm{e}-7\end{array}$

C. Total $10 \quad 0.10097022$

Means for Oneway Anova

Level Number Mean Std Error Lower 95\% Upper 95\%

$\begin{array}{lllrrr}\text { Aqua Regia } & 4 & 0.025600 & 0.00042 & 0.02464 & 0.02656\end{array}$

$\begin{array}{llllll}\text { Cold Chem } & 4 & 0.188250 & 0.00042 & 0.18729 & 0.18921\end{array}$

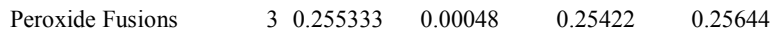

Std Error uses a pooled estimate of error variance

Means and Std Deviations

Level Number Mean Std Dev Std Err Mean Lower 95\% Upper 95\%

$\begin{array}{lllllll}\text { Aqua Regia } & 4 & 0.025600 & 0.000216 & 0.00011 & 0.02526 & 0.02594\end{array}$

$\begin{array}{lllllll}\text { Cold Chem } & 4 & 0.188250 & 0.000957 & 0.00048 & 0.18673 & 0.18977\end{array}$

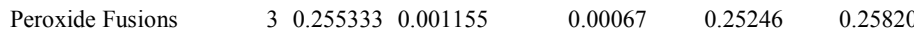

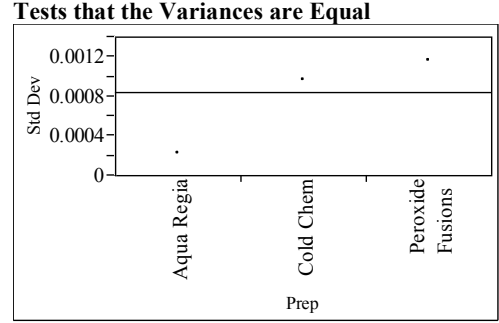

Leve

$\begin{array}{lllll}\text { Cold Chem } & 4 & 0.0009574 & 0.0007500 & 0.0007500 \\ \text { Peroxide Fusions } & 3 & 0.0011547 & 0.0008889 & 0.0006667\end{array}$

$\begin{array}{lrrrr}\text { Test } & \text { F Ratio } & \text { DFNum } & \text { DFDen } & \text { Prob > F } \\ \text { O'Brien[.5] } & 1.3300 & 2 & 8 & 0.3172 \\ \text { Brown-Forsythe } & 0.9462 & 2 & 8 & 0.4277 \\ \text { Levene } & 5.3895 & 2 & 8 & 0.0329 \\ \text { Bartlett } & 2.5410 & 2 & . & 0.0788\end{array}$

Warning: Small sample sizes. Use Caution.

Welch Anova testing Means Equal, allowing Std Devs Not Equal

F Ratio DFNum DFDen Prob $>$ F

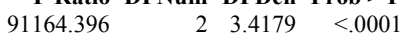

Means Comparisons

Comparisons for all pairs using Tukey-Kramer HSD

Level Mean

Peroxide Fusions A 0.25533333

$\begin{array}{lll}\text { Cold Chem } & \text { B } & 0.18825000\end{array}$

Aqua Regia C 0.02560000

Levels not connected by same letter are significantly different. 
SRNL-STI-2011-00475, REVISION 0

Oneway Analysis of Li By Prep Grouping=SB7b SRAT, Type=Receipt

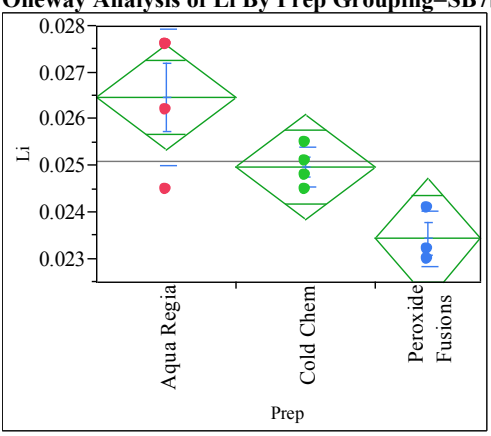

Oneway Anova

Summary of Fit

$\begin{array}{lr}\text { Rsquare } & 0.673347 \\ \text { Adj Rsquare } & 0.591684 \\ \text { Root Mean Square Error } & 0.000984 \\ \text { Mean of Response } & 0.0251 \\ \text { Observations (or Sum Wgts) } & 11\end{array}$

Analysis of Variance

Source DF Sum of Squares Mean Square F Ratio Prob $>$ F $\begin{array}{llllll}\text { Prep } & 2 & 0.00001596 & 7.9792 \mathrm{e}-6 & 8.2454 & 0.0114\end{array}$ $\begin{array}{llll}\text { Error } & 8 & 0.00000774 & 9.6771 \mathrm{e}-7\end{array}$

C. Total $10 \quad 0.00002370$

$\begin{array}{lrrrrr}\begin{array}{l}\text { Means for Oneway Anova } \\ \text { Level }\end{array} & & & & \\ \text { Number } & \text { Mean } & \text { Std Error } & \text { Lower 95\% } & \text { Upper 95\% } \\ \text { Aqua Regia } & 4 & 0.026475 & 0.00049 & 0.02534 & 0.02761 \\ \text { Cold Chem } & 4 & 0.024975 & 0.00049 & 0.02384 & 0.02611 \\ \text { Peroxide Fusions } & 3 & 0.023433 & 0.00057 & 0.02212 & 0.02474\end{array}$

Std Error uses a pooled estimate of error variance

Means and Std Deviations

Level Number Mean Std Dev Std Err Mean Lower 95\% Upper 95\% $\begin{array}{lllllll}\text { Aqua Regia } & 4 & 0.026475 & 0.001473 & 0.00074 & 0.02413 & 0.02882\end{array}$

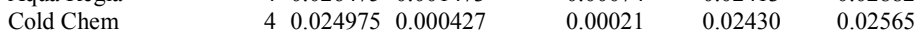

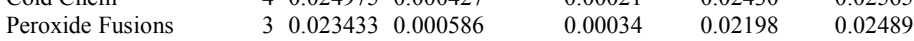

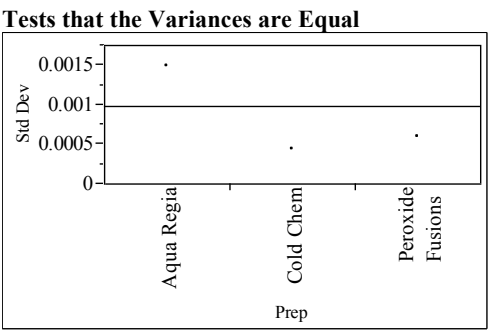

$\begin{array}{lrrrr}\text { Level } & \text { Count } & \text { Std Dev } & \text { MeanAbsDif to Mean } & \text { MeanAbsDif to Median } \\ \text { Aqua Regia } & 4 & 0.0014728 & 0.0011250 & 0.0011250 \\ \text { Cold Chem } & 4 & 0.0004272 & 0.0003250 & 0.0003250 \\ \text { Peroxide Fusions } & 3 & 0.0005859 & 0.0004444 & 0.0004333\end{array}$

$\begin{array}{lrrrr}\text { Test } & \text { F Ratio } & \text { DFNum } & \text { DFDen } & \text { Prob }>\text { F } \\ \text { O'Brien[.5] } & 1.6860 & 2 & 8 & 0.2449 \\ \text { Brown-Forsythe } & 2.2361 & 2 & 8 & 0.1693 \\ \text { Levene } & 3.4896 & 2 & 8 & 0.0814 \\ \text { Bartlett } & 1.9834 & 2 & . & 0.1376\end{array}$

Warning: Small sample sizes. Use Caution.

Welch Anova testing Means Equal, allowing Std Devs Not Equal

F Ratio DFNum DFDen Prob $>$ F

$\begin{array}{llll}9.3019 & 2 & 4.4504 & 0.0257\end{array}$

Means Comparisons

Comparisons for all pairs using Tukey-Kramer HSD

Level Mean

Aqua Regia A $\quad 0.02647500$

Cold Chem A B 0.02497500

Peroxide Fusions B 0.02343333

Levels not connected by same letter are significantly different.
Oneway Analysis of Mo By Prep Grouping=SB7b SRAT, Type=Receipt

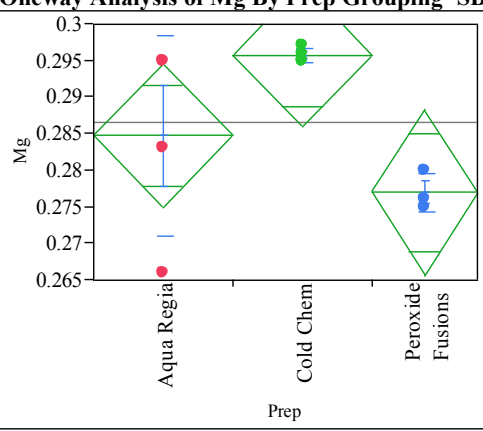

Oneway Anova

Summary of Fit

$\begin{array}{lr}\text { Rsquare } & 0.518046 \\ \text { Adj Rsquare } & 0.397557 \\ \text { Root Mean Square Error } & 0.008526 \\ \text { Mean of Response } & 0.286636 \\ \text { Observations (or Sum Wgts) } & 11\end{array}$

Analysis of Variance

Source DF Sum of Squares Mean Square F Ratio Prob $>$ F

$\begin{array}{llllll}\text { Prep } & 2 & 0.00062505 & 0.000313 & 4.2995 & 0.0540\end{array}$

$\begin{array}{llll}\text { Error } & 8 & 0.00058150 & 0.000073\end{array}$

C. Total $10 \quad 0.00120655$

Means for Oneway Anova

Level Number Mean Std Error Lower 95\% Upper 95\%

$\begin{array}{llllll}\text { Aqua Regia } & 4 & 0.284750 & 0.00426 & 0.27492 & 0.29458\end{array}$

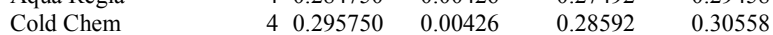

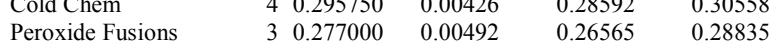

Std Error uses a pooled estimate of error variance

Means and Std Deviations

Level Number Mean Std Dev Std Err Mean Lower 95\% Upper 95\%

$\begin{array}{lllllll}\text { Aqua Regia } & 4 & 0.284750 & 0.013720 & 0.00686 & 0.26292 & 0.30658\end{array}$

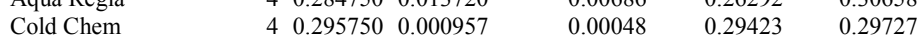

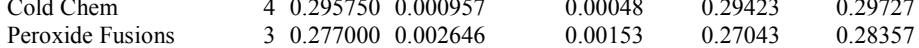

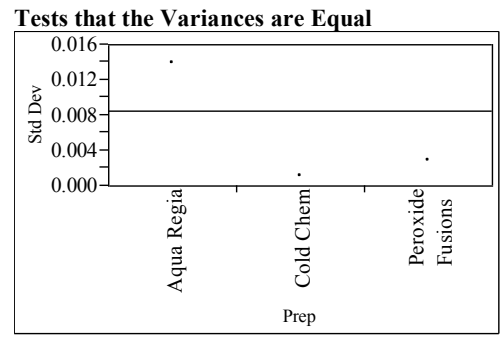

$\begin{array}{lrrrr}\text { Level } & \text { Count } & \text { Std Dev } & \text { MeanAbsDif to Mean } & \text { MeanAbsDif to Median } \\ \text { Aqua Regia } & 4 & 0.0137204 & 0.0102500 & 0.0102500 \\ \text { Cold Chem } & 4 & 0.0009574 & 0.0007500 & 0.0007500 \\ \text { Peroxide Fusions } & 3 & 0.0026458 & 0.0020000 & 0.0020000\end{array}$

Test $\quad$ F Ratio DFNum DFDen Prob $>$ F

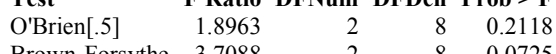

Brown-Forsythe $3.7088 \quad 2 \quad 80.0725$

$\begin{array}{lllll}\text { Levene } & 5.6388 & 2 & 8 & 0.0297\end{array}$

$\begin{array}{lllll}\text { Bartlett } & 6.3672 & 2 & . & 0.0017\end{array}$

Warning: Small sample sizes. Use Caution.

Welch Anova testing Means Equal, allowing Std Devs Not Equal

F Ratio DFNum DFDen Prob $>$ F

$\begin{array}{llll}58.5623 & 2 & 3.5639 & 0.0019\end{array}$

Means Comparisons

Comparisons for all pairs using Tukey-Kramer HSD

Leve Mean

Cold Chem A $\quad 0.29575000$

Aqua Regia A B 0.28475000

Peroxide Fusions B 0.27700000

Levels not connected by same letter are significantly different. 
SRNL-STI-2011-00475, REVISION 0

Oneway Analysis of Mn By Prep Grouping $=$ SB7b SRAT, Type $=$ Receipt

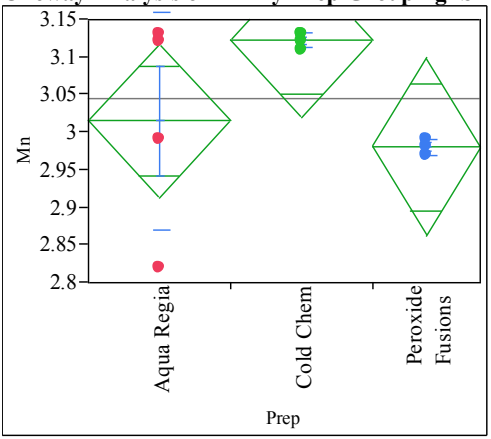

Oneway Anova

Summary of Fit

$\begin{array}{lr}\text { Rsquare } & 0.388701 \\ \text { Adj Rsquare } & 0.235877 \\ \text { Root Mean Square Error } & 0.089005 \\ \text { Mean of Response } & 3.044545 \\ \text { Observations (or Sum Wgts) } & 11\end{array}$

Analysis of Variance

Source DF Sum of Squares Mean Square F Ratio Prob $>$ F

$\begin{array}{llllll}\text { Prep } & 2 & 0.04029773 & 0.020149 & 2.5434 & 0.1396\end{array}$

$\begin{array}{llll}\text { Error } & 8 & 0.06337500 & 0.007922\end{array}$

C. Total $10 \quad 0.10367273$

Means for Oneway Anova

$\begin{array}{lrrrrr}\text { Level } & \text { Number } & \text { Mean } & \text { Std Error } & \text { Lower 95\% } & \text { Upper 95\% } \\ \text { Aqua Regia } & 4 & 3.01500 & 0.04450 & 2.9124 & 3.1176 \\ \text { Cold Chem } & 4 & 3.12250 & 0.04450 & 3.0199 & 3.2251 \\ \text { Peroxide Fusions } & 3 & 2.98000 & 0.05139 & 2.8615 & 3.0985\end{array}$

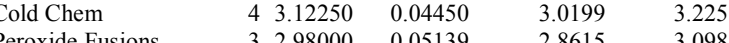

Std Error uses a pooled estimate of error variance

Means and Std Deviations

Level Number Mean Std Dev Std Err Mean Lower 95\% Upper 95\%

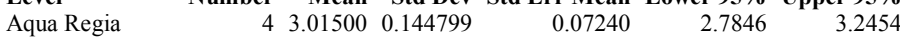

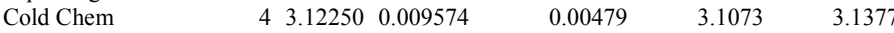

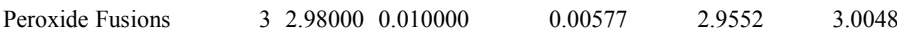

Tests that the Variances are Equal

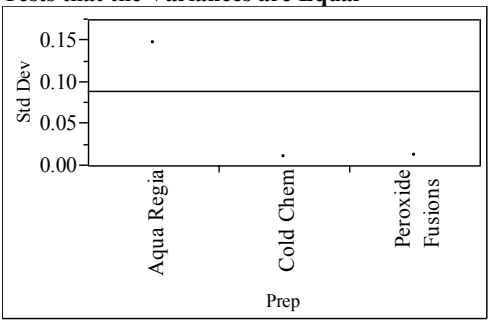

$\begin{array}{lrrrr}\text { Level } & \text { Count } & \text { Std Dev } & \text { MeanAbsDif to Mean } & \text { MeanAbsDif to Median } \\ \text { Aqua Regia } & 4 & 0.1447987 & 0.1100000 & 0.1100000 \\ \text { Cold Chem } & 4 & 0.0095743 & 0.0075000 & 0.0075000 \\ \text { Peroxide Fusions } & 3 & 0.0100000 & 0.0066667 & 0.0100000\end{array}$

Test F Ratio DFNum DFDen Prob $>$ F

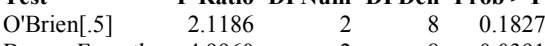

Brown-Forsythe $4.9960 \quad 2 \quad 80.0391$

$\begin{array}{lllll}\text { Levene } & 7.3700 & 2 & 8 & 0.0153\end{array}$

$\begin{array}{lllll}\text { Bartlett } & 8.1808 & 2 & . & 0.0003\end{array}$

Warning: Small sample sizes. Use Caution.

Welch Anova testing Means Equal, allowing Std Devs Not Equal

F Ratio DFNum DFDen Prob $>$ F

$\begin{array}{llll}158.4136 & 2 & 4.7318 & <.0001\end{array}$

Means Comparisons

Comparisons for all pairs using Tukey-Kramer HSD

Level

Aqua Regia A 3.0150000

Peroxide Fusions A 2.9800000

Levels not connected by same letter are significantly different.
Oneway Analysis of Na By Prep Grouping=SB7b SRAT, Type=Receipt

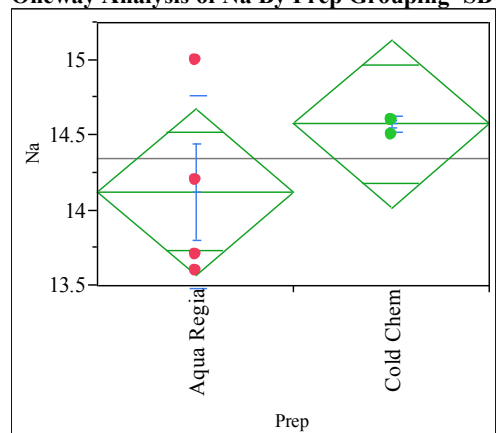

Missing Rows 3

Oneway Anova

Summary of Fit

$\begin{array}{lr}\text { Rsquare } & 0.246951 \\ \text { Adj Rsquare } & 0.121443 \\ \text { Root Mean Square Error } & 0.453689 \\ \text { Mean of Response } & 14.35 \\ \text { Observations (or Sum Wgts) } & 8\end{array}$

Analysis of Variance

Source DF Sum of Squares Mean Square F Ratio Prob $>$ F

$\begin{array}{llllll}\text { Prep } & 1 & 0.4050000 & 0.405000 & 1.9676 & 0.2103\end{array}$

$\begin{array}{llll}\text { Error } & 6 & 1.2350000 & 0.205833\end{array}$

C. Total $7 \quad 1.6400000$

Means for Oneway Anova

Level Number Mean Std Error Lower 95\% Upper 95\%

$\begin{array}{llrrrr}\text { Aqua Regia } & 4 & 14.1250 & 0.22684 & 13.570 & 14.680\end{array}$

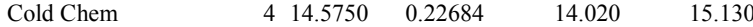

Peroxide Fusion

Std Error uses a pooled estimate of error variance

Means and Std Deviations

Level Number Mean Std Dev Std Err Mean Lower 95\% Upper 95\%

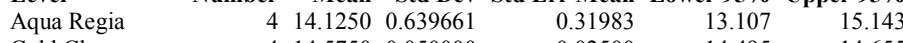

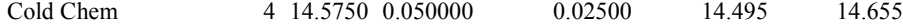

Peroxide Fusions

Tests that the Variances are Equal

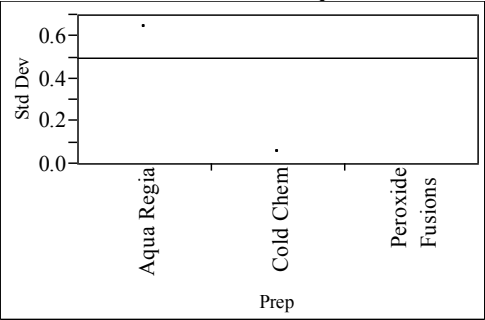

Level Count Std Dev MeanAbsDif to Mean MeanAbsDif to Median

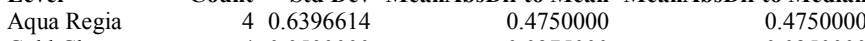

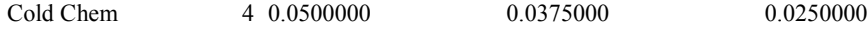

$\begin{array}{llll}\text { Peroxide Fusions } & 0 & 0.0000000 & 0.0000000\end{array}$

Test F Ratio DFNum DFDen Prob $>$ F

$\begin{array}{lllll}\text { O'Brien[.5] } & 2.2457 & 1 & 6 & 0.1846\end{array}$

Brown-Forsythe $\quad 5.3407 \quad 1 \quad 60.0602$

$\begin{array}{lllll}\text { Levene } & 7.0268 & 1 & 6 & 0.0380\end{array}$

$\begin{array}{llllll}\text { Bartlett } & 9.5753 & 1 & 0.0020\end{array}$

Warning: Small sample sizes. Use Caution.

Welch Anova testing Means Equal, allowing Std Devs Not Equal

F Ratio DFNum DFDen Prob $>$ F

$\begin{array}{rrrr}1.9676 & 1 & 3.0367 & 0.2542\end{array}$ 
SRNL-STI-2011-00475, REVISION 0

Oneway Analysis of Ni By Prep Grouping=SB7b SRAT, Type=Receipt

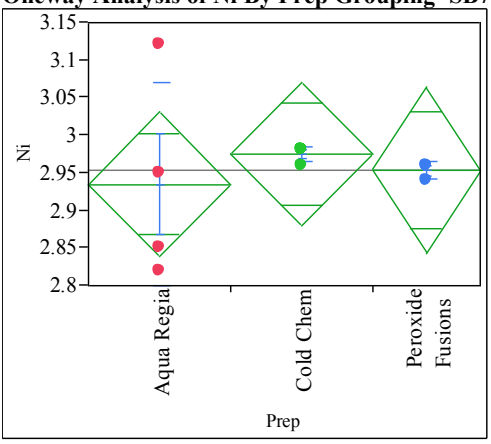

Oneway Anova

Summary of Fit

$\begin{array}{lr}\text { Rsquare } & 0.054643 \\ \text { Adj Rsquare } & -0.1817 \\ \text { Root Mean Square Error } & 0.083267 \\ \text { Mean of Response } & 2.954545 \\ \text { Observations (or Sum Wgts) } & 11\end{array}$

Analysis of Variance

Source DF Sum of Squares Mean Square F Ratio Prob $>$ F

$\begin{array}{llllll}\text { Prep } & 2 & 0.00320606 & 0.001603 & 0.2312 & 0.7987\end{array}$

$\begin{array}{llll}\text { Error } & 8 & 0.05546667 & 0.006933\end{array}$

$\begin{array}{lll}\text { C. Total } & 10 & 0.05867273\end{array}$

Means for Oneway Anova

\begin{tabular}{|c|c|c|c|c|c|}
\hline & Number & Mes & Std Error & Lower 95\% & \\
\hline egia & & 2.93500 & 0.04163 & 2.8390 & \\
\hline & & 2.9710 & 0.04163 & 2.8790 & \\
\hline oxide Fusions & & 2.95333 & 0.04807 & 2.8425 & \\
\hline
\end{tabular}

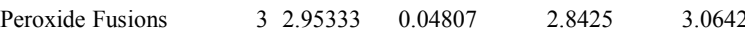

Std Error uses a pooled estimate of error variance

Means and Std Deviations

Level Number Mean Std Dev Std Err Mean Lower 95\% Upper 95\%

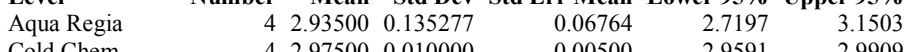

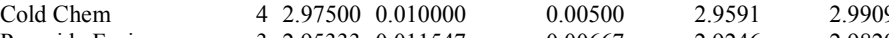

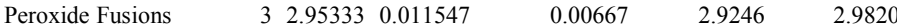

Tests that the Variances are Equal

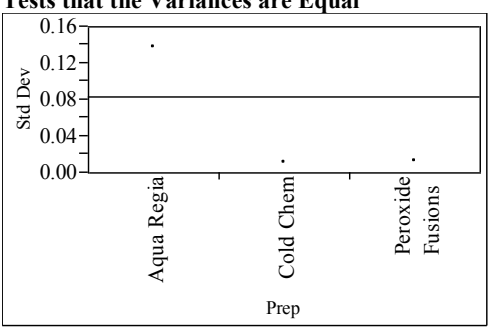

$\begin{array}{lrrrr}\text { Level } & \text { Count } & \text { Std Dev } & \text { MeanAbsDif to Mean } & \text { MeanAbsDif to Median } \\ \text { Aqua Regia } & 4 & 0.1352775 & 0.1000000 & 0.1000000 \\ \text { Cold Chem } & 4 & 0.0100000 & 0.0075000 & 0.0050000 \\ \text { Peroxide Fusions } & 3 & 0.0115470 & 0.0088889 & 0.0066667\end{array}$

$\begin{array}{lrrrr}\text { Test } & \text { F Ratio } & \text { DFNum } & \text { DFDen } & \text { Prob }>\text { F } \\ \text { O'Brien[.5] } & 1.8793 & 2 & 8 & 0.2143 \\ \text { Brown-Forsythe } & 4.4452 & 2 & 8 & 0.0503 \\ \text { Levene } & 5.7325 & 2 & 8 & 0.0285 \\ \text { Bartlett } & 7.5441 & 2 & . & 0.0005\end{array}$

Warning: Small sample sizes. Use Caution.

Welch Anova testing Means Equal, allowing Std Devs Not Equal

F Ratio DFNum DFDen Prob $>$ F

$\begin{array}{llll}3.0503 & 2 & 4.5949 & 0.1435\end{array}$

Means Comparisons

Comparisons for all pairs using Tukey-Kramer HSD

Level

Mean

Cold Chem A 2.9750000

Peroxide Fusions A 2.9533333

Aqua Regia A 2.9350000

Levels not connected by same letter are significantly different.
Oneway Analysis of Si By Prep Grouping=SB7b SRAT, Type=Receipt

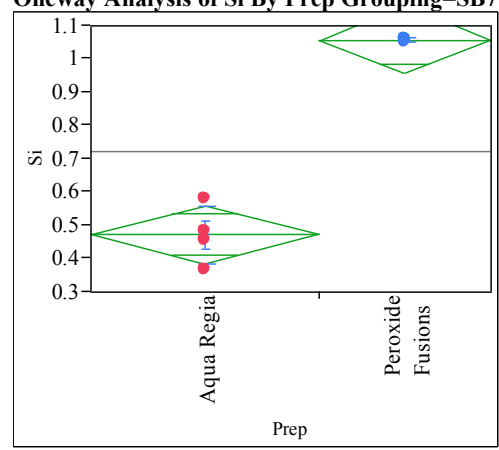

Missing Rows 4

Oneway Anova

Summary of Fit

$\begin{array}{lr}\text { Rsquare } & 0.962297 \\ \text { Adj Rsquare } & 0.954756 \\ \text { Root Mean Square Error } & 0.067793 \\ \text { Mean of Response } & 0.722429 \\ \text { Observations (or Sum Wgts) } & 7\end{array}$

Analysis of Variance

Source DF Sum of Squares Mean Square F Ratio Prob $>$ F

$\begin{array}{lllllll}\text { Prep } & 1 & 0.58650430 & 0.586504 & 127.6151<.0001\end{array}$

$\begin{array}{llll}\text { Error } & 5 & 0.02297942 & 0.004596\end{array}$

C. Total $6 \quad 0.60948371$

Means for Oneway Anova

$\begin{array}{lllll}\text { Level Number } & \text { Mean Std Error Lower 95\% } & \text { Upper 95\% }\end{array}$

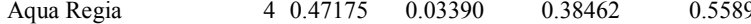

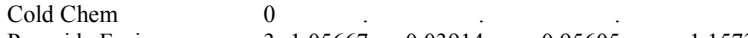

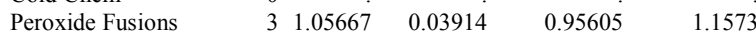

Std Error uses a pooled estimate of error variance

Means and Std Deviations

Level Number Mean Std Dev Std Err Mean Lower 95\% Upper 95\%

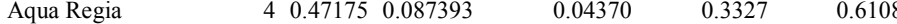

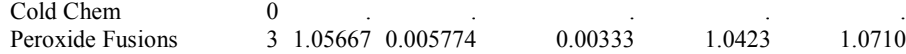

Tests that the Variances are Equal

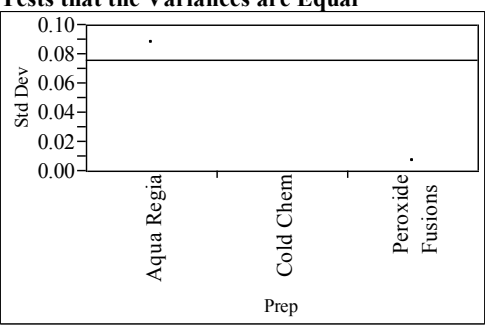

Level Count Std Dev MeanAbsDif to Mean MeanAbsDif to Median

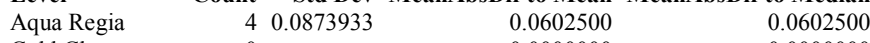

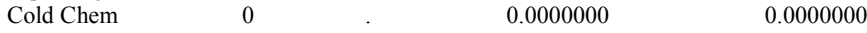

$\begin{array}{llll}\text { Peroxide Fusions } & 3 & 0.0057735 & 0.0044444\end{array}$

Test F Ratio DFNum DFDen Prob $>$ F

$\begin{array}{lllll}\text { O'Brien[.5] } & 1.4622 & 1 & 5 & 0.2806\end{array}$

$\begin{array}{lllll}\text { Brown-Forsythe } & 3.2747 & 1 & 5 & 0.1301\end{array}$

$\begin{array}{lllll}\text { Levene } & 3.1779 & 1 & 5 & 0.1347\end{array}$

$\begin{array}{llllll}\text { Bartlett } & 6.8771 & 1 & 0.0087\end{array}$

Warning: Small sample sizes. Use Caution.

Welch Anova testing Means Equal, allowing Std Devs Not Equal

F Ratio DFNum DFDen Prob $>$ F

$\begin{array}{rrrr}178.1444 & 1 & 3.0349 & 0.0009\end{array}$ 
SRNL-STI-2011-00475, REVISION 0

Oneway Analysis of Th By Prep Grouping=SB7b SRAT, Type=Receipt

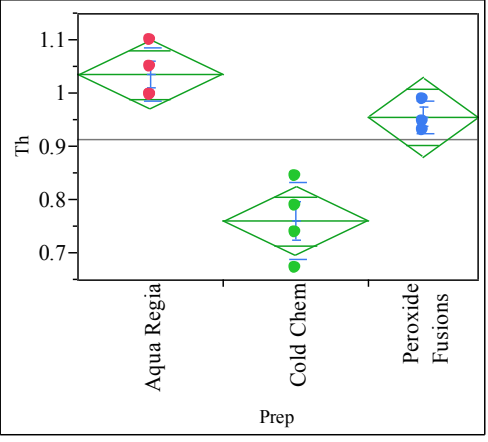

Oneway Anova

Summary of Fit

$\begin{array}{lr}\text { Rsquare } & 0.863068 \\ \text { Adj Rsquare } & 0.828835 \\ \text { Root Mean Square Error } & 0.056129 \\ \text { Mean of Response } & 0.914182 \\ \text { Observations (or Sum Wgts) } & 11\end{array}$

Observations (or Sum Wgts)

Analysis of Variance

Source DF Sum of Squares Mean Square F Ratio Prob $>$ F

$\begin{array}{lllllll}\text { Prep } & 2 & 0.15885422 & 0.079427 & 25.2115 & 0.0004\end{array}$

$\begin{array}{llll}\text { Error } & 8 & 0.02520342 & 0.003150\end{array}$

C. Total $10 \quad 0.18405764$

Means for Oneway Anova

$\begin{array}{lrrrrr}\text { Level } & \text { Number } & \text { Mean } & \text { Std Error } & \text { Lower 95\% } & \text { Upper 95\% } \\ \text { Aqua Regia } & 4 & 1.03600 & 0.02806 & 0.97128 & 1.1007 \\ \text { Cold Chem } & 4 & 0.76075 & 0.02806 & 0.69603 & 0.8255 \\ \text { Peroxide Fusions } & 3 & 0.95633 & 0.03241 & 0.88161 & 1.0311\end{array}$

Std Error uses a pooled estimate of error variance

Means and Std Deviations

Level Number Mean Std Dev Std Err Mean Lower 95\% Upper 95\%

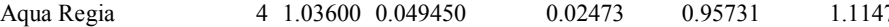

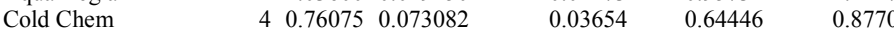

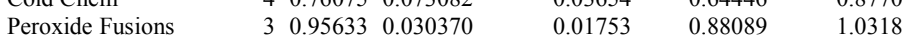

Tests that the Variances are Equal

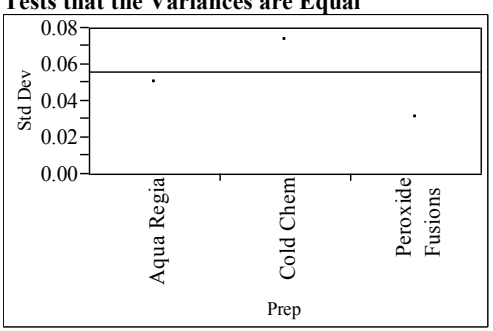

$\begin{array}{lrrrr}\text { Level } & \text { Count } & \text { Std Dev } & \text { MeanAbsDif to Mean } & \text { MeanAbsDif to Median } \\ \text { Aqua Regia } & 4 & 0.0494503 & 0.0390000 & 0.0390000 \\ \text { Cold Chem } & 4 & 0.0730816 & 0.0552500 & 0.0552500 \\ \text { Peroxide Fusions } & 3 & 0.0303699 & 0.0224444 & 0.0253333\end{array}$

$\begin{array}{llll}\text { Peroxide Fusions } & 3 & 0.0303699 & 0.0224444\end{array}$

$\begin{array}{lrrrr}\text { Test } & \text { F Ratio } & \text { DFNum } & \text { DFDen } & \text { Prob > F } \\ \text { O'Brien[.5] } & 0.9312 & 2 & 8 & 0.4329 \\ \text { Brown-Forsythe } & 1.0278 & 2 & 8 & 0.4006 \\ \text { Levene } & 1.3762 & 2 & 8 & 0.3064 \\ \text { Bartlett } & 0.6958 & 2 & . & 0.4987\end{array}$

Warning: Small sample sizes. Use Caution.

Welch Anova testing Means Equal, allowing Std Devs Not Equal

F Ratio DFNum DFDen Prob $>$ F

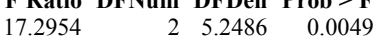

Means Comparisons

Comparisons for all pairs using Tukey-Kramer HSD

Level Mean

Aqua Regia A 1.0360000

Peroxide Fusions A 0.9563333

Cold Chem B 0.7607500

Levels not connected by same letter are significantly different.

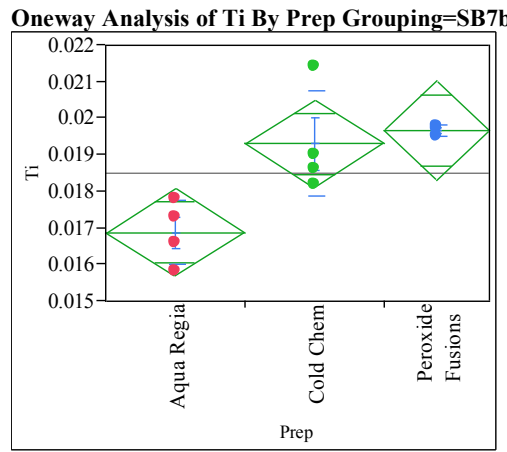

Oneway Anova

Summary of Fit

Rsquare

Adj Rsquare $\quad 0.58615$

Root Mean Square Error $\quad 0.001032$

Mean of Response $\quad 0.018518$

Observations (or Sum Wgts) 11

Analysis of Variance

Source DF Sum of Squares Mean Square F Ratio Prob $>$ F

$\begin{array}{llllll}\text { Prep } & 2 & 0.00001720 & 8.6011 \mathrm{e}-6 & 8.0817 & 0.0120\end{array}$

$\begin{array}{llll}\text { Error } & 8 & 0.00000851 & 1.0643 \mathrm{e}-6\end{array}$

C. Total $10 \quad 0.00002572$

Means for Oneway Anova

Level Number Mean Std Error Lower 95\% Upper 95\%

$\begin{array}{llllll}\text { Aqua Regia } & 4 & 0.016875 & 0.00052 & 0.01569 & 0.01806\end{array}$

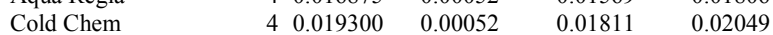

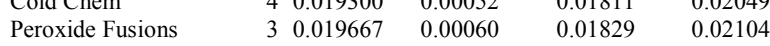

Std Error uses a pooled estimate of error variance

Means and Std Deviations

Level Number Mean Std Dev Std Err Mean Lower 95\% Upper 95\%

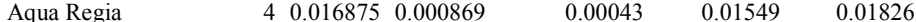

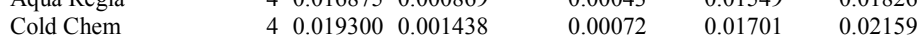

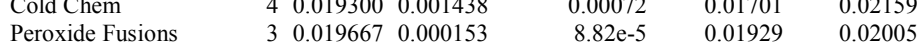

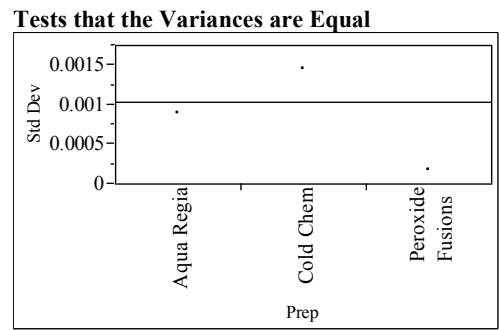

Leve

Cold Chr

Count Std Dev MeanAbsDif to Mean MeanAbsDif to Median

Test F Ratio DFNum DFDen Prob $>$ F

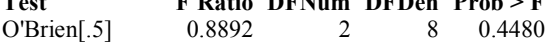

$\begin{array}{lllll}\text { Brown-Forsythe } & 0.9336 & 2 & 8 & 0.4321\end{array}$

$\begin{array}{lllll}\text { Levene } & 2.6963 & 2 & 8 & 0.1273\end{array}$

$\begin{array}{lllll}\text { Bartlett } & 2.8442 & 2 & . & 0.0582\end{array}$

Warning: Small sample sizes. Use Caution.

Welch Anova testing Means Equal, allowing Std Devs Not Equal

F Ratio DFNum DFDen Prob $>$ F

$\begin{array}{llll}17.1540 & 2 & 4.2116 & 0.0095\end{array}$

Means Comparisons

Comparisons for all pairs using Tukey-Kramer HSD

Level

Peroxide Fusions A 0.01966667

Cold Chem A 0.01930000

Aqua Regia B 0.01687500

Levels not connected by same letter are significantly different. 
SRNL-STI-2011-00475, REVISION 0

Oneway Analysis of U By Prep Grouping=SB7b SRAT, Type=Receipt

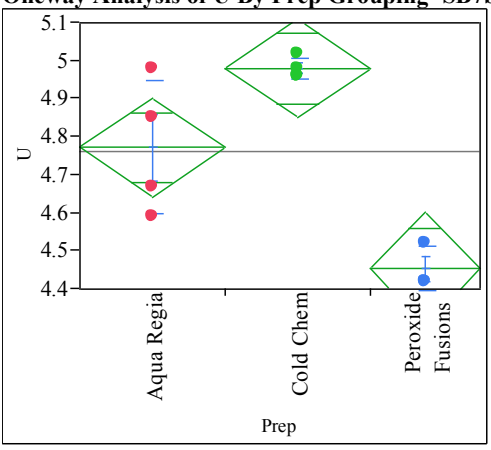

Oneway Anova

Summary of Fit

$\begin{array}{lr}\text { Rsquare } & 0.823719 \\ \text { Adj Rsquare } & 0.779649 \\ \text { Root Mean Square Error } & 0.112884 \\ \text { Mean of Response } & 4.760909 \\ \text { Observations (or Sum Wgts) } & 11\end{array}$

Analysis of Variance

Source DF Sum of Squares Mean Square F Ratio Prob $>$ F

$\begin{array}{llllll}\text { Prep } & 2 & 0.47634924 & 0.238175 & 18.6911 & 0.0010\end{array}$

$\begin{array}{llll}\text { Error } & 8 & 0.10194167 & 0.012743\end{array}$

C. Total $10 \quad 0.57829091$

Means for Oneway Anova

Level Number Mean Std Error Lower 95\% Upper 95\%

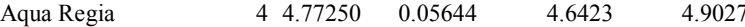

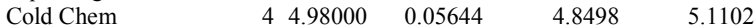

$\begin{array}{lllll}\text { Peroxide Fusions } & 3 & 4.45333 & 0.06517 & 4.3030\end{array} 4.6036$

Std Error uses a pooled estimate of error variance

Means and Std Deviations

Level Number Mean Std Dev Std Err Mean Lower 95\% Upper 95\%

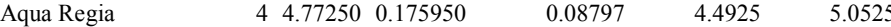

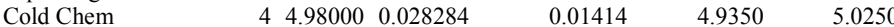

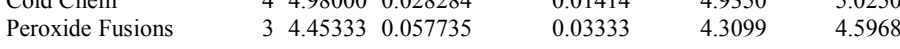

Tests that the Variances are Equal

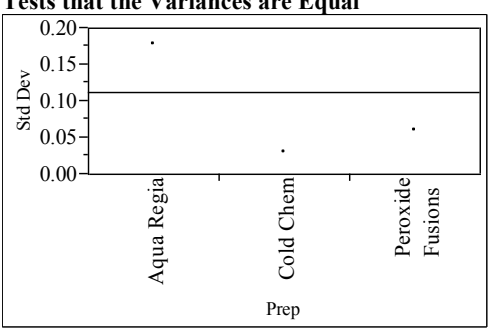

$\begin{array}{lrrrr}\text { Level } & \text { Count } & \text { Std Dev } & \text { MeanAbsDif to Mean } & \text { MeanAbsDif to Median } \\ \text { Aqua Regia } & 4 & 0.1759498 & 0.1425000 & 0.1425000 \\ \text { Cold Chem } & 4 & 0.0282843 & 0.0200000 & 0.0200000 \\ \text { Peroxide Fusions } & 3 & 0.0577350 & 0.0444444 & 0.0333333\end{array}$

$\begin{array}{lrrrr}\text { Test } & \text { F Ratio } & \text { DFNum } & \text { DFDen } & \text { Prob }>\text { F } \\ \text { O'Brien[.5] } & 3.2165 & 2 & 8 & 0.0944 \\ \text { Brown-Forsythe } & 6.9551 & 2 & 8 & 0.0178 \\ \text { Levene } & 9.9973 & 2 & 8 & 0.0067 \\ \text { Bartlett } & 3.5460 & 2 & . & 0.0288\end{array}$

Warning: Small sample sizes. Use Caution.

Welch Anova testing Means Equal, allowing Std Devs Not Equal

F Ratio DFNum DFDen Prob $>$ F

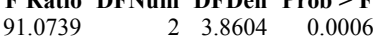

Means Comparisons

Comparisons for all pairs using Tukey-Kramer HSD

Level

Cold Chem Mean

Aqua Regia $\quad$ A 4.7725000

Peroxide Fusions B 4.4533333

Levels not connected by same letter are significantly different.
Oneway Analysis of $\mathrm{Zr}$ By Prep Grouping=SB7b SRAT, Type=Receipt

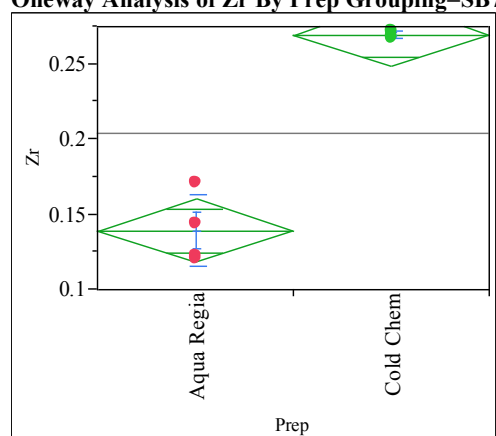

Missing Rows 3

Oneway Anova

Summary of Fit

$\begin{array}{lr}\text { Rsquare } & 0.951867 \\ \text { Adj Rsquare } & 0.943845 \\ \text { Root Mean Square Error } & 0.01691 \\ \text { Mean of Response } & 0.204375 \\ \text { Observations (or Sum Wgts) } & 8\end{array}$

Analysis of Variance

Source DF Sum of Squares Mean Square F Ratio Prob $>$ F

$\begin{array}{lllllll}\text { Prep } & 1 & 0.03393013 & 0.033930 & 118.6541 & <.0001\end{array}$

$\begin{array}{llll}\text { Error } & 6 & 0.00171575 & 0.000286\end{array}$

C. Total $7 \quad 0.03564588$

Means for Oneway Anova

Level Number Mean Std Error Lower 95\% Upper 95\%

$\begin{array}{llrrrr}\text { Aqua Regia } & 4 & 0.139250 & 0.00846 & 0.11856 & 0.15994\end{array}$

$\begin{array}{llllll}\text { Cold Chem } & 4 & 0.269500 & 0.00846 & 0.24881 & 0.29019\end{array}$

Peroxide Fusion

Std Error uses a pooled estimate of error variance

Means and Std Deviations

Level Number Mean Std Dev Std Err Mean Lower 95\% Upper 95\%

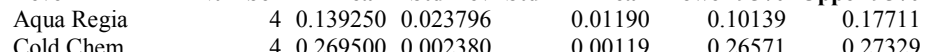

$\begin{array}{llll}4 & 0.269500 & 0.002380\end{array}$

0.00119

0.2657

Tests that the Variances are Equal

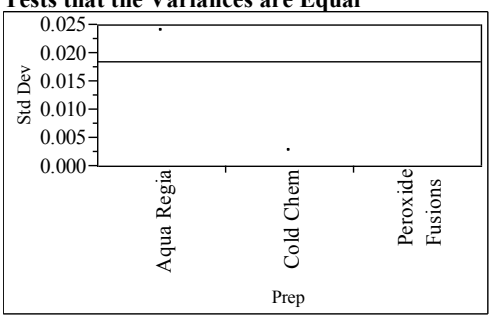

Leve

Aqua Regia

Count Std Dev MeanAbsDif to Mean MeanAbsDif to Median

0.0182500

Test F Ratio DFNum DFDen Prob $>$ F

$\begin{array}{lrrrr}\text { Test } & \text { F Ratio } & \text { DFNum } & \text { DFDen } & \text { Prob > F } \\ \text { O'Brien[.5] } & 2.6050 & 1 & 6 & 0.1577 \\ \text { Brown-Forsythe } & 6.0501 & 1 & 6 & 0.0491 \\ \text { Levene } & 8.6224 & 1 & 6 & 0.0261 \\ \text { Bartlett } & 8.3264 & 1 & . & 0.0039\end{array}$

Warning: Small sample sizes. Use Caution.

Welch Anova testing Means Equal, allowing Std Devs Not Equal

F Ratio DFNum DFDen Prob $>$ F

$\begin{array}{llll}118.6541 & 1 & 3.06 & 0.0015\end{array}$ 
Distribution

M.J. Barnes, 773-A

J.M. Bricker, 704-27S

C.J. Coleman, 773-A

T.B. Edwards, 773-42A

M.T. Feller, 704-28S

T.L. Fellinger, 704-26S

C.M. Gregory, 773-A

C.C. Herman, 999-W

E.W. Holtzscheiter, 704-15S

J.F. Iaukea, 704-30S

P.L. Lee, 773-A

S.L. Marra, 773-A

R.T. McNew, 704-S

R.N. Mahannah, 704-28S

A.B. Osteen, 704-28S

J.E. Occhipinti, 704-S

J.M. Pareizs, 773-A

D.K. Peeler, 999-W

H.M. Pittman, 704-27S

J.W. Ray, 704-S

D.C. Sherburne, 704-S

A.V. Staub, 704-27S

M.E. Stone, 999-W

B.J. Wiedenman, 773-A 